\title{
MIOCENE WATERFOWL AND OTHER BIRDS FROM CENTRAL OTAGO, NEW ZEALAND
}

\section{T. H. Worthy*}

Darling Building, DP 418, Dept. of Earth and Environmental Sciences, The University of Adelaide, SA 5005, Australia

\section{A. J. D. Tennyson}

Museum of New Zealand Te Papa Tongarewa, P.O. Box 467, Wellington, New Zealand

\section{Jones}

Institute of Geological and Nuclear Sciences, P.O. Box 30368, Lower Hutt, New Zealand

\section{J. A. McNamara}

South Australian Museum, North Terrace, Adelaide, Australia

\section{B. J. Douglas}

14 Jubilee Street, Dunedin, New Zealand

SYNOPSIS Abundant fossil bird bones from the lower Bannockburn Formation, Manuherikia Group, an Early-Middle Miocene lacustrine deposit, 16-19 Ma, from Otago in New Zealand, reveal the "St Bathans Fauna" (new name), a first Tertiary avifauna of land and freshwater birds from New Zealand. At least 23 species of birds are represented by bones, and probable moa, Aves: Dinornithiformes, by eggshell. Anatids dominate the fauna with four genera and five species described as new: a sixth and largest anatid species is represented by just one bone. This is the most diverse Early-Middle Miocene duck fauna known worldwide. Among ducks, two species of dendrochenines are most numerous in the fauna, but a tadornine is common as well. A diving petrel (Pelecanoididae: Pelecanoides) is described, so extending the geological range of this genus worldwide from the Pliocene to the Middle Miocene, at least. The remaining 16 taxa are left undescribed but include: a large species of gull (Laridae); two small waders (Charadriiformes, genus indet.), the size of Charadrius bicinctus and Calidris ruficollis, respectively; a gruiform represented by one specimen similar to Aptornis; abundant rail (Rallidae) bones, including a common flightless rail and a rarer slightly larger taxon, about the size of Gallirallus philippensis; an ?eagle (Accipitridae); a pigeon (Columbidae); three parrots (Psittacidae); an owlet nightjar (Aegothelidae: Aegotheles sp.); a swiftlet (Apodidae: Collocalia sp.); and three passerine taxa, of which the largest is a member of the Cracticidae. The absence of some waterbirds, such as anserines (including swans), grebes (Podicipedidae) and shags (Phalacrocoracidae), among the abundant bones, indicates their probable absence from New Zealand in the Early-Middle Miocene.

KEY WORDS Avifauna, fossils, new taxa, Anatidae, lacustrine, Early-Middle Miocene, New Zealand

\section{Contents}

Introduction 3

Geological and palaeoenvironmental setting

Methods $\quad 4$

Abbreviations $\quad 4$

Institutions $\quad 4$

Skeletal elements and descriptive terms used $\quad 4$

Measurements $\quad 4$

Comparative material $\quad 6$

$\begin{array}{ll}\text { Taxonomic issues } & \mathbf{7}\end{array}$

$\begin{array}{ll}\text { Taphonomy } & 7\end{array}$

\footnotetext{
*Corresponding author. E-mail address: trevor.worthy@adelaide.edu.au.
} 
Systematic palaeontology

Order Procellariiformes Fürbringer, 1888

Family Pelecanoididae Gray, 1871

Genus Pelecanoides Lacépède, $1799 \quad 8$

Pelecanoides miokuaka sp. nov.

Order Anseriformes Wagler, 1831

Family Anatidae Leach, $1820 \quad 8$

Subfamily Dendrocheninae Livezey \& Martin, 1988

Genus Manuherikia gen. nov. $\quad 9$

Manuherikia lacustrina gen. et sp. nov. $\quad 10$

Manuherikia minuta gen. et sp. nov. $\quad 12$

$\begin{array}{ll}\text { Subfamily Tadorninae Reichenbach, 1849-1850 } & 14\end{array}$

Tribe Tadornini (Reichenbach, 1849-1850) 14

Genus Miotadorna gen. nov. 14

Miotadorna sanctibathansi gen. et sp. nov. $\quad 14$

$\begin{array}{ll}\text { Anatidae, Subfamily undetermined } & 17\end{array}$

Subfamily ?Anatinae Leach, $1820 \quad 17$

Tribe incertae sedis $\quad 17$

$\begin{array}{ll}\text { Genus Dunstanetta gen. nov. } & 17\end{array}$

Dunstanetta johnstoneorum gen. et sp. nov. $\quad 18$

Subfamily Anatinae Leach, $1820 \quad 19$

Tribe ?Anatini Leach, $1820 \quad 19$

Genus Matanas gen. nov. $\quad 19$

Matanas enrighti gen. et sp. nov. $\quad 20$

Order Accipitriformes Vieillot, $1816 \quad 20$

Family Accipitridae Vigors, 1824

Genus and species indet. $\quad 20$

Order Gruiformes Bonaparte, 1854

Family ?Aptornithidae Bonaparte, $1856 \quad 21$

$\begin{array}{ll}\text { Genus and species indet. } & 21\end{array}$

Family Rallidae Rafinesque, 1815

Genus indet. $\quad 21$

New species 1 - magn. Gallirallus striatus or G. philippensis assimilis 21

New species 2 - magn. Gallirallus philippensis goodsoni 22

Order Charadriiformes Huxley, $1867 \quad 23$

Family ?Laridae Rafinesque, 1815

Genus and species indet. $\quad 23$

Family, genus and species undetermined $\quad 23$

Order Columbiformes Latham, $1790 \quad 24$

Family Columbidae Illiger, 1811

Genus and species indet. $\quad 24$

Order Psittaciformes Wagler, $1827 \quad 24$

Family Psittacidae Rafinesque, $1815 \quad 24$

Genus and species indet. $\quad 24$

Order Aegotheliformes Simonetta, $1967 \quad 25$

Family Aegothelidae Bonaparte, $1853 \quad 25$

Genus Aegotheles Vigors \& Horsfield, $1827 \quad 25$

Aegotheles sp. indet. $\quad 25$

Family Apodidae Olphe-Gaillard, $1887 \quad 26$

Genus Collocalia Gray, $1840 \quad 26$

Collocalia sp. indet. $\quad 26$

Order Passeriformes Linnaeus, $1758 \quad 27$

Family Cracticidae Amadon, $1943 \quad 27$

$\begin{array}{ll}\text { Genus and species indet. } & 27\end{array}$

Passerine family, genus, species indet. $\quad 28$

Bird, family, genus, species indet. $\quad 28$

Avian eggshell - family, genus, species indet. $\quad 28$ 
Avian eggshell - Dinornithiformes, family, genus, species indet.

Discussion

The significance of the New Zealand Miocene avifauna

Worldwide significance of the New Zealand Miocene fauna

Conclusion

Acknowledgements

\section{INTRODUCTION}

The main islands of New Zealand lie between 34 and $47^{\circ} \mathrm{S}$, some $1400 \mathrm{~km}$ east of Australia, in the South Pacific Ocean. Most of the original continental fragment is now submerged beneath the ocean and New Zealand now comprises an archipelago of over 660 islands greater than 1 ha in area, with North Island $\left(114740 \mathrm{~km}^{2}\right)$, South Island $\left(151120 \mathrm{~km}^{2}\right)$ and Stewart Island $\left(966 \mathrm{~km}^{2}\right)$ accounting for $98.8 \%$ of the land. New Zealand was once part of Gondwana, but has been an archipelago since its separation from Australia and Antarctica around 82 million years ago (Ma; Cooper \& Millener 1993; Sutherland 1999).

The Recent indigenous terrestrial flora and fauna is highly distinctive and attests to a Gondwanan influence with Nothofagus (beech) and Podocarpus forests; arthropods such as velvet worms (Onychophora) and giant weta (Stenopelmatidae, Orthoptera); and vertebrates such as primitive frogs (Anura, Leiopelmatidae), tuatara (Rhynchocephalia, Sphenodontidae) and moa (Aves, Dinornithiformes). Some 245 breeding species of bird and approximately 64 lizards (Scincidae, c. 35 sp.; Gekkonidae, c. 29 sp.) dominate the Recent fauna, with land mammals represented by only three species of bats (Worthy \& Holdaway 2002).

New Zealand has a relatively rich Cenozoic record of marine birds, especially penguins, but there are few other described species (Fordyce \& Jones 1990; Turbott 1990; Fordyce 1991). In contrast, the terrestrial fossil vertebrate record, while very rich in the late Quaternary (Worthy \& Holdaway 2002), is one of the world's poorest for the preQuaternary period. Except for fragmentary Late Cretaceous (80-71 Ma) dinosaur material (Molnar \& Wiffen 1994) and isolated moa bones from marine sediments up to $2.5 \mathrm{Ma}$ (Worthy et al. 1991; Worthy \& Holdaway 2002), the terrestrial record older than $1 \mathrm{Ma}$ is very limited. A small avifauna from 1 Ma shoreline deposits near Marton, in the lower North Island, includes several species that are unknown from late Quaternary faunas and at least two Recent moa species (Worthy 1997).

The entire Cenozoic is represented by a single undescribed fauna from the Early-Middle Miocene Manuherikia Group, in Central Otago, South Island, known to contain two anatids and undetermined fish, discovered in 1978 (Douglas et al. 1981; Douglas 1986; Fordyce 1991). This fauna was extended by the discovery of a single crocodilian angular from the same formation in 1989 (Molnar \& Pole 1997).

The Manuherikia Group sediments have been the focus of much palaeobotanical work investigating both mac- rofloras and palynofloras (Mildenhall 1989; Mildenhall \& Pocknall 1989; Pole 1989, 1992a-c, 1993a-g, 1997; Pole \& Douglas 1998), culminating in the summary of vegetation and environment by Pole et al. (2003). Between the collection made by Ewan Fordyce et al. in 1980-1981, from the Vinegar Hill site (Fordyce 1991: 1234), and 2001, the only vertebrate specimen reported was a crocodilian angular, which was fortuitously exposed in a low cliff at an undisclosed locality (Molnar \& Pole 1997). Fordyce (1991: 1235) figured a carpometacarpus, a tarsometatarsus and a coracoid, identified as anatids, from his Vinegar Hill collections. Pole et al. (2003) have figured another anatid carpometacarpus and avian eggshell from the basal Bannockburn Formation in Mata Creek, which is also the source of the crocodilian angular (B. Douglas pers. obs.). Fordyce (2003) figured some of the bones from Vinegar Hill, which were presumed to represent a duck and a small goose.

In view of the obvious potential for vertebrates, we began our main investigation of the Manuherikia Group sediments specifically to find vertebrate faunas in NovemberDecember 2001 (Worthy et al. 2002a,b) after initial forays to the region in January 2000 (A.J.D.T.) and April 2001 (C.J.). We targeted strata where vertebrates might be concentrated and began by visiting the sites described by Douglas (1986) as having bird bones, as well as other Lower Bannockburn Formation exposures where similar bone deposits might be expected and whose palynology was described in Pole \& Douglas (1998). J.A.M., with guidance from Mike Pole (Pole et al. 2003: 420), began the investigation of the Mata Creek exposures. C.J., A.J.D.T. and T.H.W. worked at the sections on the Manuherikia River and Mata Creek. Our investigations of the Vinegar Hill exposures in 2001 suggested that they would be comparatively unfruitful and difficult to work, as they lacked running water for sieving operations, so we have since concentrated efforts on sites in the Mata Creek and Manuherikia River where the lower Bannockburn Formation is exposed.

Employing wet sieving techniques in the field and later sorting of the concentrate under laboratory conditions, we have recovered a rich and diverse vertebrate fauna, which we hereafter call the St Bathans Fauna. Mollusc remains are preserved in the beds, reflecting the alkaline nature of the sediments with fragments of the bivalves Hyridella sp. being most common, but rare freshwater and land gastropods are also present (site HH1a). Fish bones dominate all assemblages and represent two main taxa (numerous ?Gobiidae and rare Galaxiidae) and are not discussed further here. There are hundreds of fossils from other vertebrates that are identifiable at some taxon-level. The purpose of this paper is 
to place on record the diversity of the avifauna from the lower Bannockburn Formation in the Manuherikia Group. The remains of other terrestrial vertebrates, including sphenodontids, skinks and geckos, crocodilians and bats and other mammals alluded to in Worthy et al. $(2002 a, b)$ will be described elsewhere.

\section{Geological and palaeoenvironmental setting}

Terrestrial vertebrate bones are locally concentrated in late Early-Middle Miocene (Altonian Stage, 16-19 Ma) Manuherikia Group strata, identified at several outcrop sites near St Bathans, Central Otago, New Zealand (Fig. 1: Douglas et al. 1981; Douglas 1986; Molnar \& Pole 1997; Worthy et al. 2002a, b; Pole et al. 2003). A detailed stratigraphy and palaeogeographical reconstruction of the Manuherikia Group fluvial Dunstan Formation and overlying lacustrine Bannockburn Formation has been described by Douglas (1986). The ages of these strata are known from palynological evidence (Mildenhall \& Pocknall 1989) and from more recent detailed palynostratigraphical zonation of the terrestrial bone bearing outcrops (Pole \& Douglas 1998). The terrestrial bone-bearing beds in the Manuherikia River section are assigned to the Casuarinaceae biozone (Pole \& Douglas 1998: fig. 6) and correlated with late Early Miocene-earliest Middle Miocene. This period approximately corresponds with a profound environment change identified in the Manuherikia Group strata from warm ever-wet rainforest to cooler temperatures and pronounced seasons, also seen elsewhere in the world at about this time (Flower \& Kennett 1994).

The terrestrial bones typically occur in the lowest $30 \mathrm{~m}$ of the Bannockburn Formation (Fig. 2), mostly within discontinuous sandy or muddy sand layers of lacustrine shallow sublittoral-littoral (near shore) sediments. They are deposits of a large freshwater lake (Lake Manuherikia) that extended in excess of $5600 \mathrm{~km}^{2}$ (Douglas 1986). The lake was surrounded by a broad (extensive) fluvial plain with major channels and interchannel flood-basins. Shallow wetland habitats were vegetated by grasslands, herbfields and peat-forming swamp-woodland. Relatively dry Casuarinaceae woodland occurred nearby (Douglas 1986; Pole et al. 2003) and it can be inferred that deltas formed at major points of sediment entry to the lake.

\section{MethODS}

We collected bones during fieldwork in the following periods: 21-26 April 2001 (C.J.); 27 November-7 December 2001 (J.A.M.); 8-13 December 2001 A.J.D.T./T.H.W./C.J. et al.; 1-6 October 2002 (A.J.D.T./T.H.W. et al.); 1619 March 2003 (A.J.D.T./T.H.W. et al.); 18-25 February, 2004 (A.J.D.T./T.H.W. et al.).

Excavations were carried out at three main locations near St Bathans in Central Otago, South Island: 1, Manuherikia River $44^{\circ} 54^{\prime} 29^{\prime \prime} \mathrm{S}$; $169^{\circ} 51^{\prime} 30^{\prime \prime} \mathrm{E}$ in sites (= layers) we have termed $\mathrm{HH} 1 \mathrm{a}-\mathrm{e}, \mathrm{HH} 2$ and $\mathrm{HH} 3$ after Home Hills Station where the site is situated (see Fig. 1); 2, Mata Creek, particularly the 'Croc Site', $44^{\circ} 53^{\prime} 22^{\prime \prime} \mathrm{S}$; $169^{\circ} 50^{\prime} 16^{\prime \prime} \mathrm{E}$; 3, Vinegar Hill, 44 $52^{\prime} 37^{\prime \prime} \mathrm{S}$; $169^{\circ} 44^{\prime} 57^{\prime \prime} \mathrm{E}$.

The vertebrate fossils were mainly recovered from sandstone beds. The sediment was excavated by hand and gently washed over $1 \mathrm{~mm}$ to a maximum of $4 \mathrm{~mm}$ mesh sieves with as little mechanical disruption as possible. All material from HH1a during and after October 2003 was washed only on $1 \mathrm{~mm}$ mesh. Larger bones were collected in the field and all material that was retained on the sieves was bagged in bulk and later sorted under laboratory conditions a few grains at a time on trays. All vertebrate bone fragments, with the exception of shapeless slivers of fish bone, fish otoliths and land and freshwater gastropod fragments were recovered. T.H.W. and A.J.D.T. identified and catalogued the material into the fossil vertebrate collection, Museum of New Zealand Te Papa Tongarewa (MNZ). Mollusc remains were deposited in the mollusc collection, MNZ.

\section{Abbreviations}

\section{Institutions}

AM, Australian Museum, Sydney, Australia; ANWC, Australian National Wildlife Collection, CSIRO, Canberra, Australia; AU, Geology Department, University of Auckland, Auckland, New Zealand; BMNH, The Natural History Museum, London, United Kingdom; CM, Canterbury Museum, Christchurch, New Zealand; MNZ, Museum of New Zealand Te Papa Tongarewa, Wellington (formerly National Museum of New Zealand, Dominion Museum and Colonial Museum), New Zealand; UCBL, Université Claude Bernard-Lyon 1, St. Gérand-le-Puy, France.

\section{Skeletal elements and descriptive terms used}

The following abbreviations apply to single and plural usage of the elements. Ant, anterior; cmc, carpometacarpi; cor, coracoids; cran,cranium; fem, femora; fur, furculae; hum, humeri; pel, pelves; pt, part; rad, radii; scap, scapulae; stern, sternum; tib, tibiotarsi; tmt, tarsometatarsi.

Anatomical nomenclature for specific bone landmarks follows Baumel \& Witmer (1993) with English translations, or names following Howard (1929), thereafter. Some common terms are abbreviated as follows: artic., articularis; cond., condylus; m., musculi; proc., processus; tub., tuberculum. $\mathrm{L}$ is left and $\mathrm{R}$ is right elements. $\mathrm{L}$ or $\mathrm{R}$ elements are sometimes prefixed with either ' $p$ ' or ' $d$ ', to indicate that either the proximal or distal parts, respectively, of the element is represented.

\section{Measurements}

Measurements were made with Tesa ${ }^{\circledR}$ dial callipers and rounded to $0.1 \mathrm{~mm}$.

TL, greatest length, except for the coracoid (which was measured down the medial side) and femora (which were measured from the proximal end of the crista trochanteris to the cond. lateralis).

$\mathrm{PW}$, proximal width in the lateromedial plane; femora were measured from the caput femoris through the mid-depth point of the neck to the lateral side.

SW, shaft width at mid-length (except for tibiotarsi where it was the minimum value) in a lateromedial plane.

DW, distal width.

Tibiotarsi AL, length measured from the proximal articular surfaces to the cond. lateralis. 

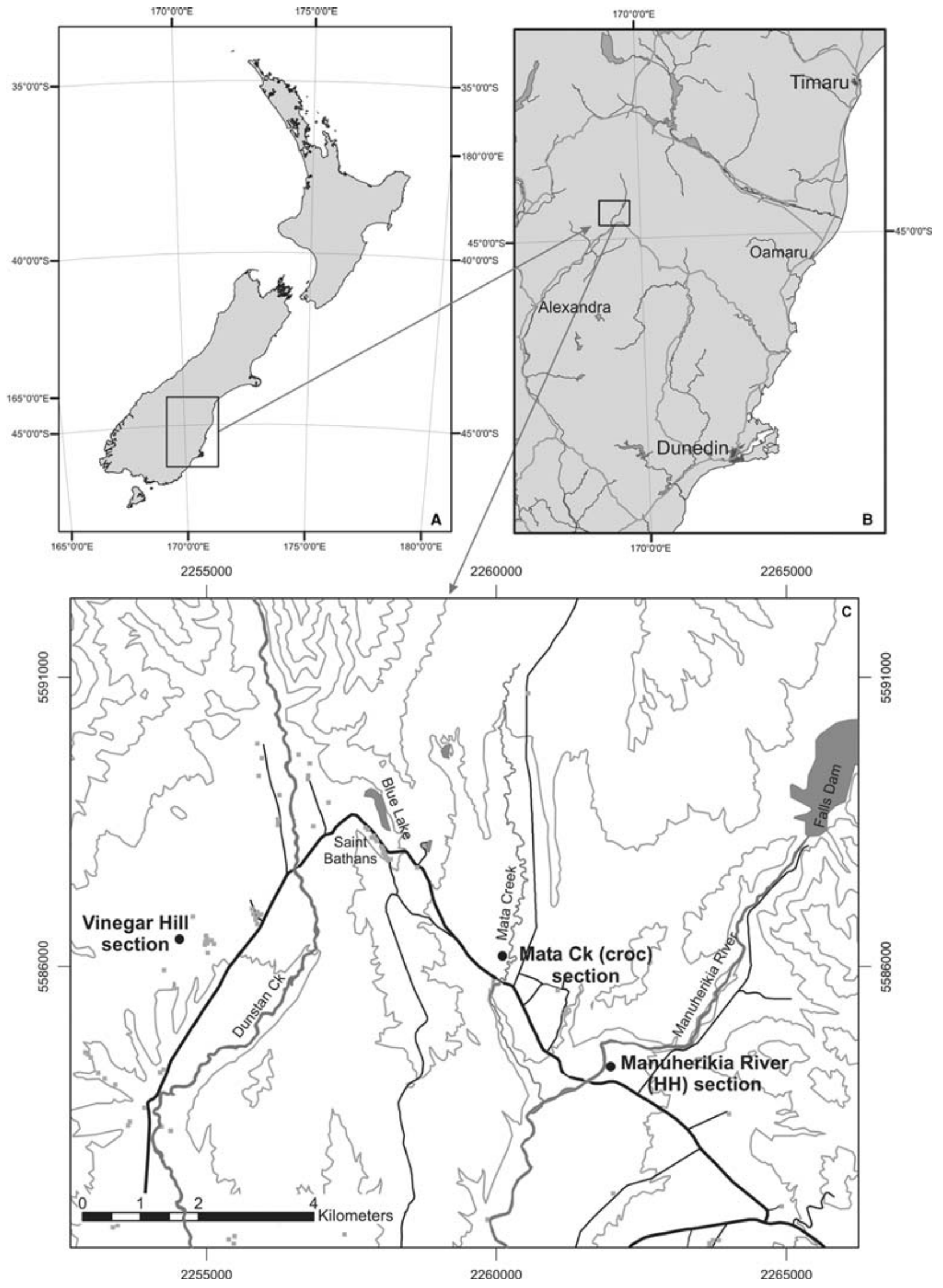

Figure 1 Location of the fossil sites within New Zealand. In C, roads (bold lines) and contours (light irregular lines) are shown as well as the Manuherikia River and its tributaries. Ck, Creek. 


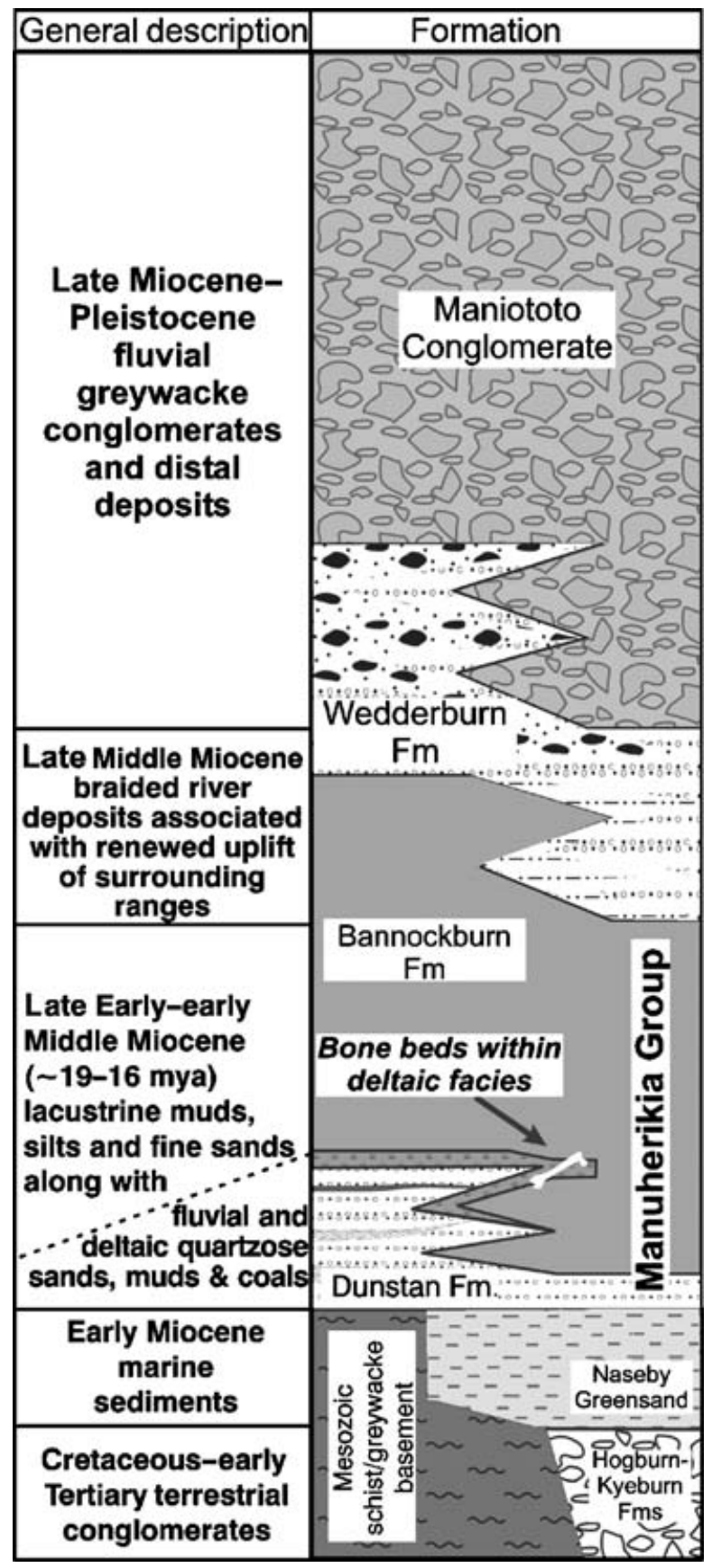

Figure 2 A generalised lithostratigraphy showing the relationship of the Manuherikia Group strata to bounding units, as well as the position of the fossil beds in the strata. Fm(s) formation(s).

Tibiotarsi PW, measured across the articular surface.

Tarsometatarsus DW, this was measured at right angles to the shaft.

\section{Comparative material}

The following comparative material was consulted during studies of the anatid material. All are modern unless stated otherwise. Reference specimens of non-anatid taxa specific- ally referred to are embedded in the text concerning the relevant families.

Anseranas semipalmata Latham, magpie goose: AM O59362; Dendrocygna arcuata (Horsfield), wandering whistling duck: AM O64697 male; Dendrocygna eytoni (Eyton), plumed whistling duck: MNZ 27024; Cereopsis novaehollandiae Latham, Cape Barren goose: MNZ 25217, 25143; Cnemiornis gracilis Forbes, North Island goose: fossil, notably MNZ S35683-706; Cnemiornis calcitrans Owen, South Island goose: fossil, notably MNZ S35266; Cygnus atratus (Latham), black swan: MNZ 15266, 15267, 17250; Cygnus olor (Gmelin), mute swan: MNZ 16454; Anser anser (Linnaeus), greylag goose: MNZ 20812, 24519; Branta canadensis (Linnaeus), Canada goose: MNZ 23745, 26738, 26739, 26740, 26741; Stictonetta naevosa (Gould), freckled duck: MNZ 25141; Thalassornis leuconotus Eyton, white-backed duck: BMNH 1901.10.20.156; Mionetta blanchardi (Milne-Edwards), fossil, Université Claude Bernard Lyon 1 (UCBL) from St. Gérand-le-Puy, France, all prefixed with FSL: L hum 332.274, R hum 332.277, R ulna 331.783, R ulna 331.788, L cmc 331.497, R cmc 331.492, $\mathrm{L}$ cor $331.364, \mathrm{R}$ cor $331.381, \mathrm{~L}$ fem $331.176, \mathrm{R}$ fem 331.185, L tib 331.104, R tib 331.109, L tmt 331.005, R tmt 331.007, CM Av11394, 2 ant stern, pt cran, fur, LR scap, pt 2 pel, LR MII.1, 2L1R cmc, R rad, LdR ulna, 1L2R cor, 1L2R hum, LR tmt, 1L3R tib, 1L2R fem, CM Av13902, 2L6R cor, 1R3L hum, 2L1R cmc, pt fur (both lots from St. Gérand-le-Puy); Oxyura australis Gould, blue-billed duck: CM Av31408; AM O65518; Oxyura jamaicensis (Gmelin), ruddy duck: ANWC 22640 (ANSS 386), ANWC 22641 (ANSS 391), MNZ 27335; Oxyura vantetsi Worthy, New Zealand blue-billed duck: specimens (fossil) listed in Worthy (2004a, 2005); Biziura lobata (Shaw), musk duck: MNZ 26190, 26191, CM Av7116; Malacorhynchus membranaceus (Latham), Australian pink-eared duck: MNZ 23880, 23881; Malacorhynchus scarletti Olson, Scarlett's duck: fossil humeri - MNZ S1276, 1823, 2379, 5145, 5492, 7584, 5714, 5736, 7599, 10080, 10477, 10478, 10966, 11447, 12190, 13119, 14153, 17097, 17226, 17655, 19400, 19505, 19506, 19531, 20758, 21656, 22402; fossil coracoids - MNZ S1939, 16632, 21082, 21541; Tadorna variegata (Gmelin), paradise shelduck: MNZ 15146, 16471, 16472, 16473, 16501, 16590, 24559, 25139, 25669, 26562, 26563; Tadorna radjah (Lesson), radjah shelduck: MNZ 26206, 26207; Tadorna tadornoides (Jardine \& Selby), Australian shelduck: MNZ 22921, 23888a, 27367, ANWC 22240; Tadorna tadorna (Linnaeus) common shelduck: MNZ 12280; Alopochen aegyptiaca (Linnaeus), Egyptian goose: ANWC 22239 (ANSS 753), male, BMNH 1930.3.24.217, unsexed; Chloephaga picta (Gmelin), upland goose: BMNH 1860.11.4.15; Cairina moschata (Linnaeus), muscovy duck. MNZ 19842; Stictonetta naevosa Gould, freckled duck: MNZ 25141; Hymenolaimus malacorhynchos (Gmelin), blue duck: MNZ 16699, 23924, 24586, 24587; Somateria mollissima (Linnaeus), common eider: MNZ 12277, 12278, 12279; Bucephala albeola (Linnaeus), bufflehead: MNZ 12708, 12709; Lophydytes cucullatus (Linnaeus), hooded merganser: MNZ 12706; Mergus australis Hombron \& Jacquinot, Auckland Island merganser: MNZ S30046, S31777, collections of fossils from Chatham Island; Mergus serrator Linnaeus, redbreasted merganser: MNZ 12707; Chenonetta finschi (Van Beneden), Finsch's duck: fossil, MNZ specimens, notably S35885; Chenonetta jubata (Latham), maned duck: MNZ 
1487, 23188a, 25142, 25400, 25194a; Nettapus pulchellus (Gould), green pygmy-goose: MNZ 27025, 27026; Anas chlorotis G. R. Gray, brown teal: MNZ 14978, 15628, 15935 (= CM Av31828), 18898, 21544, 22086, 22802, 22806, 24535, 24536, 24537, 25105, 25106, 26630, 26631, 26940a, 26941a, 26942a, 26943a, 26944a, 26945a, 26946, 26947, 26949, 26950a, 26951a, 26952a; Anas aucklandica (Gray), Auckland Island teal: MNZ 24367, 24052; Anas nesiotis (Fleming), Campbell Island teal: MNZ 25727, 26742; Anas gracilis Buller, grey teal: MNZ 19351, 19348, 19301, 19322, 13688, 19323, 26815 (ex 24545), 18099, 19324, CM Av36764; Anas superciliosa Gmelin, grey duck: MNZ 13686, 15030, 16586, 18132, 16476, 17341, 17261, 16698, 16584, 24607; Anas rhynchotis variegata (Gould), Australasian shoveler: MNZ 17000, 18971, 16591, 24588, 24589, CM Av36112, CM Av19237, CM Av19117, CM Av19238; Aix galericulata (Linnaeus), Mandarin duck: MNZ 27368; Aythya novaeseelandiae (Gmelin), New Zealand scaup: CM Av22382, CM Av22413, MNZ 8726, 13685, 16588, 16589, 17001, 17002, 17003, 23144, 24245; Aythya australis (Eyton), Australian white-eyed duck: AM O65772; Aythya affinis (Eyton), lesser scaup: MNZ 24041.

Extinct taxa were identified using the characters previously described as follows: Biziura (Worthy 2002), Oxyura vantetsi (Worthy 2004a, 2005), Malacorhynchus scarletti (Worthy 1995; Worthy \& Gill 2002) and Chenonetta finschi (Worthy \& Olson 2002). Most of the characters used are described in detail in the anatid comparisons given by Worthy $(2004 a)$.

\section{TAXONOMIC ISSUES}

In this work, specimens are identified to lowest taxonomic level using character suites. New taxa are defined by unique combinations of characters and differential diagnoses. In some cases preserved characters do not enable generic determination and, as the material is $16-19 \mathrm{Ma}$, we assume attribution to modern genera is possible but unlikely. For example, a distal half of a rail femur is similar in all the modern genera Gallirallus, Rallus, Dryolimnas or Gallinula, so is unlikely to be correctly referred even if these genera were extant in the early Miocene. In many cases, specimens can only be identified at the family level at present.

We use the term ' $c f$ ' (Latin confer $=$ to compare) to denote similarity and the term 'magn' (Latin magnitudino) to indicate similar size without implying a possible relationship, following Olson \& Rasmussen (2001). So, for example, ' $c f$ Pelecanoides sp., magn P. urinatrix' should be interpreted to mean that the specimen is similar to Pelecanoides and similar in size to $P$. urinatrix.

\section{TAPHONOMY}

Bed HH1a, in the Manuherikia River Section, from which many of the bones described here were recovered, is 6.88$7.00 \mathrm{~m}$ above the base of the Bannockburn Formation. It dips at $40^{\circ}$ to the southwest with a strike of $80^{\circ}$ North. HH1a comprises a greenish grey silt or fine sand locally intermixed with quartz granules/pebbles and organic debris, incorporating algae encrusted rip-up clasts of mud, rare oncolite fragments and abundant bone fragments. This material was probably reworked and concentrated by wave or current action in the littoral lake environment.

The clay layer underlying HH1a is slightly humped and hollowed $( \pm 5 \mathrm{~cm})$ over its lateral extent. The fossiliferous sands deposited on this surface contain ripples, about $10-12 \mathrm{~cm}$ between crests that indicate a current direction essentially down dip or parallel to the adjacent Manuherikia River. A result of this is that coarser material was deposited as lenses down-current of the humps on the lower clay layer.

In HH1a the fossil bones include many which are black in colour and usually have rounded edges. Others are brown in colour and generally have less wear. A few specimens of both brown and black fossils have algae-derived calcareous coatings. None of the vertebrate material is articulated and most bones are broken. Rounding may indicate wear due to fluvial transport, but the influence of biotic taphonomic agents such as crocodilians cannot be excluded and is known to be significant in, for example, Miocene lacustrine sites in Australia (J.A.M., unpubl. data). The fragmented nature of much of the material could be explained by its origin as predated remains left by either crocodilians or raptors. The predominance of distal wing elements and the relative scarcity of trunk elements such as pelves, sterna and vertebrae, could be explained by predation, but equally, these scarcely represented elements have a higher surface area-weight ratio enabling their selective removal by current from the depositional area. These observations indicate that in both sites, few specimens are in primary deposition sites, with most transported to some degree and some having been reworked from an earlier deposition event. There is, however, no significant time interval between these initial deposits as both preservation types contain the same species mix.

Layers HH1b-e in the Manuherikia River Section have similar sedimentary features to that of HH1a and so are presumed to have been deposited within similar near-shore conditions. HH2 in the Manuherikia River Section is stratigraphically about $14.3 \mathrm{~m}$ above HH1a. HH3 was a $2-3 \mathrm{~cm}$ thick lens of calcified reed and oncolite fragments, sandwiched between massive green clay layers about $300 \mathrm{~mm}$ thick and $1140 \mathrm{~mm}$ below the base of the sand layer $\mathrm{HH} 2 \mathrm{c}$. The HH2 sequence begins with a $160 \mathrm{~mm}$ thick green clay layer (HH2a), with abundant calcified reed and oncolite fragments in the lower $30 \mathrm{~mm}$. The primary bone-bearing horizon ( $\mathrm{HH} 2 \mathrm{~b}$ ) is a $30 \mathrm{~mm}$ thick clay/silt zone rich in calcareous fragments that underlies $\mathrm{HH} 2 \mathrm{c}$, a $170 \mathrm{~mm}$ thick layer of homogenous fine sands with rare bones throughout.

The 'Croc Site' beside Mata Creek was the other significant site we worked. It is so named as the main fossilbearing layer, which we term Layer 1, is the source of the crocodilian angular described by Molnar \& Pole (1997). This layer has similar depositional features to HH1a: a $5-10 \mathrm{~cm}$ thick bed of silty medium-coarse pale sand, with silt rip-up clasts laid down on a similar thickness of clean pale sands. Layer 1 is about $10 \mathrm{~cm}$ below a $>1 \mathrm{~m}$ thick shale bed (that presently caps the exposure) and c. $3.5 \mathrm{~m}$ above the Dunstan/ Bannockburn contact. The sand below Layer 1 rests on an irregular erosion surface and in places infills desiccation cracks; it varies in thickness along the exposure. The boundary between Layer 1 and the lower sand is marked by rust-coloured iron/gypsum concretions in the better drained parts of the exposure, which incorporate fossils in their upper half. 


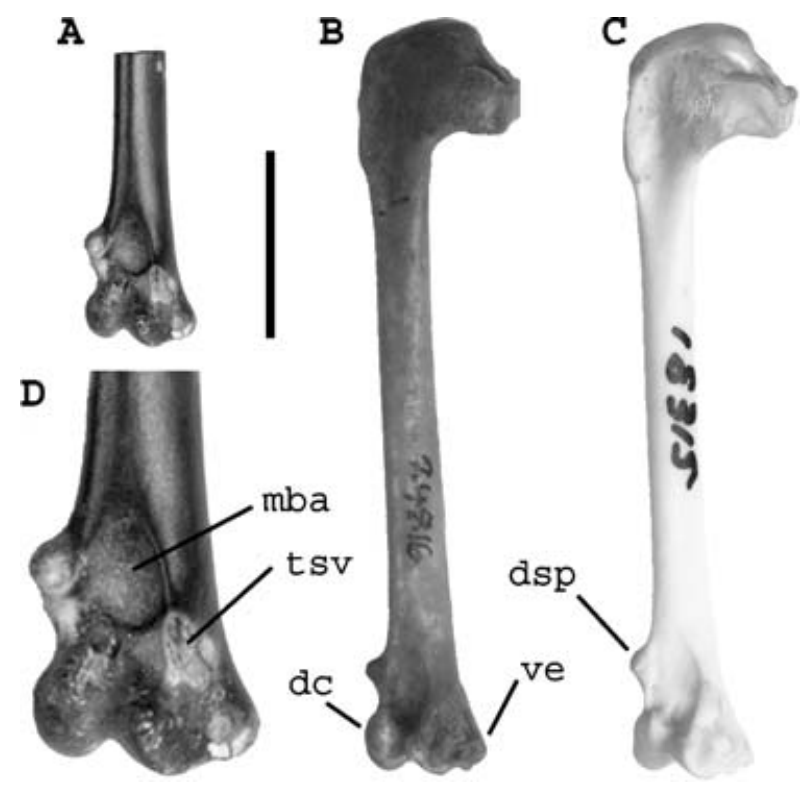

Figure 3 Comparison of Pelecanoides right humeri in cranial view. A, $P$. miokuaka sp. nov., MNZ S42431; B, P. georgicus, extant, MNZ 24816; C, P. urinatrix chathamensis, extant, MNZ 18315; D, $P$. miokuaka sp. nov., MNZ S42431 at 2x scale. Abbreviations: dc, dorsal condyle; dsp, dorsal supracondylar process; mba, musculus brachialis anticus; tsv, tuberculum supracondylare ventrale; ve, ventral epicondyle. Scale bar $=10 \mathrm{~mm}$.

\section{SYSTEMATIC PALAEONTOLOGY Order PROCELLARIIFORMES Fürbringer, 1888 Family PELECANOIDIDAE Gray, 1871 Genus PELECANOIDES Lacépède, 1799}

This bone (humerus) is identified as a diving petrel Pelecanoides sp. distinct from other procellariids because of the combination of the following features: the shaft is distinctly flattened, in cranial view the proximal origin of the cond. dorsalis is close to the dorsal margin rather than mid way between the dorsal margin and the tub. supracondylare ventrale as is the case in Puffinus, the proc. supracondylaris dorsalis is short, blunt and not rotated cranially, the fossa $\mathrm{m}$. brachialis is relatively shallow and the epicondylaris ventralis is relatively elongate.

\section{Pelecanoides miokuaka sp. nov. (Figs 3A, D)}

HoLOTYPE. MNZ S42431, distal right humerus.

LOCALITY AND HORIZON. Croc Site L1, in 3 m cliff north side of small hill left side Mata Creek, Otago, New Zealand, (44 $53^{\prime} 22^{\prime \prime} \mathrm{S}$; $\left.169^{\circ} 50^{\prime} 16^{\prime \prime} \mathrm{E}\right)$. Layer $1, c .10 \mathrm{~cm}$ thick siltysand layer, c. $3.5 \mathrm{~m}$ above the Dunstan/Bannockburn contact, Manuherikia Group, Early-Middle Miocene, 19-16 Ma.

MEASUREMENTS. Maximum distal width through condyles $=6.4 \mathrm{~mm}$, shaft width at proximal side of the dorsal supracondylar process $=3.6 \mathrm{~mm}$.
ETYMOLOGY. From the Miocene age and the Maori name for diving petrels 'kuaka'.

Diagnosis. A Pelecanoides species of similar size to $P$. georgicus Murphy \& Harper, 1916 that differs from all known species by the following combination of features: the impression of musculus brachialis anticus within the brachial fossa being deeper and deepest distoventrally and extending dorsally to the base of the dorsal supracondylar process, the cond. ventralis is not linked to the ventral supracondylar tubercle by a ridge, resulting in the facies between the ventral supracondylar tubercle and the ventral condyle being flat rather than housing a broad fossa and the ventral epicondyle has smaller ligamental attachment points and is smaller.

REMARKS. The fossil is similar in size to humeri of $P$. georgicus and slightly smaller than those of $P$. urinatrix Gmelin, 1789 (Table 1). In modern taxa (specimens listed, Table 1), e.g. P. u. chathamensis Murphy \& Harper, 1916 (Fig. 3C), P. u. exsul Salvin, 1896, P. u. urinatrix Gmelin, 1789, P. georgicus (Fig. 3B) and P. garnotii (Lesson, 1828), the humerus has a shallow impression of musculus brachialis anticus (see Howard 1929: fig 21) which is not noticeably deeper distoventrally and which, only in some $P$. georgicus, extends to the base of the dorsal supracondylar process. As in all of these taxa, the fossil has a pneumatic foramen in the brachial fossa adjacent to the dorsal condyle. In modern taxa there is a prominent ridge linking the ventral condyle and the ventral supracondylar tubercle, which results in the facies between the supracondylar tubercle and the ventral condyle housing a broad fossa. In these taxa, the ligamental attachment points on the cranio-ventral facies of the ventral epicondyle, otherwise called the entepicondylar prominence (Howard 1929), are larger than those in the fossil and more distally directed. Humeri of $P$. magellani (Mathews, 1912-1913) were not examined, but as this taxon is considered close to $P$. georgicus and as $P$. garnotii is the most divergent of modern forms (Penhallurick \& Wink 2004), yet still has identical distal humerus morphology to the others, it is unlikely that P. magellani differs from other modern taxa in this respect.

Pelecanoides miokuaka was not compared directly with P. cymatotrypetes Olson, $1985 a$ of Early Pliocene age from South Africa, which was diagnosed on features of the proximal humerus and coracoid. Pelecanoides cymatotrypetes did not differ in any other way from the modern taxa (S. Olson, pers. comm., 26 June 2004) and it is of similar size to $P$. $u$. exsul and so slightly bigger than MNZ S42431. Therefore $P$. miokuaka is not only geologically very much older than any other known specimen, but is qualitatively distinct from all known Pelecanoides species.

\section{Order ANSERIFORMES Wagler, 1831 Family ANATIDAE Leach, 1820}

There are a great number of anatid bones in the St Bathans Fauna, but as there is no association of bones of individuals, with one exception, and as some taxa overlap in size, only sufficient fossils to characterise the taxa represented are presented below. In Anseriformes, the most useful post-cranial element for determining phylogenetic relationships is the 
Table 1

Dimensions (mm) of humeri for Pelecanoides species compared to the fossil MNZ S.42431.

\begin{tabular}{|c|c|c|c|c|c|c|}
\hline Maximum DW & georgicus & exsul & chathamensis & urinatrix & garnotii & S.42431 \\
\hline Mean & 6.5 & 6.9 & 6.9 & 7.2 & 8.0 & 6.4 \\
\hline Standard error & 0.12 & 0.04 & 0.06 & 0.09 & & \\
\hline Standard deviation & 0.34 & 0.24 & 0.21 & 0.35 & & \\
\hline Minimum & 6.0 & 6.5 & 6.7 & 6.5 & & \\
\hline Maximum & 7.1 & 7.4 & $7 \cdot 3$ & 7.8 & & \\
\hline Count & 8 & 33 & 11 & 15 & 1 & \\
\hline SW above brachial fossa & georgicus & exsul & chathamensis & urinatrix & garnotii & S.42431 \\
\hline Mean & 3.6 & 3.7 & 3.8 & 4.0 & 4.4 & 3.6 \\
\hline Standard error & 0.06 & 0.03 & 0.06 & 0.05 & & \\
\hline Standard deviation & 0.17 & 0.20 & 0.20 & 0.19 & & \\
\hline Minimum & 3.4 & 3.2 & 3.5 & 3.7 & & \\
\hline Maximum & 3.9 & 4.1 & 4.1 & $4 \cdot 3$ & & \\
\hline Count & 8 & 33 & 11 & 15 & 1 & \\
\hline
\end{tabular}

Shaft width above the brachial fossa was taken immediately proximad of the dorsal supracondylar process. Specimens used: $P$. urinatrix chathamensis (MNZ 26821, 27178, 27223, 807, 18097, 18098, 18277, 18315, 18316, 18341, 27232); P. urinatrix urinatrix (MNZ 25644, 25645, 25646, 25647, 25648, 25649, 25724, 26370, 27150, S.35324); P. urinatrix exsul (MNZ 893, 908, 17623, 17624, 17625, 18096, 24785, 24786, 25848, 26371, 26372, 26564, 26565, 26883 (left), 27013, 27014); P. georgicus (MNZ 24790, 24816, 24817, 24818, 24819, 24820, 24821, 24822); P. garnotii (USNM 614776).

DW, distal width; SW, shaft width at mid-length.

humerus (Woolfenden 1961; Worthy 2004a). The coracoid is often found complete in fossil faunas and is also an important taxonomic element (Woolfenden 1961). Pelvic elements, while specifically very diagnostic, tend to have morphologies dominated by functional adaptations. For example, the diving anatids Aythya, Mergus and Oxyura have grossly similar leg bones but are not considered to be very closely related (Donne-Goussé et al. 2002; Sraml et al. 1996). As humeri and coracoids dominate the St Bathans Fauna, while crania, sterna and pelves are only represented by fragments, we define anatid taxa on humeri with some comment on referred coracoids. More complete skeletal descriptions and a detailed phylogenetic assessment of taxa awaits correct attribution of other skeletal elements to taxa following future analyses and fossil finds.

\section{Subfamily DENDROCHENINAE Livezey \& Martin, 1988}

The following taxon is referred to Dendrocheninae as the humerus has the unique combination of characters, in part listed by Livezey \& Martin (1988): (1) it is not elongate being proportioned as in Anas; (2) a prominent capital shaft ridge is directed towards an elevated tub. dorsale (dorsal tubercle); (3) presence of a broad flattened dorsal part of the fossa pneumotricipitalis with plane sub-parallel to shaft; (4) the crista deltopectoralis (deltoid crest) is dorsally concave; (5) the ventral part of the fossa pneumotricipitalis is closed or not pneumatic; (6) the space between the tub. supracondylare ventrale (facet for the anterior articular ligament) and the cond. dorsalis (dorsal condyle) is wider than the facet, unlike members of the more primitive Dendrocygninae where the space is narrower (Woolfenden 1961: 6); (7) absence of a distinct proc. supracondylaris dorsalis (dorsal supracondylar process). At least the characters (1), (2), (3), (5), (6) and (7) are derived with respect to Anseranatidae and Anhimidae, the sister taxon of Anatidae, and are derived with respect to Dendrocygna, e.g. D. eytoni (Eyton, 1838). Char- acters (1), (2) and (3) are derived with respect to Thalassornis within Anatidae.

Other than members of the Dendrocheninae, a closed ventral pneumotricipital fossa (character 5) is shared by Thalassornis, Oxyura, Biziura, Malacorhynchus and tribe Aythyini. However, humeri of Thalassornis are more elongate with the capital shaft ridge directed towards the head and they lack a distinct dorsal part to the pneumotricipital fossa. In Thalassornis, Oxyura and Biziura, the attachment point of the superficial pronator muscle has merged with the ventral edge of the attachment for the anterior articular ligament and Thalassornis and Biziura have a much more elongated deltoid crest. Aythyini lack a capital shaft ridge, do not have an elevated dorsal tubercle and have a convex dorsal surface to the deltoid crest.

\section{Genus MANUHERIKIA gen. nov.}

TYPE SPECIES. Manuherikia lacustrina gen. et sp. nov., by monotypy.

ETyMology. After the region in Central Otago and the name of the geological formation from which the fossils are derived. The gender is feminine.

DiAGNOSIS. Small dendrochenines characterised by the following combination of humeral characters: (1) the dorsal tubercle is ovate with the long axis aligned with the shaft; (2) the dorsal part of the ventral pneumotricipital fossa is deeply excavated under the head caudally between the capital shaft ridge and the incisura capitis (capital groove); (3) the crus dorsale fossae is large and prominent, extending distally to a point level with where the crista bicipitalis joins the shaft; (4) the fossa $\mathrm{m}$. brachialis is deep and bound by a sharp ridge medially; (5) the facet for the attachment for the anterior articular ligament is elevated and tilted distally; (6) the attachment point for the $m$. pronator superficialis (superficial pronator muscle) on the ventral facies is level with 
the tip of the facet for the attachment for the anterior articular ligament.

REMARKS. Livezey \& Martin (1988) reported that, in Mionetta blanchardi (Milne-Edwards, 1863), the muscle scar of the external head of the triceps (dorsal pneumotricipital fossa herein) does not undercut the head as it does in Dendrochen robusta Miller, 1944. In the specimens of blanchardi available to us, the dorsal pneumotricipital fossa does undercut the head, as it does in Manuherikia, so we assume that it does so to a greater extent in Dendrochen. Livezey \& Martin (1988) also reported that, in Mionetta, the attachment facet for the anterior articular ligament is not elevated and parallels the palmar surface of the shaft rather than being rotated distally. However, in the specimens available to us, we note that while the facet is relatively smaller than in Manuherikia, it is elevated and rotated distally when examined from the medial perspective. Mionetta differs further from Manuherikia by a relatively deeper brachial depression that is separated from the medial margin by a broader and rounded ridge.

Livezey \& Martin (1988) stated that Dendrocheninae was characterised by caudal (anconal) prominence of the epicondylus dorsalis (ectepicondyle) relative to the processus flexorius (entepicondyle) when the humerus is resting on its cranial surface. However, this is constrained by the development and size of the deltoid crest that prohibits rotation of the distal end when the bone rests on its cranial surface. Thus, for example, the unrelated Tadorna variegata (Gmelin, 1789) has the 'dendrochenine' condition depicted in Livezey \& Martin (1988: figs 4A, B). That Manuherikia humeri, when lying on their cranial surface, have both dorsal and ventral condyles touching the resting surface and therefore the entepicondyle and ectepicondyle on a plane parallel to that surface does not preclude their membership in Dendrocheninae.

Humeri of Manuherikia are most similar to those of either Mionetta blanchardi or Malacorhynchus. They differ from Mionetta in that the shape of the dorsal tubercle is ovate with its long axis parallel to the shaft rather than semi-triangular with its short axis along the shaft as in $\mathrm{Mi}$ onetta. A major difference is in the deep brachial depression bounded by a sharp ridge medially, whereas Mionetta has a well rounded ridge medially. Malacorhynchus differs from
Manuherikia in that the humerus has a more sigmoid shaft that does not narrow distally, the capital groove opens into the dorsal part of the pneumotricipital fossa at the same depth as the fossa even though the fossa is excavated under the head. The capital shaft ridge is less well developed only in the smaller M. membranaceus (Latham, 1802), it being well developed in M. scarletti Olson, 1977a. The crus dorsale fossae does not extend so far distally in Malacorhynchus as in Manuherikia and Mionetta.

Oxyura shares with Manuherikia an elongate and prominent crus dorsale fossae, but it differs markedly as the deep fossa extending under the head is greatly expanded dorsally so that its flat floor occupies the area where the capital shaft ridge lies in Manuherikia.

Manuherikia lacustrina gen. et sp. nov. (Figs $4 \mathrm{G}, \mathrm{H}$, 5D, H, I, 6D)

HoLOTYPE. MNZ S42307 complete L humerus with part of the distal margin of the bicipital crest missing (Figs $4 \mathrm{H}$, $5 \mathrm{H})$.

TYPE LOCALITY. Home Hills Station, Site 1a (HH1a), true left side Manuherikia River, Otago, New Zealand, $44^{\circ} 54^{\prime}$ $29^{\prime \prime} \mathrm{S} ; 169^{\circ} 51^{\prime} 30^{\prime \prime} \mathrm{E}$.

HORIZON. Bed HH1a, a sand layer $6.88-7.0 \mathrm{~m}$ above the base of the Bannockburn Formation, Manuherikia Gp, EarlyMiddle Miocene, 16-19 Ma.

DistRIBUTION. Layers HH1a, HH1b, HH2b, all on Manuherikia River section, Croc Site L1, Mata Creek, Otago, New Zealand.

\section{MeAsurements of HOlOTYPe. See Table 2.}

PARATYPES. MNZ S40094 pL humerus, HH1a; MNZ S42306 complete R humerus, HH1a (Figs 4G, 5D, 5I); MNZ S42308 worn R humerus, HH1a.

ETYMOLOGY. To reflect the fact that this bird lived in a lake.

DIAGNOSIS. A species of Manuherikia about the size of Anas rhynchotis Latham, 1802, in which the humerus shaft narrows distally and the dorsal part of the pneumotricipital fossa is

Table 2 Measurements (mm) of humeri (hum) and coracoids (cor) of Manuherikia lacustrina sp. nov.

\begin{tabular}{|c|c|c|c|c|c|c|c|c|c|}
\hline Site & Cat No. MNZ S & Element & $\mathrm{TL}$ & PW dt-bc & Depth ch & SW max & $\mathrm{SW} \min$ & DW & Depth dc \\
\hline HH1a Holotype & 42307 & L hum & 76.1 & 15.7 & 5.6 & 5.9 & 4.9 & - & 5.7 \\
\hline $\mathrm{HH} 1 \mathrm{a}$ & 42306 & R hum & 73.9 & $13 \cdot 3$ & 5.6 & 5.2 & $4 \cdot 5$ & 9.7 & 5.8 \\
\hline $\mathrm{HH}_{12}$ & 40094 & pL hum & - & 16.3 & 5.7 & 5.9 & - & - & - \\
\hline \multirow[t]{2}{*}{$\mathrm{HH} 1 \mathrm{a}$} & 42308 & R hum & 70.3 & - & 4.9 & $5 \cdot 5$ & 4.1 & - & $5 \cdot 4$ \\
\hline & & & $M L$ & L p-ma & $\mathrm{Lhf}$ & & SW & DW & \\
\hline$\overline{\mathrm{HH}} 1 \mathrm{a}$ & 40455 & L cor & 39.8 & 30.5 & 8.2 & & 4.2 & 16.2 & \\
\hline $\mathrm{HH}_{1} \mathrm{a}$ & 42310 & L cor & - & 32.1 & 9.6 & & 4.2 & - & \\
\hline $\mathrm{HH}_{1} \mathrm{a}$ & 42309 & L cor & 40.6 & 30.8 & 8.7 & & 4.2 & 17.0 & \\
\hline $\mathrm{HH} 1 \mathrm{a}$ & 42311 & L cor & 40.5 & 30.8 & 8.9 & & $4 \cdot 5$ & - & \\
\hline $\mathrm{HH} 1 \mathrm{a}$ & 40095 & pR cor & - & - & 8.5 & & 3.9 & - & \\
\hline $\mathrm{HH} 1 \mathrm{a}$ & 40454 & R cor & $45 \cdot 3$ & $35 \cdot 7$ & 9.7 & & 4.2 & - & \\
\hline
\end{tabular}

Humeri: TL, total length; PW dt-bc, proximal width from dorsal tubercle to bicipital crest; Depth ch, depth caput humeri; SWmax, maximum shaft width at mid-length; SWmin, minimum shaft width in caudal view; DW, greatest distal width; Depth dc, depth dorsal condyle.

Coracoids: ML, length down medial side; L p-ma, length from procoracoid to medial angle; $L$ hf, length of humeral facet; DW, width sternal articulation. Element: L, left; R, right; P, proximal. 
A

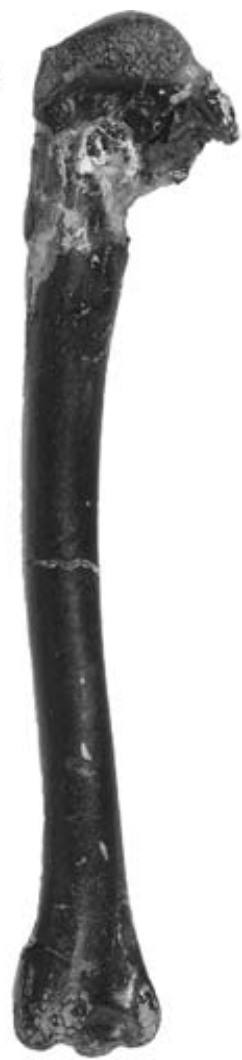

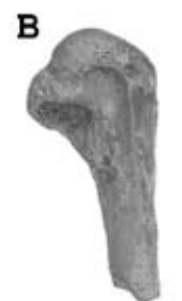

D

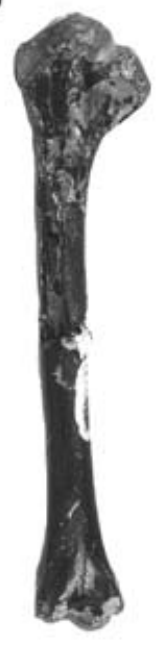

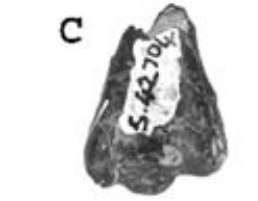

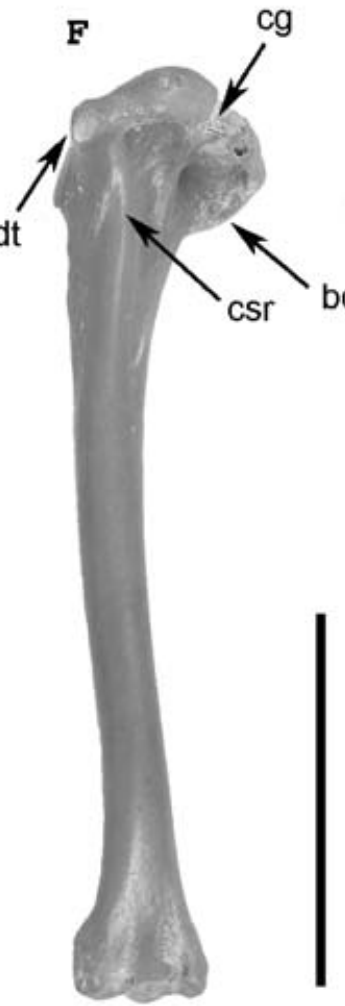

$\mathbf{E}$

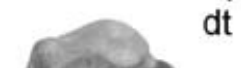

G

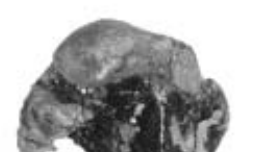

bc

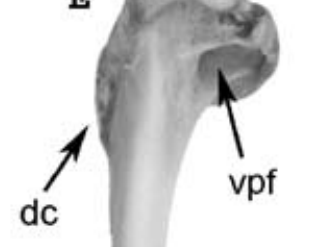

dc

Figure 4 Comparison of fossil and recent humeri in caudal view. A, Matanas enrighti gen. et sp. nov., holotype MNZ S42281; B, Manuherikia minuta gen. et sp. nov., paratype MNZ S41067; C, Matanas enrighti gen. et sp. nov., paratype MNZ S42704; D, Manuherikia minuta gen. et sp. nov., holotype MNZ S42317; E, Malacorhynchus membranaceous, Recent, MNZ 23881; F, Mionetta blanchardi, from St Gérand-le-Puy, FSL 332.274; G, Manuherikia lacustrina gen. et sp. nov., paratype MNZ S42306; H, Manuherikia lacustrina gen. et sp. nov., holotype MNZ S42307. Abbreviations: bc, bicipital crest; cg, capital groove; csr, capital shaft ridge; dc, deltoid crest; dt, dorsal tubercle; vpf, ventral pneumotricipital fossa (closed - not pneumatic). Scale bar $=30 \mathrm{~mm}$.

very deeply excavated, forming an abrupt drop from the capital groove into the fossa.

REFERRED MATERIAL. HH1a - MNZ S40438, dR hum; S40474, dR hum; S40476, dL hum; S42326, dL hum; S42624, pL hum; S42625, dL hum; S42626, dR hum; S42627, pL hum; S42628, dR hum; S42701, dL hum; S42702, dR hum; S42703, pL hum; S42739, dR hum; S42745, R hum; S42746, dL hum; S42747, dL hum; S42748, dR hum; S42749, pR hum; HH1b - S40961, dL hum; Croc Site L1 - S42222, dL hum; S42223, dR hum; S42237, pR hum; S42238, pR hum; S42239, dR hum; S42240, pR hum; S42243, dL hum; S42367, pR hum; S42368, dL hum; S42393, pLpR hum; S42394, pL hum; S42417, pL hum; S42418, pL hum; S42508, pL hum; S42509, pR hum; S42510, dL hum; S42529, dR hum.

MNZ S40454, R cor; S40455, L cor; S42311, L cor; S42309, L cor; S42310, L cor (Fig. 6D); S40095, pR cor; S40087, L cor; S41056, pR tib with most of shaft; S42722, L tib; S42241, R fem; S42242, L fem; S42798, L tmt; S42565, $\mathrm{L}$ tmt. There are many other 'medium-sized' anatid bones that probably belong to this taxon, but we refrain from referring them to species at this stage pending better knowledge of the sympatric similar-sized taxa described below.

MEASUREMENTS. See Table 2.
REMARKS. Humeri of Manuherikia lacustrina are most similar to those of either Mionetta blanchardi (Figs 4F \& 5J) or Malacorhynchus scarletti. They differ from both Mionetta and Malacorhynchus, in addition to the generic difference listed above, most notably in that the shaft narrows distally and the distal end is narrower, similar to the condition in Oxyura.

While no associated bones of single skeletons are known, the size and relative frequency of taxa among element types allows probable referral of other skeletal elements. Humeri of Manuherikia lacustrina are common and only the sympatric Matanas (described herein) has a similar length humerus, but it is known from few specimens. Associated femora, tibiotarsi and tarsometatarsi of appropriate size each have one abundant morphotype for which the femur has the shaft bent ventrally over its distal third of length and a deep fossa poplitea, the tibiotarsus has enlarged cnemial crests and a flattened anterior surface, while the tarsometatarsus is relatively short, with a broader than deep shaft and trochlea metatarsi II strongly deflected towards the plantar surface and set proximally relative to trochlea IV such that it does not extend distally as far as the inter-trochlear notch between trochea II and IV. These features are typical of diving ducks, which, along with the tapering shaft of the humerus (seen in Mergus, Aythya and Oxyura) suggests this taxon was a specialist diver. Although Livezey \& Martin (1988) 
A

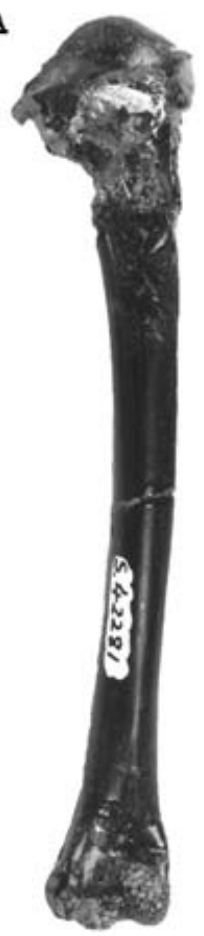

B

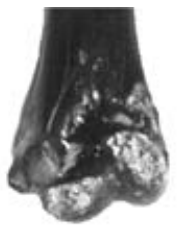

C

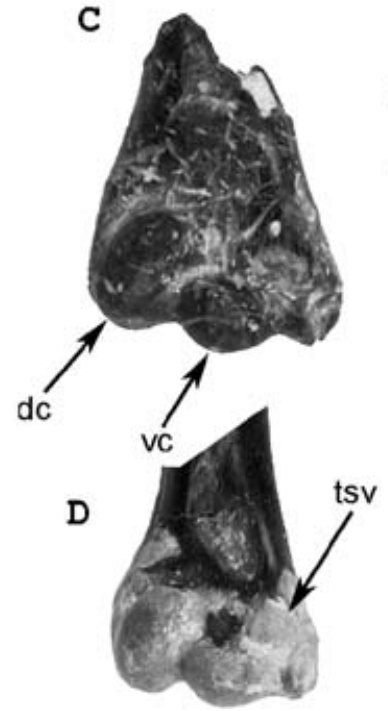

E

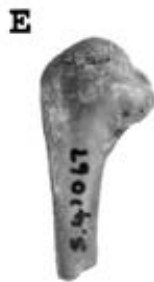

$\mathbf{F}$

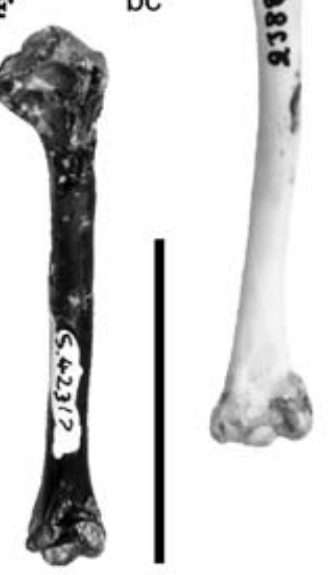

H

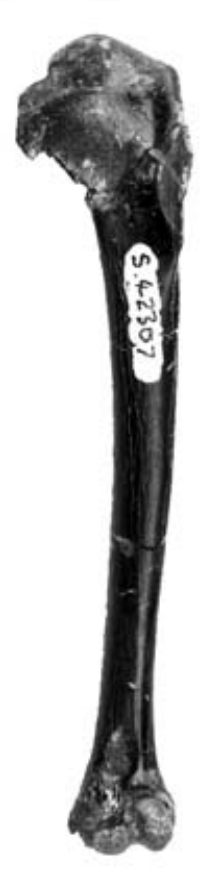

I

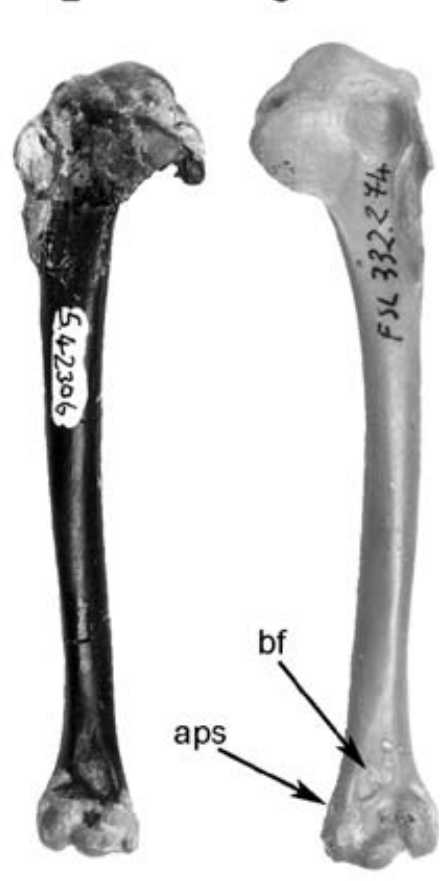

Figure 5 Comparison of fossil and Recent humeri in cranial view. A, Matanas enrighti gen. et sp. nov., holotype MNZ S42281; B, F, Manuherikia minuta gen. et sp. nov., holotype MNZ S42317; C, Matanas enrighti gen. et sp. nov., paratype MNZ S42704; D, I, Manuherikia lacustrina gen. et sp. nov., paratype MNZ S42306; E, Manuherikia minuta gen. et sp. nov., paratype MNZ S41067; G, Malacorhynchus membranaceous, Recent, MNZ 23881; H, Manuherikia lacustrina gen. et sp. nov., holotype MNZ S42307; J, Mionetta blanchardi, from St-Gérand-le-Puy, FSL 332.274. Abbreviations: aps, fossa for attachment of superficial pronator muscle; bc, bicipital crest; bf, brachial fossa; dc, dorsal condyle; h, head; tsv, tubercle for attachment of anterior articular ligament; vc, ventral condyle. Scale bar $=30 \mathrm{~mm}$, but B, C, D are at 2x scale.

suggested Mionetta was moderately specialised for diving on the basis of a closed ventral pneumotricipital fossa, a sternal pneumatic foramen and compression of the distal tarsometatarsus, we note that diving taxa such as Mergus have an open or highly pneumatic ventral pneumotricipital fossa and that Mionetta femora lack strong dorso-ventral shaft curvature and have a shallow popliteal fossa, the tibiotarsi lack anterior flattening of the shaft and elevated cnemial crests, while the tarsometatarsus lacks a dorsoplantarly flattened shaft and the trochlea for digit II is not strongly recurved distally, as in the manner of all specialised diving ducks.

Fossil anatid coracoids of appropriate size have two morphotypes, of which the common sort is taken to be Manuherikia lacustrina (Fig. 6D). In these, the proc. acrocoracoideus (acrocoracoid) lacks any pneumatic foramina and overhangs the shaft medially, the facies artic. clavicularis (facet for articulation of clavicle or brachial tuberosity) is notched between the dorsal and ventral lobes, the dorsal lobe of the clavicle facet overhangs the sulcus $m$. supracoracoidei, the supracoracoidal sulcus is not excavated under the facies artic. humeralis (humeral facet), the proc. procoracoideus (procoracoidal process) lacks a foramen, the ventral surface of the blade has a shallow hollow or impressio $m$. supracoracoideus, immediately anterior of the facies externa of the crista artic. sternalis, and the ventral sternal facet is not prominent (Fig. 6D).

Mionetta (Fig. 6E) and Malacorhynchus (Fig. 6B) coracoids share all these features, except in both the hollow on the ventral blade surface is deeper than in Manuherikia, as noted for Mionetta, but not Malacorhynchus, by Livezey \& Martin (1988). Furthermore, Malacorhynchus has a prominent ventral sternal facet and the acrocoracoid overhangs the shaft to a greater extent. Lack of pneumatic foramina in the acrocoracoid is a plesiomorphic feature shared with $A n$ seranas, Thalassornis and Dendrocygna (Livezey 1996a). Its presence in anserines and tadornines (although secondarily lost in many of the latter) appears to be an apomorphic state. At least two apomorphic characters distinguish Anseranas coracoids from those of all other anatids: the presence of a large pneumatic fossa dorsally and cranial of the sternal facet and a procoracoidal foramen that opens into the shaft. Dendrocygna and Thalassornis differ from Dendrochenines in that the impressio $\mathrm{m}$. supracoracoideus forms a very distinct and deep depression on the ventral blade surface (Livezey 1986, 1996a), a feature shared with Stictonetta.

Manuherikia lacustrina is the most abundant bird species in the Manuherikia Group deposits.

\section{Manuherikia minuta gen. et sp. nov. (Figs $4 \mathrm{~B}$, $D, 5 B, E, F, 6 A)$}

HoLOTYPE. MNZ S42317 complete L humerus with shaft crushed caudally (Fig. 4D, 5B, 5F).

LOCALITY AND HORIZON. Home Hills Station, Site 1a (HH1a), true left side Manuherikia River, Otago, New 


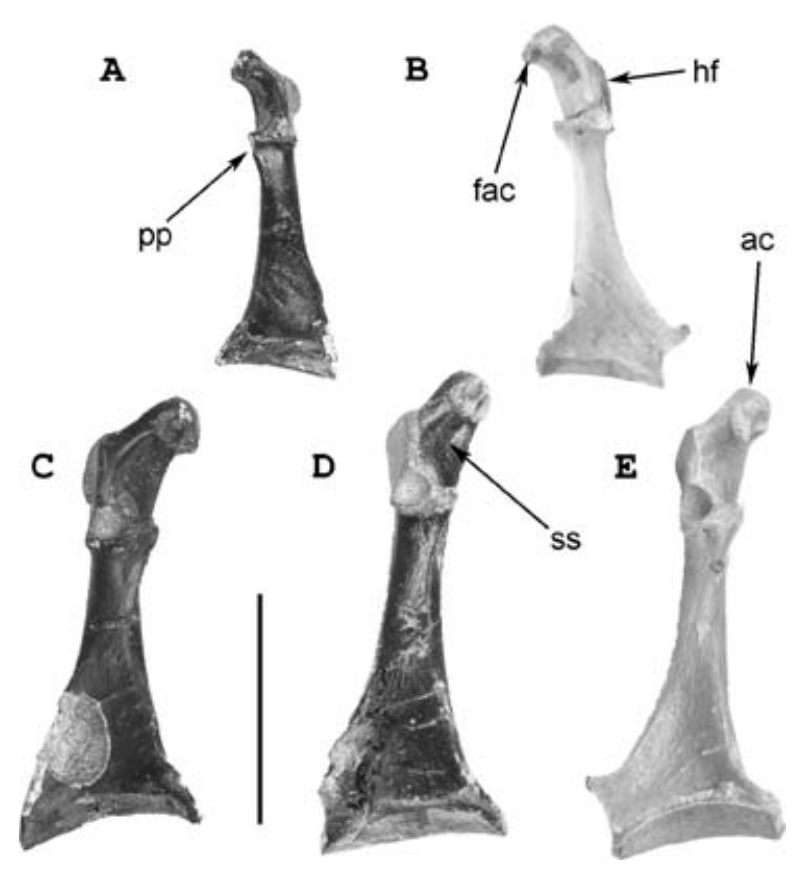

Figure 6 Comparison of fossil and Recent coracoids referred to as follows: A, Manuherikia minuta gen. et sp. nov. MNZ S42804; B, Malacorhynchus membranaceous, recent, MNZ 23881 (reversed); C, Matanas enrighti gen. et sp. nov., MNZ S42312; D, Manuherikia lacustrina gen. et sp. nov., MNZ S42309; E, Mionetta blanchardi, from St-Gérand-le-Puy, FSL 331.364. Abbreviations: ac, acrocoracoid; fac, facies articularis clavicularis; hf, humeral facet; pp, procoracoidal process; ss, supracoracoidal sulcus. Scale bar $=20 \mathrm{~mm}$.

Zealand, $44^{\circ} 54^{\prime} 29^{\prime \prime} \mathrm{S} ; 169^{\circ} 51^{\prime} 30^{\prime \prime} \mathrm{E}$. Bed HH1a, a sand layer 6.88-7.0 $\mathrm{m}$ above the base of the Bannockburn Formation, Manuherikia Gp, Early-Middle Miocene, 16-19 Ma.

DistriBUTION. Beds HH1a and HH2 on Manuherikia River section, Croc Site L1, Mata Creek, Otago, New Zealand.

MeAsurements of HOLOTYPE. See Table 3.

PARATYPES. MNZ S41067, pR hum, Croc Site L1 (Figs 4B, 5E); MNZ S42809, R hum, Croc Site L1; S40472, dL hum, HH1a; S42318, pR hum, HH1a; S42276, pR hum, Croc Site L1.
ETYMOLOGY. Named for its extremely small size.

DiAGNOSIS. A very small species of Manuherikia in which the humerus shaft does not narrow distally.

REFERRED MATERIAL. Several coracoids are referred to M. minuta on the basis of size and form. They are a small version of those referred to $M$. lacustrina, which unlike those of all other anatids in the fauna lack pneumatic foramina in the acrocoracoid. The referred bones, MNZ S42320, S42803 and S42804 (Fig. 6A), from HH1a, are small (Table 3), have the acrocoracoid slightly overhanging the medial margin, lack pneumatic foramina in the supracoracoidal sulcus or under the acrocoracoid, lack a fossa within the supracoracoidal sulcus adjacent to or extending under the humeral facet, have the dorsal lobe of the clavicle facet slightly overhanging the supracoracoidal sulcus and the ventral surface of the blade is slightly concave.

Other specimens referred principally by size include: MNZ S42345, R ulna, Croc Site L1, length 49.87 mm; MNZ S42319, dR ulna, HH1a; MNZ S42280, pR ulna, Croc Site L1; MNZ S42278, R cmc, length $32.4 \mathrm{~mm}$, Croc Site L1; MNZ S42279, R scap, Croc Site L1; MNZ S42277, dL fem, Croc Site L1;

MEASUREMENTS. See Table 3.

REMARKS. Manuherikia minuta is slightly smaller and has the same postcranial skeletal proportions as the pink-eared duck Malacorhynchus membranaceus, but it differs in that the humerus has a more prominent capital shaft ridge and a deeper brachial fossa, while on the coracoid the clavicle facet is not as well developed as it is in Malacorhynchus. Manuherikia minuta differs most significantly from $M$. lacustrina, which was interpreted as a diver, in smaller size and that the shaft has parallel sides rather than narrowing distally. Other fossil postcranial elements of a small anatid presumably belong to M. minuta. These include ulnae (MNZ S42345, S42319) and carpometacarpi (MNZ S42278), which show no signs of their being from a flightless bird or one of reduced flight ability, as well as leg bones (e.g. distal femur MNZ S42277, distal tibiotarsi MNZ S42757, 42805, tarsometatarsus MNZ S42636), that are of appropriate size for a tiny duck. So we interpret the type series of $M$. minuta as being from a tiny volant duck rather than the reduced elements of a larger flightless form. Apart from the femur having a relatively deep popliteal fossa, available specimens

Table 3 Measurements ( $\mathrm{mm}$ ) of humeri (hum) and coracoids (cor) of Manuherikia minuta sp. nov.

\begin{tabular}{llllllll}
\hline Site & Cat No. MNZ S & Element & TL & PW & Depth ch & SW max & SW min \\
\hline HH1a Holotype & 42317 & L hum & 50.4 & 11.1 & 3.7 & 3.9 & 3.3 \\
HH1a & 42318 & pR hum & - & 11.6 & 4.0 & - & - \\
Croc Site L1 & 41067 & pR hum & - & $10.8^{*}$ & 3.6 & - & - \\
Croc Site L1 & 42276 & pR hum & - & $11.4^{*}$ & 3.7 & - & - \\
HH1a & 40472 & dL hum & - & - & - & - & - \\
Croc Site L1 & 42809 & R hum & $\sim 53$ & - & $3.4+$ & 4.1 & 3.7 \\
& MNZ S & Element & ML & L hf & SW & & - \\
HH1a & 42803 & L cor & 28.3 & 6.2 & 3.3 & & \\
HH1a & 42804 & R cor & 27.7 & 6.3 & 3.3 & & \\
HH1a & 42320 & pR cor & - & 6.2 & 3.0 & & \\
\hline
\end{tabular}

d, distal. For all other abbreviations, see Table 2. 
do not permit knowledge of whether this small duck had other morphological features associated with diving forms, e.g. dorsoventrally bent shaft of femur, anteriorly flattened tibiotarsus with elevated cnemial crests.

\section{Subfamily TADORNINAE Reichenbach, 1849-1850 Tribe TADORNINI (Reichenbach, 1849-1850)}

The following taxon is referred to Tadornini as the humerus has the unique combination of characters, in part listed by Woolfenden (1961): (1) humerus elongate, being only more so in Biziura, Dendrocygna, Thalassornis, anserines and more primitive anatids; (2) capital shaft ridge prominent and directed towards ventral side of a markedly elevated external tuberosity; (3) relatively narrow dorsal pneumotricipital fossa that does not undercut the head; (4) deltoid crest flaring and dorsally concave, elongate, extending well distad of bicipital crest; (5) ventral pneumotricipital fossa highly pneumatic, opening to bone interior; (6) the attachment point for the superficial pronator muscle is located, centrally to slightly cranial of centre, on the ventral facies level with the top of the facet for the attachment of the anterior articular ligament. Character (2) is here considered to be derived in Tadornini, with the plesiomorphic condition of the capital ridge directed towards the head in Anhimidae and Anseranatidae, the sister taxa of Anatidae, and only in Dendrocygna and Thalassornis within Anatidae. Character (3) is also derived in Tadornini, with the plesiomorphic condition (absence of a flattened dorsal pneumotricipital fossa) in Anhimidae, Anseranatidae, Dendrocygna and Thalassornis. Character (5) is considered to be a retained plesiomorphic character as seen in Anhimidae, Anseranatidae and, Dendrocygna, however, the size of the fossa is much enlarged compared with these taxa. Characters (1), (4) and (6) are retained plesiomorphic features.

\section{Genus MIOTADORNA gen. nov.}

TYPE SPECIES. Miotadorna sanctibathansi gen. et sp. nov., by monotypy.

ETYMOLOGY. To reflect our view that this anatid is a Miocene shelduck similar to Tadorna.

DiAGNOSIS. A tadornine the size of Tadorna variegata in which the humerus has a relatively smaller and much shallower ventral pneumotricipital fossa that is more occluded internally, by pneumatic bone, than in other tadornines pneumatic bone extends from the interior to the level of the crus dorsale fossae; crus dorsale fossa short, ending well proximad of level that bicipital crest joins to shaft, unlike Tadorna where both ridges end level with each other on the shaft; capital shaft ridge very well developed and separated from the dorsal tubercle by a deep distally-flaring groove; the brachial depression is deepest in the ventro-distal portion; the shaft between the brachial depression and the ventral margin is rounded and wider than the facet for the attachment of the anterior articularis ligament.

REMARKS. The modern tadornines Tadorna variegata, $T$. tadornoides (Jardine \& Selby, 1828), T. radjah (Lesson, 1828) and T. tadorna (Linnaeus, 1758) all differ substantially from Miotadorna in that their humeri have a much more pneumatic ventral pneumotricipital fossa, with bone struts no closer to the opening than below the capital shaft ridge. The capital shaft ridge is sharper proximally in the fossil taxon so that there is a distinct groove between it and the dorsal tubercle that is not present in modern tadornines. In Tadorna, the brachial fossa is shallow and flat, separated from the medial margin by a narrow ridge. The three tadornines in the Australasian region were separated generically by Livezey $(1997 a, b)$, with the two larger taxa, T. tadornoides and T. variegata, being placed in the unbanded shelduck subgenus Casarca Bonaparte, 1838 and T. radjah being left in Tadorna. We leave all in Tadorna following Dickinson (2003).

The African sheldgoose Alopochen aegyptiacus (Linnaeus, 1766) has humeri with a more marked concavity of the dorsal surface of the deltoid crest and a weaker capital shaft ridge than in Tadorna and Miotadorna. As in other modern tadornines it has a highly pneumatic ventral pneumotricipital fossa. Alopochen differs from Tadorna and is similar to Miotadorna in that the brachial depression is relatively small, centrally placed and is separated from the ventral facies by a broad rounded surface wider than the facet for the attachment of the anterior articular ligament, however not markedly deeper in its distomedial part as it is in Miotadorna.

Of the South American sheldgeese, only bones of Chloephaga picta (Gmelin, 1789) were examined. Livezey $(1997 a, b)$ found that Chloephaga and Alopochen formed the sister group to the shelducks in Tadorna inclusive of Casarca, but the relationship of the three genera was not resolved by Donne-Goussé et al. (2002). Humeri of Chloephaga have a very weak capital shaft ridge, with the shaft slightly compressed adjacent to the angle of the deltoid crest but wellrounded from there proximally, and so differ markedly from those of Tadorna and Alopochen aegyptiacus. Otherwise, they are similar to other tadornines.

\section{Miotadorna sanctibathansi gen. et sp. nov. (Figs 7A, D, 8A, D, 9A, B)}

HolOTYPE. MNZ S42794, R humerus, complete but for slight erosion of bicipital crest and, distally, the articular facet for the anterior ligament is broken and the proc. flexorius is lacking its caudal margin (Figs 7A, 8A).

TYPE LOCALITY AND HORIZON. Home Hills Station, Site 1a (HH1a), true left side Manuherikia River, Otago, New Zealand, $44^{\circ} 54^{\prime} 29^{\prime \prime} \mathrm{S}$; $169^{\circ} 51^{\prime} 30^{\prime \prime} \mathrm{E}$. Bed HH1a, a sand layer 6.88-7.0 $\mathrm{m}$ above the base of the Bannockburn Formation, Manuherikia Gp, Early-Middle Miocene, 16-19 Ma.

Distribution. Layer HH1a; Croc Site L1, Mata Creek, Otago, New Zealand.

MEASUREMENTS OF HOLOTYPE. Length $=122.9 \mathrm{~mm}$, proximal width $=25.2 \mathrm{~mm}$, depth of caput humeri $=8.42 \mathrm{~mm}$, mid-shaft widths $=9.58 \times 8.03 \mathrm{~mm}$, distal width $=$ $17.48 \mathrm{~mm}$, depth of dorsal condyle $=10.14 \mathrm{~mm}$.

PARATYPES. MNZ S42272, R hum, Croc Site L1; MNZ S42273, R hum, Croc Site L1; MNZ S42274, pR hum, Croc Site L1; MNZ S42275, dL hum, Croc Site L1.

ETYMOLOGY. From the fact that this bird used to live in the environs of the old gold mining centre of St Bathans near which the fossil sites are located. 
A

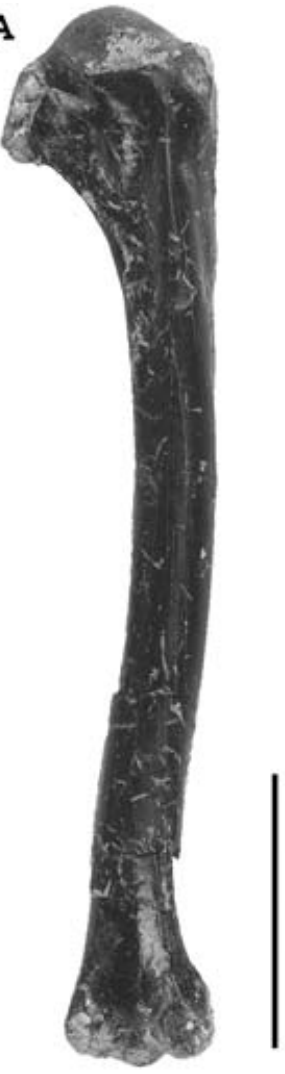

B

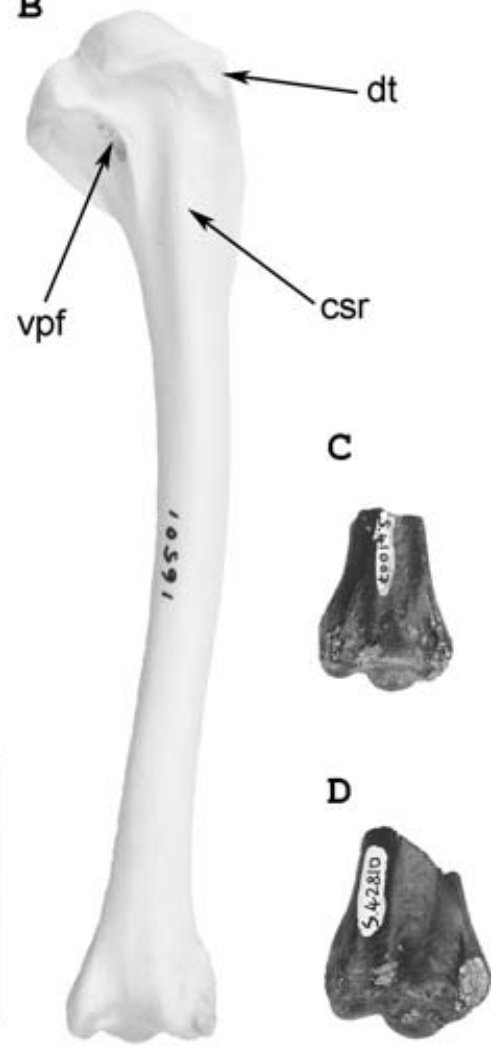

Figure 7 Comparison of fossil and Recent anatid humeri in caudal view: A, Miotadorna sanctibathansi gen. et sp. nov., holotype MNZ S42794; B, Tadorna variegata MNZ 16501, Recent; C, Dunstanetta johnstoneorum gen. et sp. nov., holotype MNZ S41007; D, M. sanctibathansi gen. et sp. nov., MNZ S42810. Abbreviations: csr, capital shaft ridge; $\mathrm{dt}$, dorsal tubercle; vpf, ventral pneumotricipital fossa (open, pneumatic). Scale bar $=30 \mathrm{~mm}$.

DiAGNOSIS. As for the genus.

REFERRED MATERIAL. MNZ S42313 dR hum, HH1a; MNZ S42234, L hum, Croc Site L1; MNZ S42810, dL hum, Croc Site L1 (Figs 7D, 8D); MNZ S42796, dR hum, HH1a.

MNZ S40093, R cor, HH1a; MNZ S42271, L cor, Croc Site L1; MNZ S42217, R cor, Croc Site L1; MNZ S42235, R cor, Croc Site L1; MNZ S42808, R cor, Croc Site L1 (Fig. 9A); MNZ S42795, R cor, HH1a (Fig. 9B).

\section{MEASUREMENTS. See Tables 4 and 5.}

REMARKS. The range in size of the fossil humeri indicates that Miotadorna had marked sexual size dimorphism as seen in modern tadornines.

A series of coracoids is referred to Miotadorna on the basis of expected size relative to the humeri and form. Assuming the fossil taxon had coracoids proportioned as in Tadorna variegata, the length of the four fossil humeri for which estimation of total length is possible indicates a coracoid medial length range of $48.7-53.7 \mathrm{~mm}$ (conversion ratio is 0.4269; for T. variegata data, see Table 6), or length from the procoracoid to the sternal facet with a range of $34.7-38.1 \mathrm{~mm}$ (conversion ratio is 0.3027; for $T$. variegata data, see Table 6).

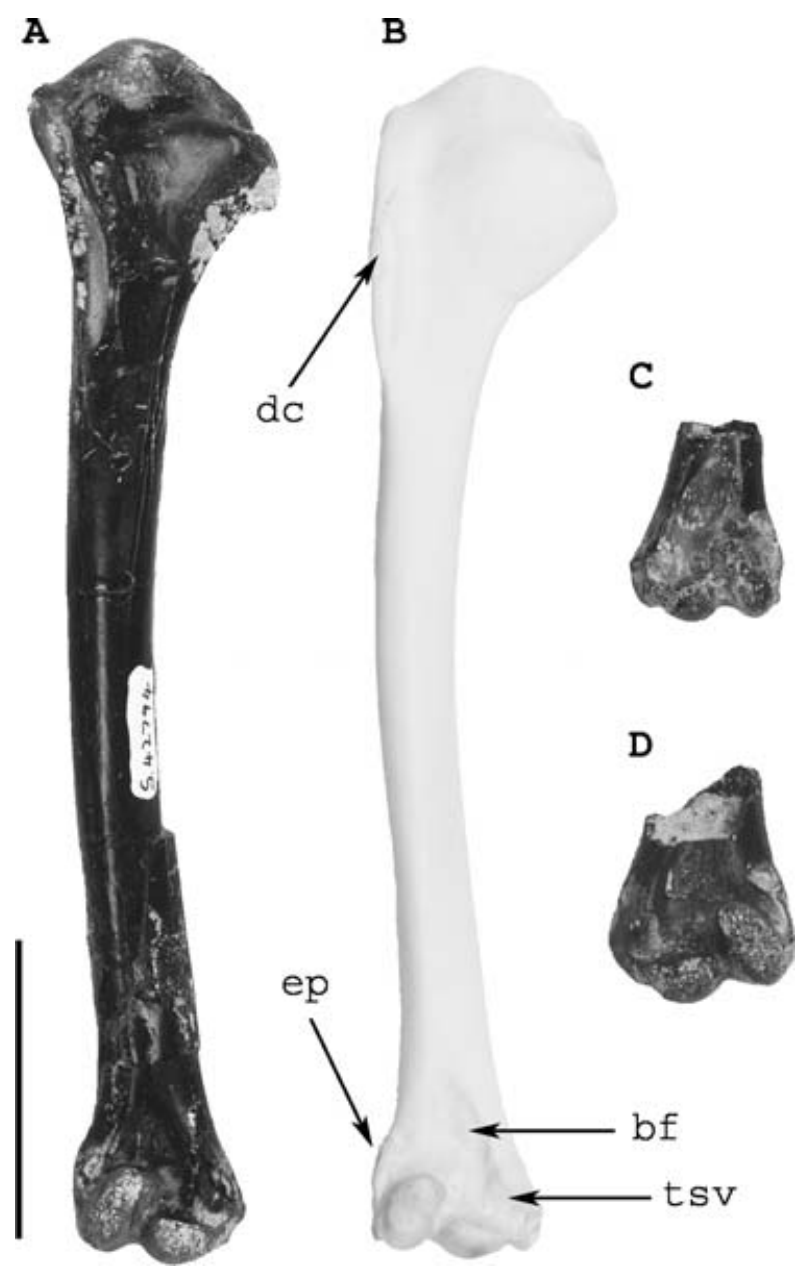

Figure 8 Comparison of fossil and Recent anatid humeri in cranial view: A, Miotadorna sanctibathansi gen. et sp. nov., holotype MNZ S42794; B, Tadorna variegata MNZ 16501, Recent; C, Dunstanetta johnstoneorum gen. et sp. nov., holotype MNZ S41007; D, M. sanctibathansi gen. et sp. nov., MNZ S42810. Abbreviations: bf, brachial fossa; dc, deltoid crest; ep, ectepicondylar process; tsv, tubercle for attachment of anterior articular ligament. Scale bar = $30 \mathrm{~mm}$.

Smaller and larger distal humeri (Table 4) indicate a probable greater range in coracoid size. We suspect that fossil coracoids with medial lengths of $46.4,47.4$ and $\sim 53 \mathrm{~mm}$ and lengths from the procoracoid to the sternal facet of 33.6$38.6 \mathrm{~mm}$ (Table 5) are also Miotadorna. A worn specimen (MNZ S40456) has a medial length of about $58 \mathrm{~mm}$ and may represent a maximum size for Miotadorna. Like tadornines, in these fossil coracoids the procoracoidal process is robust and short without a foramen and is not rotated ventrally, the acrocoracoid slightly overhangs the shaft medially and the least shaft width is towards the humeral end of the mid point. They differ from all modern tadornines, except Alopochen, in that they have an open pneumatic foramen penetrating the proc. acrocoracoideus between the dorsal and ventral lobes of the facies artic. clavicularis. Other features include: (1) a prominent dorsal lobe of the clavicle facet that forms the anterior boundary to the supracoracoidal sulcus; (2) a supracoracoidal sulcus not excavated under the humeral facet; 
Table 4 Measurements ( $\mathrm{mm}$ ) for humeri (hum) of Miotadorna sanctibathansi gen. et sp. nov.

\begin{tabular}{|c|c|c|c|c|c|c|c|c|c|c|}
\hline Site & Cat No. MNZ S & Element & $\mathrm{TL}$ & PW max & PW dt-bc & Depth ch & SW max & SW min & DW & Depth dc \\
\hline Croc L1 & 42234 & L hum & 125.8 & - & 19.1 & 8.3 & 10.2 & 8.8 & 19.6 & - \\
\hline Croc L1 & 42272 & R hum & 114.0 & - & 18.4 & 8.4 & 8.6 & 7.5 & - & 9.5 \\
\hline Croc L1 & 42273 & R hum & 119.4 & - & 17.4 & - & 8.3 & 6.9 & 16.5 & - \\
\hline Croc L1 & 42274 & pR hum & - & 23.3 & 18.1 & 8.2 & - & - & - & - \\
\hline Croc L1 & 42275 & dL hum & - & - & - & - & - & - & 17.9 & 10.2 \\
\hline Croc L1 & 42810 & dL hum & - & - & - & - & - & - & 18.8 & 10.6 \\
\hline $\mathrm{HH}_{1} \mathrm{a}$ & 40475 & pL hum & - & - & - & 8.4 & - & - & - & - \\
\hline HH1a Holotype & 42794 & R hum & 122.9 & 25.2 & 18.8 & 8.4 & 9.6 & 8.0 & $17 \cdot 5$ & 10.1 \\
\hline $\mathrm{HH}_{1} \mathrm{a}$ & 42796 & $\mathrm{dR}$ hum & - & - & - & - & - & - & 18.1 & 10.2 \\
\hline $\mathrm{HH}_{1} \mathrm{a}$ & 42313 & $\mathrm{dR}$ hum & - & - & - & - & - & - & 15.8 & - \\
\hline
\end{tabular}

TL, total length; PW max, maximum proximal width; PW dt-bc, proximal width from dorsal tubercle to bicipital crest; Depth ch, depth caput humeri; SWmax, maximum shaft width at mid-length; SWmin, minimum shaft width in caudal view; DW, greatest distal width; Depth dc, depth dorsal condyle.

Table 5 Measurements for coracoids (cor) referred to Miotadorna gen. nov.

\begin{tabular}{lllllllll}
\hline Site & Cat No. MNZ S & Element & Cor L1 & Cor L2 & Cor L3 & Cor L4 & W hum fac & W scap cotyla \\
\hline Croc Site L1 & 42271 & L cor & - & 35.2 & 11.1 & 35.0 & 6.1 & 4.4 \\
Croc Site L1 & 42217 & R cor & 47.4 & 34.4 & 12.2 & 34.7 & 6.4 & 4.5 \\
Croc Site L1 & 42235 & R cor & - & 35.9 & 11.9 & 36.3 & 6.9 & 5.4 \\
HH1a & 40093 & R cor & - & 37.9 & $\sim 12.0$ & - & 6.9 & 4.6 \\
HH1a & 42795 & R cor & 46.4 & 33.6 & 11.9 & 33.9 & 6.8 & 4.5 \\
Croc Site L1 & 42808 & R cor & $\sim 53$ & 38.6 & 14.0 & - & 7.3 & 5.7 \\
\hline
\end{tabular}

Abbreviations: Cor L1, medial length from acrocoracoid to medial angle; Cor L2, length from procoracoid by scapular cotyla along the medial facies to sternal facet; Cor L3, length from scapular cotyla to the top of the humeral facet; Cor L4, length from procoracoid by scapular cotyla to the medial angle; W hum fac, width of humeral facet; W scap cotyla, width of scapular cotyla.

Table 6 Summary statistics for measurements $(\mathrm{mm})$ of Tadorna variegata and data for other modern species (specimens listed on pp. 6-7, Comparative Material).

\begin{tabular}{|c|c|c|c|c|c|c|c|c|c|c|}
\hline & Hum L & Hum PW & Hum PW 2 & Hum SW & Hum DW & Cor L1 & Cor L2 & Cor L3 & Cor L1/humL & Cor L2/humL \\
\hline Mean & 126.4 & 25.4 & 19.5 & 8.6 & 18.3 & 53.5 & 37.9 & 13.4 & 0.427 & 0.303 \\
\hline Standard Deviation & 6.32 & 1.28 & 1.05 & 0.42 & 1.03 & 2.67 & 1.77 & 0.67 & 0.007 & 0.006 \\
\hline Minimum & 118.6 & 23.6 & 18.1 & 7.9 & 16.8 & 49.7 & 35.2 & 12.7 & 0.416 & 0.294 \\
\hline Maximum & 136.7 & 26.9 & 20.8 & 9.2 & $19 \cdot 5$ & 57.1 & 40.5 & $14 \cdot 3$ & 0.436 & 0.311 \\
\hline Count & 11 & 11 & 11 & 11 & 11 & 10 & 10 & 10 & 10 & 10 \\
\hline T. tadornoides ANWC 22240 & 113.8 & 24.7 & - & 8.0 & 18.0 & 51.4 & - & - & 0.452 & - \\
\hline T. tadornoides MNZ 27367 & 125.9 & $27 \cdot 3$ & 20.1 & 8.5 & 19.1 & 56.8 & 40.0 & 14.2 & 0.451 & 0.318 \\
\hline T. tadorna & 101.8 & 21.8 & 15.2 & 7.8 & 15.0 & 47.5 & 33.8 & 12.5 & 0.467 & 0.332 \\
\hline
\end{tabular}

Abbreviations: Hum L, length of humerus; Hum PW, proximal width of humerus in the latero medial plane; Hum PW2, humerus width from dorsal tubercle to the end of the humeral head; Hum SW, shaft width at midlength; Hum DW, distal width of humerus; Cor L1, medial length from acrocoracoid to medial angle; Cor L2, length from procoracoid by scapular cotyla along the medial facies to sternal facet; Cor L3, length from scapular cotyla to the top of the humeral facet.

(3) a moderately inflated ventral edge to the supracoracoidal sulcus; (4) an acute medial angle; (5) ventrally the blade is convex and bound laterally by a weak ridge; (6) the ventral sternal facet is not prominent. Measurements are given in Table 5, with the size range indicated by specimens in Figs $9 \mathrm{~A}$ and $9 \mathrm{~B}$.

Coracoids of Tadorna differ from the fossil in that they do not have a pneumatic foramen penetrating the acrocoracoid, the ventral surface of the sternal blade is flattened, not convex, and the ventral sternal facet is prominent. In $\mathrm{Ta}$ dorna variegata, T. tadornoides and T. tadorna, but not in T. radjah, the supracoracoidal sulcus is excavated under the humeral facet as well as under the ridge leading to the clavicle facet and the dorsal lobe of the clavicle facet is prominent and overhangs the supracoracoidal sulcus. In T. radjah, the clavicle facet is less prominent, the acrocoracoid does not overhang the shaft medially and the shaft is slender.

Coracoids of Alopochen, unlike all other extant tadornines, have an area of pneumatic foramina, rather than a discrete single foramen, within the acrocoracoid that is centred under the dorsal lobe of the clavicle facet rather than between the dorsal and ventral lobes of that facet. As a result, the dorsal lobe of the clavicle facet does not obstruct the extension of the supracoracoidal sulcus under the head 


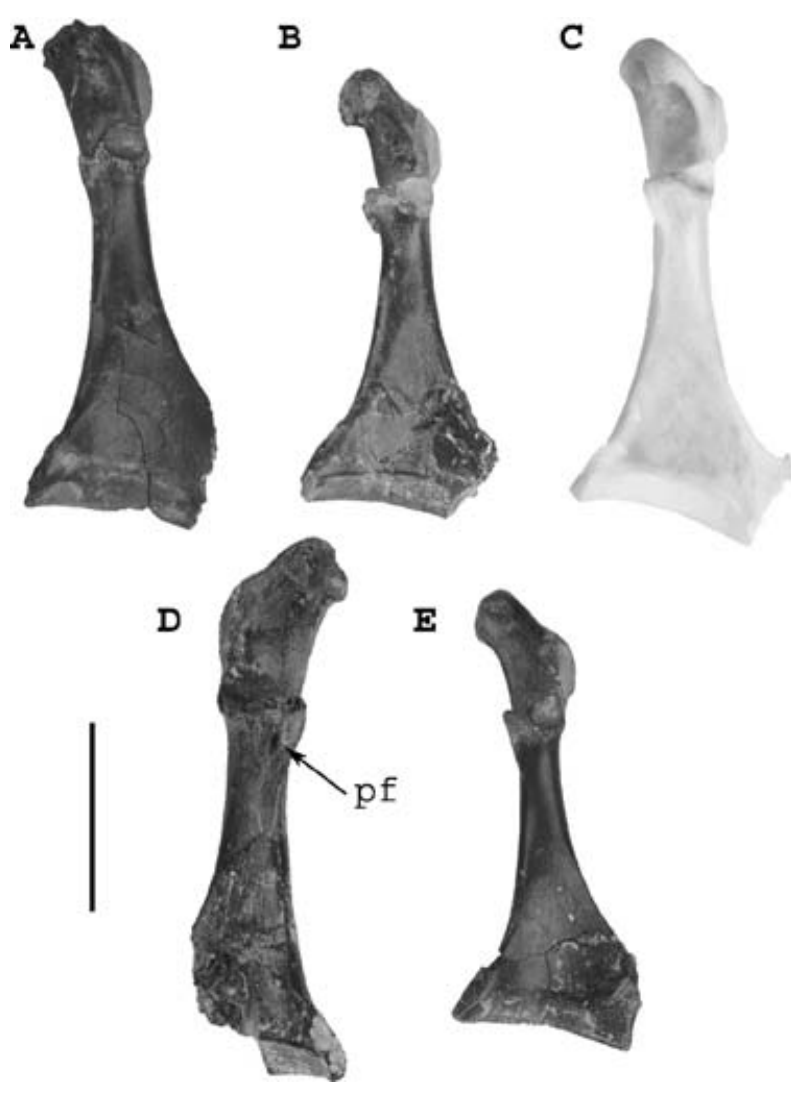

Figure 9 Comparison of fossil and Recent anatid coracoids as follows: A, Miotadorna sanctibathansi gen. et sp. nov., MNZ S42808; B, M. sanctibathansi gen. et sp. nov., MNZ S42795; C, Tadorna variegata MNZ 16501, Recent; D, anatid subfamily undetermined MNZ S42797; E, Dunstanetta johnstoneorum gen. et sp. nov., paratype MNZ S42481. Abbreviations: pf, procoracoidal foramen. Scale bar $=$ $20 \mathrm{~mm}$.

as it does in Miotadorna. Otherwise coracoids of Alopochen differ from the fossil in that the supracoracoidal sulcus has a marked excavation under the humeral facet and its medial edge is thick, the ventral sternal facet is prominent and the ventral face of the blade is flat not convex. Coracoids of Chloephaga lack pneumatic foraminae in the acrocoracoid.

\section{Anatidae, Subfamily undetermined}

The presence of an anatid larger than Miotadorna sanctibathansi is indicated by a left coracoid, MNZ S42797, that is larger (length $=57.5 \mathrm{~mm}, \mathrm{SW}=7.16 \mathrm{~mm}$, scapular facet top humeral facet $=14.3 \mathrm{~mm}$ ) than those referred to Miotadorna. It also differs markedly by the presence of a well defined procoracoidal foramen and in having a proportionally larger humeral end so that least shaft width is at mid length, rather than closer to the humeral end (Fig. 9D). The shape of the fossil is similar to that of anserines and it shares with Cereopsis and Cnemiornis the presence of a procoracoidal foramen (otherwise found only in anhimids and Anseranas among extant anseriforms), but it differs from all anserines and also Miotadorna in that it lacks a large pneumatic foramen penetrating the acrocoracoid under the clavicle facet. There is instead a very small foramen below the dorsal clavicle facet. The fossil coracoid differs markedly from that of Anseranas, which is of similar size and robustness, in that the procoracoid is relatively smaller, the procoracoidal foramen does not open to the shaft interior, dorsally the blade lacks a large pneumatic fossa (that is also present in anhimids) and medially the margin is compressed to a thin flange and is not thick above the medial angle. At present the affinities of this anatid are unknown.

The other specimen listed below is of similar size and may represent this taxon or a large specimen of Miotadorna, but is too worn to determine whether a procoracoidal foramen is present. At the present time, no humeri are known that are of appropriate size for the taxon represented by this coracoid. The existence of this anatid, which is slightly larger than Miotadorna, reveals the probability that not all other skeletal elements of large anatids would necessarily be correctly referred to Miotadorna.

MATERIAL. MNZ S42797, L coracoid, HH1a. Possibly MNZ S40456, worn R coracoid, HH1a.

\section{Subfamily ?ANATINAE Leach, 1820 Tribe incertae sedis Genus DUNSTANETTA gen. nov.}

TYPE SPECIES. Dunstanetta johnstoneorum gen. et sp. nov., by monotypy.

ETYMOLOGY. After the high mountain range that overlooks the fossil site.

DIAGNOSIS. An anatid distinguished from all other anatids by the following suite of characters. It is the size of Stictonetta or smaller individuals of Miotadorna. The humerus has a broad flat impression of $m$. brachialis anticus in a shallow brachial depression that extends close to the ventral margin of the bone, such that the intervening shaft width is less than half the width of the facet for the attachment of the anterior articular ligament. The ventral facies of the humerus is essentially flat and at right angles to the plane of the adjacent brachial depression, with the attachment for the superficial pronator muscle forming a large deep pit, more so than in any compared taxa, centrally located and extending from a point level with, to a point slightly proximad of, the top of the facet for the attachment of the anterior articular ligament. The coracoid has the acrocoracoid penetrated by a single large pneumatic foramen located between the ventral and dorsal lobes of the clavicle facet, which is thus notched; the shaft is slender; the medial angle is acute. The tarsometatarsus is relatively short with proportions similar to that of Somateria or Mergus serrator, it has broad ends and a narrow shaft that is about as wide as deep and trochlea II is strongly recurved plantarly.

REMARKS. Among anatids, only anserines, some tadornines (Alopochen and Miotadorna), Aix, Cairina and Callonetta leucophrys (Vieillot, 1816) have pneumatic foramina penetrating the acrocoracoid (Livezey, 1991). In Cairina and Aix (although some individuals of $A$. galericulata lack any foramina e.g. MNZ 27368), the area of pneumatic foramina is large and extends under the whole acrocoracoid. In Alopochen the foramen lies under the dorsal clavicle facet and Miotadorna is similar to Dunstanetta with the foramina 
between the lobes of the clavicle facet. The narrow shaft of the coracoid and the short tarsometatarsus with expanded ends and recurved trochlea for digit 2 in Dunstanetta is, however, unlike that in any anserine or tadornine. The absence of a proximal end to the humerus precludes any further refinement of the relationships of this taxon intergenerically.

\section{Dunstanetta johnstoneorum gen. et sp. nov. (Figs 7 C, 8C, 9E)}

HoLOTYLE. MNZ S41007, distal L humerus (Figs 7C, 8C).

LOCALITY AND HORIZON. Home Hills Station, Site 2 (HH2), true left side Manuherikia River, Otago, $\left(44^{\circ} 54^{\prime} 28^{\prime \prime}\right.$ S; $169^{\circ}$ $51^{\prime} 30^{\prime \prime}$ E). Bed HH2c, $c a .17 \mathrm{~cm}$ thick sand layer about $21.3 \mathrm{~m}$ above the base of the Bannockburn Formation, Manuherikia Group, Early-Middle Miocene, 19-16 Ma.

MEASUREMENTS OF HOLOTYPE. Distal width $=15.4 \mathrm{~mm}$, shaft width at proximal end of brachial fossa $=9.1 \mathrm{~mm}$, depth of dorsal condyle $=9.3 \mathrm{~mm}$.

PARATYPES. MNZ S42481 a complete R cor (Fig. 9E), MNZ S42482 R ulna, MNZ S42483 L tmt lacking distal end, MNZ S42484 R tmt, MNZ S42485 pedal phalanx RII.1; all from $\mathrm{HH} 2 \mathrm{a}$.

ETYMOLOGY. Named after Ann and Euan Johnstone of Home Hills Station, on which the type locality lies.

DiAGNOSIS. As for the genus.

COMPARATIVE DESCRIPTION. The preserved elements of Dunstanetta show that, compared to other Manuherikia anatids, it is larger than the species of Manuherikia and the following taxon (Matanas) and smaller than Miotadorna or the undetermined taxon described above.

The humerus of Dunstanetta has a uniquely deep and large point of attachment for the superficial pronator muscle. However, the other features, such as a shallow brachial depression with the adjacent medial surface at right angles to it, are individually seen in many diverse anatid taxa: e.g. Tadorna, Stictonetta, Somateria, Chenonetta and some Anas spp. The ventral epicondyle of Dunstanetta is short and broad with the attachment for the superficial pronator muscle centrally located on the ventral surface, as seen in Cairina, but unlike in Somateria and Mergus where the ventral epicondyle is very elongate and the pit for attachment for the superficial pronator muscle is located towards the cranial side. In the more specialised divers Oxyura and Biziura, the pit is indistinct and lies at the cranial margin of the ventral facies and the epicondyle is even more elongate.

In Miotadorna, for which some examples of distal humeri are only slightly larger than Dunstanetta, the brachial depression is deeper and more widely separated from the medial margin and the attachment for the superficial pronator muscle is a shallower pit.

The associated coracoid, apart from having a pneumatic acrocoracoid, has the following unique combination of characters: the ventral and dorsal lobes of the clavicle facet are separated by a notch; the acrocoracoid is compressed lateromedially and overhangs the shaft medially; the dorsal clavicle facet is not protuberant into the supracoracoidal sulcus; the ventral medial edge of the supracoracoidal sulcus is thin; the supracoracoidal sulcus is not excavated under the humeral facet; there is no procoracoidal foramen; the medial angle is acute; the ventral surface of the sternal end is evenly convex with no ridge along the lateral side; the dorsal sternal facet is broad and extends over most of the blade width, but the ventral sternal facet is small. The acrocoracoid is only pneumatic in Cairina, Aix, Callonetta leucophrys, some tadornines (such as Miotadorna and Alopochen) and Cereopsis and other anserines, however, the broad sternal end and narrow shaft of the coracoid of the fossil is unlike that of these taxa. In most diving ducks (Oxyura, Biziura, Aythya, Mergus, Somateria) the acrocoracoid does not overhang the shaft medially as it does in the fossil. The fossil coracoid has neither the deep fossa on the ventral surface of the sternal end found in Dendrocygna, Thalassornis and Stictonetta, nor the shallow one of Mionetta, Oxyura, Nettapus, Malacorhynchus and Hymenolaimus. In Mionetta, the acrocoracoid is not pneumatic, the dorsal lobe of the clavicle facet protrudes into or overhangs the supracoracoidal sulcus, the ventral surface of the sternal blade has a marked hollow in it and the ventral sternal facet is prominent.

The associated tarsometatarsi have similar proportions to those of Somateria mollissima. They feature a narrow shaft about as wide as deep with abruptly expanded ends; the extensor sulcus, deep proximally and extending to about mid-length, is bound by a ridge laterally but not medially; the trochlea II is rotated plantar-caudally to the extent that the whole articular surface is distad to TIII; the intercotylar knob does not extend above the cotylae. The narrow shaft differs markedly from the wider than deep state seen in Cairina, Stictonetta and Oxyura. The tarsometatarsus of Stictonetta is very different in that the extensor sulcus is deep, bound by high ridges both laterally and medially and extends distally to the foramen vasculare distale.

REFERRED MATERIAL. MNZ S41008, R fem lacking proximal end.

MEASUREMENTS. See Table 7. Measurements of coracoid (MNZ S42481): medial length $=46.0 \mathrm{~mm}$, length from scapula cotyla to top of acrocoracoid $=16.7 \mathrm{~mm}$, scapular facet to top of humeral facet $=11.4 \mathrm{~mm}$, width of humeral facet $=$ $5.9 \mathrm{~mm}$, shaft width $=4.4 \mathrm{~mm}$, width of sternal articulation $=$ $20.2 \mathrm{~mm}$.

REMARKS. The holotype and referred femur were found about 2 years before the associated type series but came from the same place. The paratype series was found in a $20 \mathrm{~cm}$ wide exposure of $\mathrm{HH} 2 \mathrm{c}$ and are probably parts of a single individual, which because of their uniqueness are associated with the holotype. The nearest bird bones elsewhere

Table 7 Measurements ( $\mathrm{mm}$ ) of Dunstanetta johnstoneorum gen. et sp. nov.

\begin{tabular}{lllllll}
\hline Element & Cat No. MNZ S & Length & PW & SW (min) & DW & Depth T3 \\
\hline Ulna & 42482 & 89.8 & 10.4 & 5.2 & - & - \\
Femur & 41008 & 51 (est.) & - & 4.4 & 12.5 & - \\
Tmt & 42483 & 46.1 & 11.1 & 4.6 & 10.8 & 7.6 \\
Hum & 41007 & - & - & - & 15.3 & - \\
\hline
\end{tabular}

PW, proximal width in the lateromodial plane; SW (min), minimum shaft width; DW, distal width; T3, trochlea III. 
in this layer were several metres distant. The femur is different to the common species in HH1a and as it is of appropriate size for the humerus, is referred to the present new species. It lacks the proximal end, but the shaft is narrow and dorsoventrally bent, it has a large deep popliteal fossa bound by a narrow ridge medially, while the distal end features a markedly expanded fibular condyle. The associated ulna has a deep impressio brachialis that forms a right angle with the medial facies but is otherwise unremarkable.

The above femoral characters and the short tarsometatarsus with strongly recurved TII are features normally associated with diving behaviours in anatids so Dunstanetta johnstoneorum was probably a diving duck. However, it differed from the highly specialised diving ducks, e.g. Oxyura, in not having a broad tarsus. The combined features of the coracoid distinguish it from all known anatids, but its proportions are more similar to anatines than anserines or tadornids. Similarly, the shortened tarsometatarsus of Dunstanetta, with a strongly recurved TII, is more like those of anatines than the more elongate bone of tadornines and anserines, in which TII and TIV have closer to equal distal extent. This combination of features suggests Dunstanetta may have affinity with anatids such as Chenonetta and Hymenolaimus or other anatines, exclusive of Aythya, Mergus and Oxyura, but its affinities remain obscure and will probably remain so until a proximal humerus is found.

\section{Subfamily ANATINAE Leach, 1820 Tribe ?ANATINI Leach, 1820 Genus MATANAS gen. nov.}

TYPE SPECIES. Matanas enrighti gen. et sp. nov., by monotypy.

ETYMOLOGY. A combination of the name of the creek, Mata, beside which the type locality lies and Anas, a duck. The gender is feminine.

DiAGNOSIS. An anatid about the size of Hymenolaimus malacorhynchos (Gmelin, 1789) defined by the following combination of features of the humerus: not elongate, proportioned as in Anas; deltoid crest concave dorsally; dorsal tubercle elevated; capital shaft ridge extends to beside dorsal tubercle; broad dorsal part to the pneumotricipital fossa; ventral pneumotricipital fossa pneumatic, opens internally; shaft does not taper distally; the brachial depression has a small narrow impression of brachialis anticus that forms a noticeable sulcus distomedially and is bound medially by a broad rounded ridge; the pit for the attachment of the superficial pronator muscle is proximad of the facet for the attachment of the anterior articular ligament and located centrally on the ventral facies; the attachment for anterior articular ligament is elevated and rotated distally; the ectepicondylar prominence extends well proximad of the dorsal condyle; the dorsal condyle in cranial view overlaps ventrally the ventral condyle on its proximal side to leave a relatively narrow space between it and the facet for the attachment of the anterior ligament.

REMARKS. That the humerus is not elongate precludes a close relationship with Anseranas, Dendrocygna and Thalassornis. The presence of a dorsal pneumotricipital fossa is derived with respect to Anseranas, Dendrocygna and Thalassornis. The open pneumatic ventral pneumotricipital fossa ex- cludes a close relationship of Thalassornis, Dendrochenines, Malacorhynchus, Oxyura, Biziura and Aythya (wherein all it is closed) with Matanas. The presence of the plesiomorphic features of a capital shaft ridge, concave deltoid crest and raised dorsal tubercle excludes a relationship with Anas and its near relatives, which all have the derived states (no capital shaft ridge, flat-convex deltoid crest, dorsal tubercle flush with shaft). The proportions of the humerus are similar to that found in Chenonetta or Anas and not elongate as in tadornines. Furthermore, the deltoid crest is relatively short and does not extend well distad of the bicipital crest as in tadornines, while the size of the humerus is smaller than all tadornines except Tadorna radjah.

The combination of humeral characters of prominent capital shaft ridge, concave deltoid crest, elevated dorsal tubercle and open ventral pneumotricipital fossa found in Matanas are also found in Stictonetta naevosa (Gould, 1841), Hymenolaimus and Chenonetta. However, in Matanas, the proc. supracondylaris dorsalis (ectepicondylar prominence), while lacking the projection seen in Dendrocygna, is located farther proximally than in Stictonetta or Hymenolaimus and is distinctly proximad of the dorsal condyle. Hymenolaimus further differs by the head being deeply excavated under its caudal surface resulting in the capital groove being interrupted by a distinct ridge at its dorsal end, whereas in Matanas the head is not undercut caudally, although the dorsal part of the pneumotricipital fossa is much deeper than the adjacent capital groove. In addition, Hymenolaimus has a wider space between the dorsal condyle and the facet for the anterior articular ligament.

Chenonetta shares with Matanas the proximal position of the ectepicondylar prominence, but differs as it has a weak capital shaft ridge in $C$. jubata (Latham, 1802), or one that is secondarily enhanced by flightlessness in $C$. finschi (Beneden, 1875), that does not extend up to beside the dorsal tubercle (Worthy \& Olson 2002). Also, in Chenonetta, the dorsal condyle does not overlap the ventral condyle in cranial view to the same extent, so that the space between it and the facet for the attachment of the anterior articular ligament is wider.

All three genera (Hymenolaimus, Chenonetta and Stictonetta) have been problematic as to their taxonomic placement. While Stictonetta is generally regarded as relatively primitive, both Hymenolaimus and Chenonetta are variably placed within or outside of anatines but are often allied to tadornines (Johnsgard 1968; Marchant \& Higgins 1990; Sraml et al. 1996; Livezey 1997b; Donne-Goussé et al. 2002; Worthy \& Olson 2002). Certainly, the proximal position of the ectepicondylar prominence in Matanas and Chenonetta is seen in Tadorna, but no other compared taxa. The available evidence suggests Matanas may be more closely related to Chenonetta among extant taxa and so could be a relatively primitive member of Anatini. However, discovery and referral of other elements will be crucial to the further refinement of the relationships of this taxon.

Matanas thus differs markedly from sympatric and similar-sized Manuherikia in the pneumatic ventral pneumotricipital fossa, lesser excavation of the dorsal part of the pneumotricipital fossa, by the brachial depression being separated from the medial margin by a broad rounded ridge and by the proximal location of the ectepicondylar prominence (sensu Howard 1929: fig. 20). Matanas enrighti is much smaller than Dunstanetta johnstoneorum. 
Matanas enrighti gen. et sp. nov. (Figs 4A, C, 5A, C, 6C)

HolOTYPE. MNZ S42281, left humerus with deltoid crest broken, crus dorsale fossae and the distal margin of the bicipital crest broken and the distal condyles worn (Fig. 4A, 5A).

LOCALITY AND HORIZON. Croc Site L1, in $3 \mathrm{~m}$ cliff north side of small hill left side Mata Creek, Otago, New Zealand, $\left(44^{\circ} 53^{\prime} 22^{\prime \prime} \mathrm{S} ; 169^{\circ} 50^{\prime} 16^{\prime \prime} \mathrm{E}\right)$. Layer 1 , a $10 \mathrm{~cm}$ thick siltysand layer, ca. $3.5 \mathrm{~m}$ above the Dunstan/Bannockburn contact, Manuherikia Group, early-Middle Miocene, 19-16 Ma.

DistRIBUTION. Croc Site L1; Layer HH1a, Manuherikia River, Otago.

MEASUREMENTS OF HOLOTYPE. Length $=84.8 \mathrm{~mm}$, depth of head $=6.3 \mathrm{~mm}$, mid-shaft width $6.2 \times 5.5 \mathrm{~mm}$, distal width $=11.8 \mathrm{~mm}$.

PARATYPES. MNZ S42704, dR hum, HH1a, (DW = $11.7 \mathrm{~mm}$, depth of dorsal condyle $=6.6 \mathrm{~mm}$ : Figs $4 \mathrm{C}, 5 \mathrm{C}$ ).

ETYMOLOGY. After Mr Jack Enright, who owns the station on which the type locality lies.

DiAgNOSIS. As for genus.

REMARKS. A single left coracoid (MNZ S42312, HH1a, Fig. 6C) represents an anatid about the size of Manuherikia lacustrina and smaller than Dunstanetta, so may belong to Matanas. This specimen is more robust and slightly shorter than those referred to $M$. lacustrina and differs from them as follows: the acrocoracoid markedly overhangs the medial margin, the dorsal and ventral lobes of the clavicle facet are not markedly notched, the supracoracoidal sulcus extends as a deep pneumatic pocket up under the dorsal clavicle facet; the shaft is robust and aligned markedly medially relative to the sternal facet, the ventral sternal facet is robust and prominent. Its measurements are: medial length $=37.2 \mathrm{~mm}$, length to top of procoracoid $=27.4 \mathrm{~mm}$, least shaft width $=$ $4.74 \mathrm{~mm}$, width sternal articulation $16.25 \mathrm{~mm}$. It differs markedly from most taxa, except Miotadorna and Dunstanetta, by the deep pneumatic pocket in the acrocoracoid and it differs from all tadornines by the acrocoracoid markedly overhanging the shaft medially and by its short stouter form. It further differs from dendrochenines, Stictonetta and Malacorhynchus in lacking a marked hollow on the ventral surface of the blade. While the pneumatic acrocoracoid is very different to the non-pneumatic state of Stictonetta, Hymenolaimus and Chenonetta as well as of Malacorhynchus, Matanas shares with these taxa the overhanging acrocoracoid.

\section{Order ACCIPITRIFORMES Vieillot, 1816 Family ACCIPITRIDAE Vigors, 1824}

\section{Genus and species indet. (Fig. 10A)}

MATERIAL. MNZ S42811, dL tibiotarsus, Croc Site L1, (Fig. 10A); MNZ S42490, dR ulna, HH2c.

MEASUREMENTS. MNZ S42811, DW = $14.2 \mathrm{~mm}$ (across condyles). MNZ S42490, SW maximum near distal end = $7.6 \mathrm{~mm}$, length cond. dorsalis ulnaris $=12.4 \mathrm{~mm}$, width

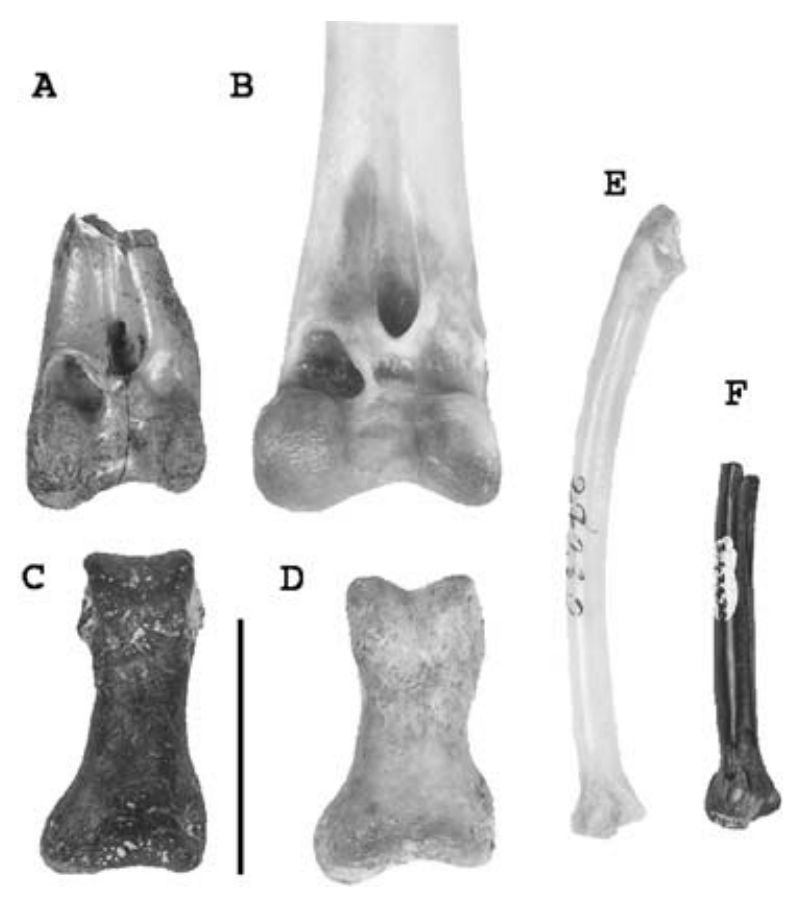

Figure 10 St Bathans fossils compared to Recent taxa. A, accipitrid genus and species indet. MNZ S42811, dL tib; B, Aquila audax MNZ 25643, dL tib, Recent; C, ?Aptornithid gen. et sp. indet. MNZ S42623 phalanx IV.1; D, Aptornis otidiformis MNZ S42995, phalanx IV.1, Holocene fossil; E, Macropygia amboinensis phasianella MNZ27230, R ulna, Recent; F, columbid gen. et sp. indet. MNZ S42430, dR ulna, $\mathrm{HH}_{1} \mathrm{a}$; Scale bar $=20 \mathrm{~mm}$.

dorsal ulnar condyle $=11.2 \mathrm{~mm}$. In ventral view the width across the sulcus intercondylaris $=9.0 \mathrm{~mm}$.

REMARKS. In cranial aspect MNZ S42811 is relatively unworn, but posteriorly the condyles are worn to the level of the intercondylar area. The side of the medial condyle is worn but the base of the central prominence is visible. This fragment is readily identified as an accipitrid tibiotarsus by the distinct shape of the pons supratendineus over the centrally placed canalis extensorius and the shallow depth of the condyles, but few features allowing generic attribution are preserved. The area laterad of the supratendinal bridge and above the lateral condyle has a distinct shallow fossa not found in Circus but seen in eagles (Aquila, Haliaeetus). In cranial view, the medial condyle extends proximally to a point medial of the extensor canal, whereas in Circus, Aquila and Haliaeetus it ends proximally with no overlap of the extensor canal. In size, this fossil represents an accipitrid about the size of a large female extinct Eyles's harrier Circus eylesi Scarlett, 1953 (e.g. MNZ S33635, tibiotarsus DW $=15.9 \mathrm{~mm}$ ) which is the largest known Circus species, but it is smaller than a male wedge-tailed eagle Aquila audax (Latham, 1802), e.g. MNZ 25956, tibiotarsus DW $=19.7 \mathrm{~mm}$.

The distal ulna MNZ S42490 is from an accipitrid and is shaped most like Aquila audax, especially in the more elongate dorsal ulnar condyle. It lacks pneumatic foramina as found in Gyps or Aegypius. Both Haliaeetus leucogaster (Gmelin, 1788), e.g. MNZ 27059, and the golden eagle Aquila chrysaetos (Linnaeus, 1758), e.g. MNZ 15894, have a relatively short dorsal ulnar condyle that is about as long 
A

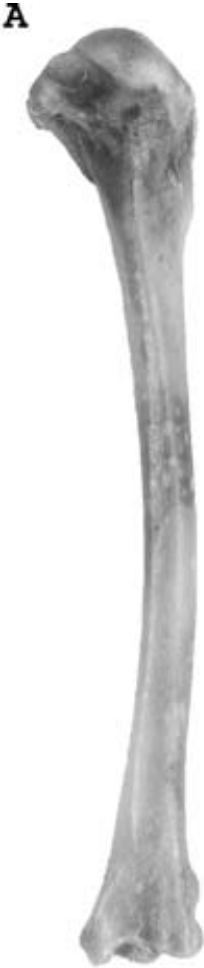

B
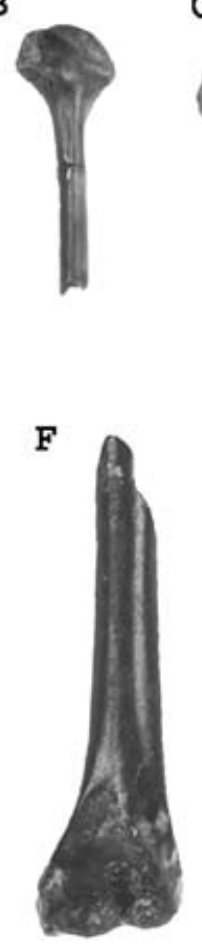

C

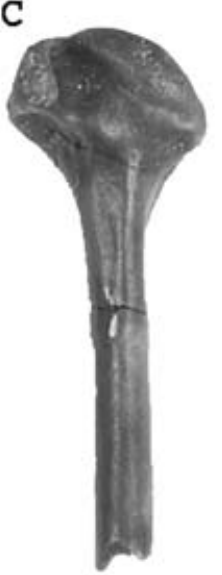

G

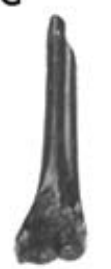

D

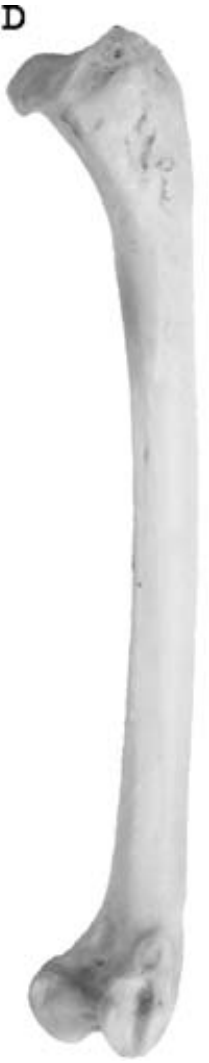

E

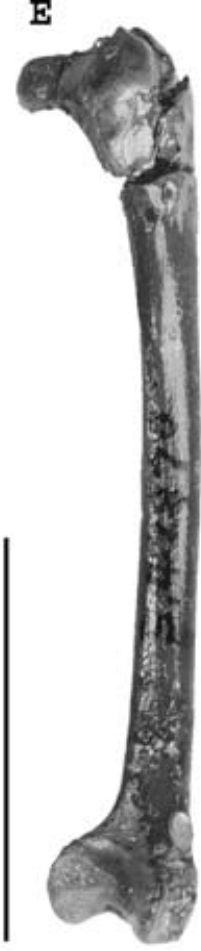

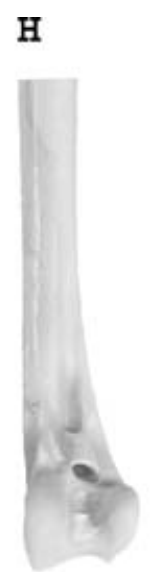

$\mathrm{K}$

I

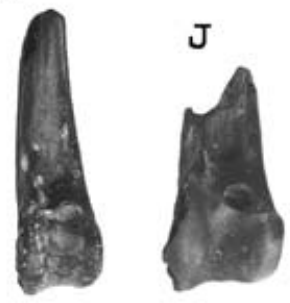

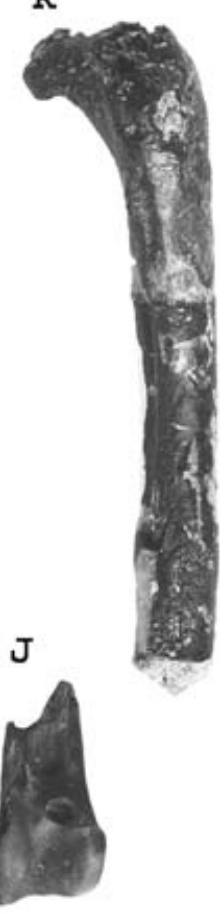

Figure 11 Comparison of fossil rail (Rallidae) bones (B, C, E, F, G, I, J, K) to those of a Recent individual Gallirallus philippensis assimilis MNZ 23800 (A, D, H). B, C, new sp. 1 pR hum, MNZ S42665; F, G, new sp. 1 dL hum, MNZ S42872; E, new sp. 1 R femur, MNZ S42870; I, new sp. 1 dR tt (small specimen), MNZ S42248; J, new sp. 1 dR tt (big specimen), MNZ S42869; K, new sp. 2 pR fem, MNZ 42638; Scale bar = 20 mm; C and F at 2x scale.

as it is wide. The incisura tendinosa is broad and long and thus more similar to Aquila than Circus, in which it is narrow. This fossil is from a larger bird than a large fossil Circus eylesi (MNZ S33635) but is smaller than a male Aquila audax (MNZ 25956).

Both fossils document the existence of an accipitrid larger than most Circus hawks but smaller than the wedgetailed eagle Aquila audax. Until more complete material is found and comparisons are possible with a wider array of Accipitridae, the relationships of this fossil will remain unknown.

\section{Order GRUIFORMES Bonaparte, 1854 Family ?APTORNITHIDAE Bonaparte, 1856}

\section{Genus and species indet. (Fig. 10C)}

MATERIAL. MNZ S42623, pedal phalanx R IV.1, HH1a (Fig. 10C).

MEASUREMENTS. $\mathrm{L}=25.7 \mathrm{~mm}, \mathrm{PW}=13.2 \mathrm{~mm}$, proximal height $=10.4 \mathrm{~mm}, \mathrm{DW}=8.4 \mathrm{~mm}$, distal height $=8.4 \mathrm{~mm}$.

REMARKS. This phalanx is proportionally shorter than those of all anatids, ciconiiforms and phoenicopteriforms and very different in shape to those of accipitrids. Its proportions are similar to this element in gruiforms and the shape of this specimen is very similar to that of the giant extinct Aptornis. It is slightly smaller than this phalanx in the North Island
Aptornis otidiformis (Owen, 1844) (Fig. 10D). We thus tentatively refer MNZ S42623 to the Aptornithidae.

\section{Family RALLIDAE Rafinesque, 1815 Genus indet.}

\section{New species 1 - magn. Gallirallus striatus or G. philippensis assimilis (Fig. 11B, C, E-G, I, J)}

MATERIAL. 115 elements. All specimens, except one femur (MNZ S42870) and two carpometacarpi, are incomplete and size dimorphism is present in most elements. 3 premaxillae: S42357, S42827, S42857; 5 mandibles: S40955, S42473, S42660, S42672, S42847; 9 quadrates: S42403, S42404, S42503, S42575, S42666, S42667, S42692, S42840, S42846; 3 scapulae: S40951, S42251, S42668; 9 coracoids: S40953, S42673, S42674, S42675, S42694, S42834, S42844, S42848, S42871; 17 humeri: S40946, S40952, S42293, S42301, S42402, S42407, S42408, S42474, S42664, S42665, S42676, S42786, S42789, S42839, S42859, S42865, S42872; 5 ulnae: S42303, S42693, S42790, S42849, S42858; 1 radius S42576; 9 carpometacarpi: S40947, S40954, S40981, S42472, S42695, S42816; S42843, S42845, S42864; 2 wing phalanges: S42670, S42835; 6 femora: S42294, S42406, S42411, S42659, S42669, S42870; 34 tibiotarsi: S40106, S40107, S40108, S40444, S42224, S42225, S42247, S42248, S42291，S42295, S42299, S42300, S42302, S42339, 
S42401, S42476, S42477, S42478, S42479, S42573, S42661，S42662，S42691，S42696, S42699, S42787, S42837, S42838, S42861, S42863, S42866, S42867, S42868, S42869; 12 tarsometatarsi: S40442, S40499, S42405, S42489, S42495, S42503, S42555, S42690, S42791, S42814, S42836, S42862.

\section{New species 2 - magn. Gallirallus philippensis goodsoni (Fig. 11K)}

MATERIAL. 1 quadrate: S.40957; 2 femora: S.42658, S.42785.

REMARKS. Rails are the most abundant taxon after anatids in the St Bathans Fauna. We have referred 118 bones to at least two taxa based on morphology and size variation. Only one major element, a femur (MNZ S42870), is complete, making it difficult to define size ranges or to associate different elements to a taxon. In the following discussion we use Gallirallus for the barred wing rails following Olson (1973) and Dickinson (2003).

The leg bones, especially tibiotarsi, indicate that the most common species (new sp. 1) was about the size of the slaty-breasted rail Gallirallus striatus (Linnaeus, 1766) e.g. MNZ 25709 or the banded rail Gallirallus philippensis assimilis (G. R. Gray, 1843) with distal tibiotarsus widths having a non-overlapping bimodal size distribution over the ranges 4.4-5.4 and 5.4-6.2 mm. By way of comparison, the modern G. p. assimilis from New Zealand, which does not have a noticeable bimodal size distribution in our specimens, although it is sexually dimorphic in size (Livezey 2003), ranges from $5.2 \mathrm{~mm}$ (MNZ 22107) to $6.3 \mathrm{~mm}$ (MNZ 23802).

For all other elements, one or two size classes predominate as for tibiotarsi and so are referred to the same taxon. There are relatively few femora and tarsometatarsi, but most are of expected size, given the distal widths of tibiotarsi. The complete femur (MNZ S42870) is of similar length to that of $G$. striatus but is slightly more robust at each end: $\mathrm{L}=46.0 \mathrm{~mm}, \mathrm{PW}=8.0 \mathrm{~mm}, \mathrm{SW}=3.0 \mathrm{~mm}, \mathrm{DW}=7.6 \mathrm{~mm}$ (Fig. 11E).

All pectoral girdle elements are smaller than predicted, given the common fossil taxon had legs the size of $G$. striatus or G. p. assimilis. The partial rail humeri include seven similar in size to that of the Chatham Island rail Cabalus modestus (Hutton, 1872), e.g. MNZ S30115, or Porzana species such as the spotless crake Porzana tabuensis (J. F. Gmelin, 1789), e.g. MNZ 23823, while 10 are slightly larger specimens, about the size of humeri of the Auckland Island rail Dryolimnas muelleri (Rothschild, 1893) e.g. MNZ 25556. The widths of the proximal humeri from the ventral end of the capital groove to the dorsal tubercle range from $4.0 \mathrm{~mm}$ (MNZ S42665, S42786) to $4.5 \mathrm{~mm}$ (MNZ S42664, S42789). All 16 fossil outer wing elements are also small. For example, carpometacarpi range in total length from $12.2 \mathrm{~mm}$ (MNZ S42816) to $15.3 \mathrm{~mm}$ (MNZ S40981) with proximal widths of $3.2 \mathrm{~mm}$ (MNZ S42816) to $3.9 \mathrm{~mm}$ (MNZ S40947).

In shape, the proximal humeri resemble those of the flightless Cabalus far more than those of any volant rails, small or large, such as G. philippensis, G. striatus, the blacktailed native-hen Gallinula ventralis Gould, 1837 (e.g. MNZ 22100, 22101), or the Virginia rail Rallus limicola Vieillot, 1819 (e.g. MNZ 27336). The fossils feature a shallow nonpneumatic (rather than excavated) ventral pneumotricipital fossa, a short bicipital crest (rather than one extending further distally down the humeral shaft), a low rounded (rather than more protuberant) humeral head and a narrow shaft that is ridged caudally, which are all features indicative of a flightless species (Livezey 2003: table 63, features A, B, $\mathrm{E}$ and $\mathrm{M} / \mathrm{N}$, respectively). To this we add the feature of the deltoid crest being rotated farther over the cranial surface, so accentuating the prominence of the dorsal tubercle. Therefore, new sp. 1 was flightless and had very reduced wings and a dimorphic size range. Sexual size dimorphism is especially prevalent in flightless rails (Livezey 2003: 94, 349).

The second fossil species (new sp. 2) is slightly larger than new sp. 1 and similar in size to the tropical banded rail G. philippensis goodsoni (Mathews, 1910-1911) e.g. MNZ 25269. The quadrate (MNZ S40957) is notably stouter than the other fossil quadrates. It has a particularly short 'shaft' leading to the process containing the quadratojugal socket, when compared with that of G. philippensis, the weka G. australis (Sparrman, 1786), Porzana and Gallinula ventralis; the otic process is more stocky with a shallower incisura intercapitularis than that found in G. philippensis, G. australis and Porzana and is even stouter than the fairly stout process of $G$. ventralis. This larger quadrate probably indicates some generic diversity in the fossil rail fauna. The femora (MNZ S42658: $\mathrm{PW}=8.5 \mathrm{~mm}, \mathrm{SW}=4.0$; $\mathrm{MNZ}$ S42785: $\mathrm{PW}=8.0 \mathrm{~mm}$ ) are flat ventrally at the level of the trochanter and so lack the narrow ridge on the shaft laterad of a deep medially open sulcus as in new sp. 1 and they have a more rounded lateral facies at the distal end of the trochanter.

The fragmentary nature of the rail fossils precludes much discussion on phylogenetic relationships at this stage. All post-cranial bones are most similar to Gallirallus species, with none having any affinity to gallinules. However, some comments on the relationships can be made based on the skull fragments, which are presumed to belong to new sp. 1. The premaxilla tips (MNZ S42357, S42827, S42857) and mandible tips (MNZ S42473, S42672) are noticeably deeper and a little larger, but most closely resemble those of $G$. philippensis and resemble to a lesser extent, those of G. australis, Dryolimnas muelleri, Porzana and G. striatus. They are considerably more truncated than the long premaxilla and mandible tips of Cabalus modestus and Rallus limicola and not as broad as those of Gallinula. The crista tomalis of the premaxilla is sharp, as in Gallirallus, Rallus, Cabalus, Dryolimnas, Porzana and Gallinula, not flat and broad occlusally, as in Hawkins' rail Diaphorapteryx hawkinsi (Forbes, 1892a) and the extinct Fiji rail Vitirallus watlingi Worthy, 2004 (Worthy 2004b) e.g. MNZ S37543. The bill fragments and the three partial posterior mandibles (MNZ S40955, S42660 and S42847) suggest that new sp. 1 had a stouter bill than that found in modern similar-sized (based on legs) Gallirallus species, e.g. G. striatus or G. p. assimilis.

The quadrates referred to new sp. 1 have a very prominent pterygoid articulation (MNZ S42403, S42667), an elongate mandibular articular surface (MNZ S40503, S42403, S42667 and S42846) and a relatively slender and flattened otic process (MNZ S42403, S42575, S42666, S42667, S42692, S42840 and S42846) with a deep incisura intercapitularis (sensu Howard 1929: 315). The prominent pterygoid articulation is similar to that found in Porzana and Gallirallus but is unlike that found in Gallinula. The otic processes of the fossils are most like those of Gallirallus - the processes 

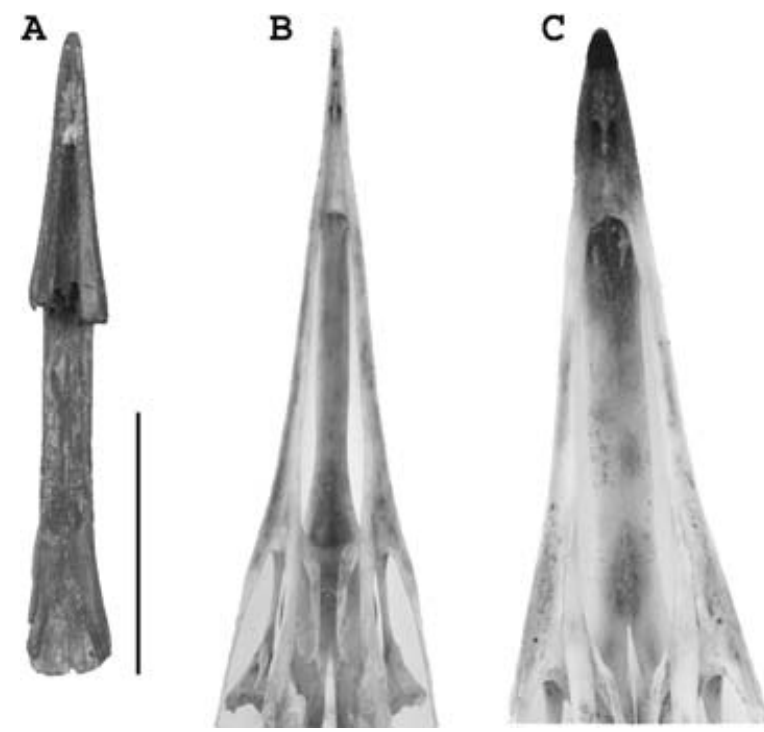

Figure 12 Gull (Laridae) premaxilla in occlusal view. A, ?Laridae, gen. et sp. indet. fossil MNZ S42681; B; Larus bulleri MNZ 25098, Recent; C, Larus dominicanus MNZ 24270, Recent. Scale bar $=20 \mathrm{~mm}$.

are not quite as elongate as those found in Porzana or as stout as those of Gallinula. The elongate mandibular articular surface of the fossils is similar to that found in G. australis and close in shape to that of Porzana and G. philippensis but is relatively unlike the short articular surface found in Gallinula. Thus, among the compared taxa, the fossils have most similarity to those of Gallirallus.

All of the fossils represent fairly small taxa, none being larger than $G$. philippensis. Thus the Manuherikia rail fauna appears to have lacked larger species, of which there was a considerable diversity in the Recent fauna of New Zealand, e.g. G. australis, Diaphorapteryx, Gallinula, Porphyrio and Fulica species (Holdaway et al. 2001).

\section{Order CHARADRIIFORMES Huxley, 1867 Family ?LARIDAE Rafinesque, 1815}

\section{Genus and species indet. (Fig. 12A)}

MATERIAL. MNZ S42736, premaxilla, HH1a; MNZ S42681, premaxilla, HH1a (Fig. 12A); MNZ S41058, proximal end R scapula, Croc Site L1.

MEASUREMENTS. MNZ S42736, total length $=47.7 \mathrm{~mm}$, symphyseal length $=19.0 \mathrm{~mm}$ (tip is worn); MNZ S42681, total length $=\sim 50.0 \mathrm{~mm}$, symphyseal length $=21.7 \mathrm{~mm}$.

REMARKS. Both premaxillae MNZ S42736 and MNZ S42681 are referred to Laridae based on their overall similarity to gulls, more so than to any other taxon. They feature a rostrum maxillare with the following features: it is shorter than the os nasale; it has a downcurved tip; and it has flattened sides resulting in an acute rather than broadly rounded dorsal surface. The premaxillae are thus similar to galliralline rails, which also have a shorter maxillary rostrum than the supporting os nasale, but have a broadly dorsallyrounded maxillary rostrum and generally not such a decurved tip. Terns e.g. Sterna bergii, which is the most similar tern to the fossil, have a longer maxillary rostrum than the os na-

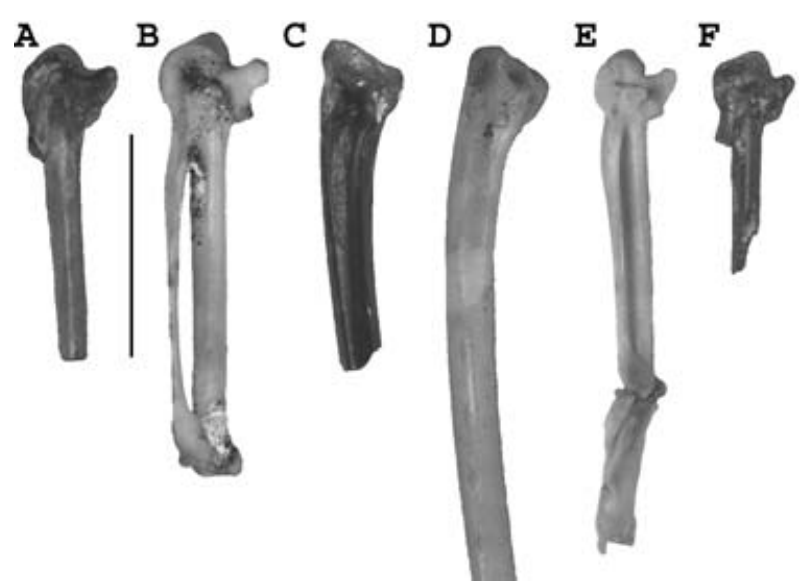

Figure 13 Charadriiform bones. A, fossil pL cmc MNZ S42434; B, Charadrius bicinctus MNZ 24688, L cmc, Recent; C, fossil pL ulna MNZ S42807; D, C. bicinctus MNZ 24688, L ulna, Recent,; E, Calidris ruficollis MNZ 23292, L cmc, Recent; F, fossil pL cmc MNZ S42415. Scale bar $=10 \mathrm{~mm}$.

sale. The fossils indicate a species slightly smaller than Larus dominicanus Lichtenstein, 1823 (e.g. MNZ 24270: Fig. 12C) but they feature a straighter and more elongate bill tip that is very similar in shape, although larger, to that of $L$. bulleri Hutton, 1871 (e.g. MNZ 25098: Fig. 12B). Unlike the bill of $L$. dominicanus, but like that of L. bulleri, on the fossil premaxillae the crista tomalis is thickened along its length (Fig. 12A). This feature is generally lacking in gulls, but is a feature of some birds that manipulate prey in their bills, e.g. Phalacrocorax species, so perhaps these gulls were fish eaters. Larus bulleri preys on a variety of food, including insects captured aerially (Higgins \& Davies 1996).

The scapula, MNZ S41050, has the rather featureless shape of charadriiforms and is of appropriate size to belong to the bird that the above premaxillae are derived from.

\section{Family, genus and species undetermined (Fig. 13)}

MATERIAL. Three bones from Croc Site Layer 1 are from a very small charadriiform the size of a red-necked stint $C$ alidris ruficollis (Pallas, 1776) e.g. MNZ 23292: MNZ S42416, a fragment of a pR hum; MNZ S42415, a pL cmc (Fig. 13F); MNZ S42435, a pL cmc.

Eight mainly fragmentary bones are from a charadriiform that differs little from the New Zealand banded dotterel Charadrius bicinctus Jardine \& Selby, 1827, e.g. MNZ 23889 or 24688: MNZ S42413, dR ulna, Croc Site L1; MNZ S42807, pL ulna, HH1a (Fig. 13C); MNZ S42434, pL cmc, Croc Site L1 (Fig. 13A); MNZ S42877, pL cmc, HH2c; MNZ S42414, pR scap, Croc Site L1; MNZ S42850, L scap, HH1a; MNZ S42860, ant stern, HH1a; MNZ S42475, R cor, Croc Site L1.

REMARKS. These few bones, assigned on the basis of overall similarity, are sufficient to indicate the presence of at least two small waders in the fossil fauna. The genus Calidris includes the smallest waders in the world and the fossil is of similar size to $C$. ruficollis, one of the smallest species in the genus. More diagnostic material is required to determine whether the genera Calidris and Charadrius were indeed a part of the fauna. 
A

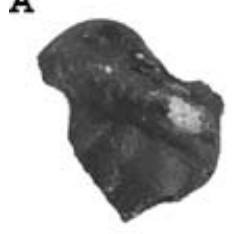

B

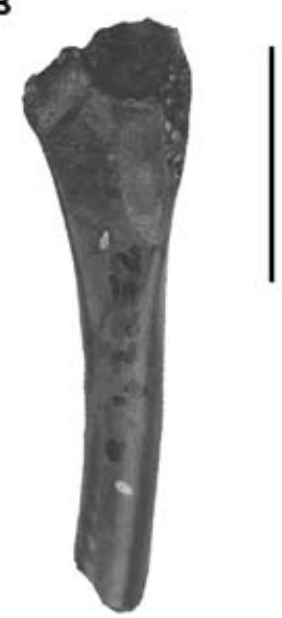

C

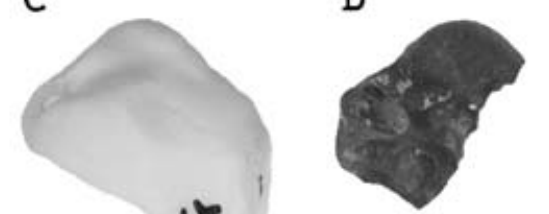

E

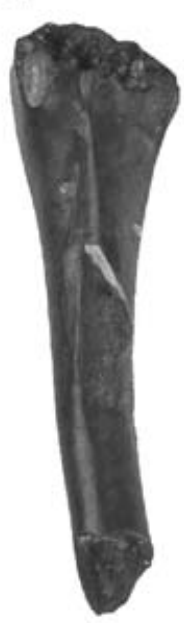

F

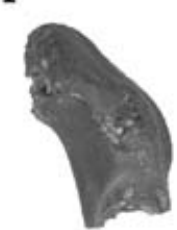

G
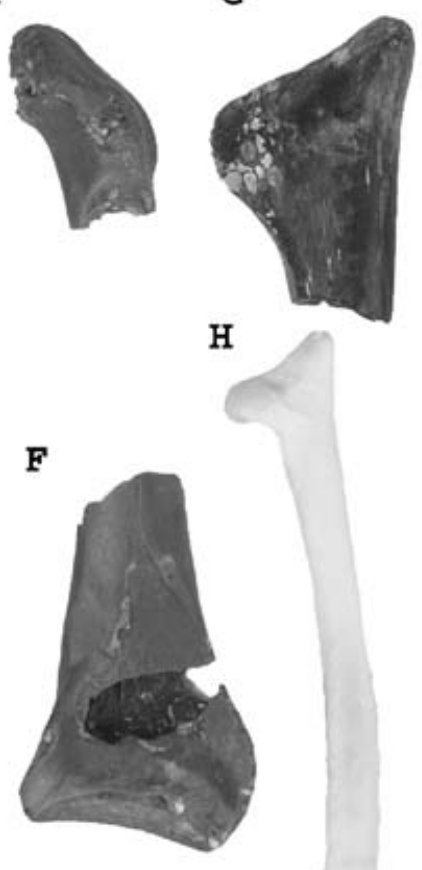

I

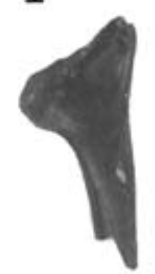

$\mathrm{K}$

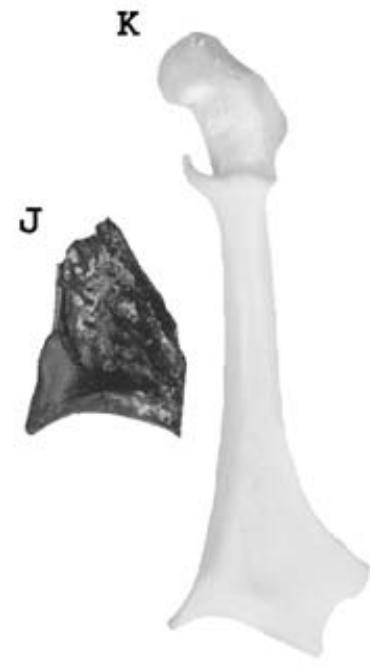

Figure 14 Representative fossil parrot bones, Psittacidae gen. et sp. indet., from St Bathans compared to those of Recent Cyanoramphus unicolor MNZ 15289 (C, H, K). A, D, small species, MNZ S42854 pR hum; B, E, small species, MNZ S42252 shaft L hum; C, MNZ 15289 L humerus; F, medium-sized species, MNZ S42550 humeral and sternal parts R cor; G, large species, MNZ S42246 L scap; H, MNZ 15289 L scap; I, small species, MNZ S42833 L scap; J, small species, sternal end R cor MNZ S42855; K, MNZ 15289 R cor. Scale bar = 10 mm.

\section{Order COLUMBIFORMES Latham, 1790 Family COLUMBIDAE Illiger, 1811}

\section{Genus and species indet. (Fig. 10F)}

MATERIAL. MNZ S42430, dR ulna, HH1a.

MEASUREMENTS. Dorsoventral SW $=3.04 \mathrm{~mm}$, length of cond. dorsalis ulnaris $=5.26 \mathrm{~mm}$, width of cond. dorsalis ulnaris $=5.60 \mathrm{~mm}$.

REMARKS. MNZ S42430 is referred to Columbidae because of the following features: the dorsal condyle is as long as it is wide and distinctly concave across the base of its caudal face, in distal view the caudal face of the dorsal condyle and the dorsal facies form a right angle and the shaft has prominent papillae remigales caudales. It is of similar size to Ptilinopus magnificus (MNZ 27278). Of the taxa in the Australasiansouthwest Pacific region, it is thus bigger than all other Ptilinopus species, all Phaps and Gallicolumba species and it is similar in size to some Macropygia, Columba and smaller Ducula species. The carpal tuberculum is short and robust, as in the brown cuckoo-dove Macropygia amboinensis phasianella (Temminck, 1821) (MNZ 27230: Fig. 10E) and Ptilinopus spp., rather than it being longer, as in the feral pigeon Columba livia Gmelin, 1789 (MNZ 14973). The spacing of the caudal remigal papillae is most similar to Ducula (e.g. the Pacific pigeon D. pacifica (Gmelin, 1789): MNZ 27340), albeit from a smaller bird, indicating a more elongate and straighter ulna than in M. a. phasianella or in the Wompoo fruit dove Ptilinopus magnificus (Temminck, 1821), which otherwise are of comparable size.

A distal ulna is insufficiently diagnostic to assign to any genus within columbids, so this fossil indicates only that a medium-sized pigeon was present in the fauna.

\section{Order PSITTACIFORMES Wagler 1827 Family PSITTACIDAE Rafinesque, 1815}

\section{Genus and species indet. (Figs 14A, B, D-F, G, I, J)}

MATERIAL. Sixteen fossils represent a parrot about the size of the crimson rosella Platycercus elegans (Gmelin, 1788), e.g. MNZ 26998, or the Antipodes parakeet Cyanoramphus unicolor (Lear, 1831), e.g. MNZ 15289 (Figs 14C, H, K).

A shaft and part proximal L humerus (MNZ S42252) from Croc Site L1 (Figs 14B, E) is most similar to parrots in that the insertion point for the principle part of the tendon of M. supracoracoideus is a recessed pit, not a 'tuberculum dorsale', that is flush with the dorsal surface of the deltoid crest, and in that there is a tuberosity on the margo caudalis just distad of the base of the said pit. The base of the deltoid crest is thick and the cranial surface adjacent to the proximal end of the deltoid crest has a shallow fossa typical of parrots. The fossil differs from Platycercus, Cyanoramphus and Nestor in that the bicipital crest joins to the shaft at a shallow angle, not at near right angles. It is similar to Nestor 
and Cyanoramphus in the presence of a distinct ridge aligned slightly obliquely on the shaft caudally. A part proximal R humerus (MNZ S42854) from HH1a (Figs 14A, D) preserves part of the head, the complete bicipital crest and the ventral tubercle and is similar to Cyanoramphus.

Two sternal ends of R coracoids from HH1a, MNZ S42855 (with a width across sternal facet of $7.0 \mathrm{~mm}$ : Fig. 14J) and MNZ S42663, differ markedly from all compared species in that the medial angle is less acute and has a large flange extending above it.

Other bones provisionally referred to this taxon are: MNZ S42833, L scap, HH1a, width across articular surfaces $=6.2 \mathrm{~mm}$ (Fig. 14I); MNZ S42615, dL ulna, HH1a; MNZ S42671, dL ulna, HH1a; MNZ S42832, dL ulna, HH1a; MNZ S42409, pL cmc, Croc Site L1, proximal width $5.1 \mathrm{~mm}$; MNZ S42480, R cmc, Croc Site L1, length 24.8 mm, approximate proximal width $5.1 \mathrm{~mm}$; MNZ S40447, last thoracic vertebra, HH1a (this fossil has a deeper lateral fossa in the corpus vertebrae than in the compared platycercines); MNZ $\mathrm{S} 42723$, pR fem, HH1a, proximal width $=5.46 \mathrm{~mm}$, proximal depth $=3.0 \mathrm{~mm}$; MNZ S42784, dR tib, HH1a, distal width $=$ c. $5.8 \mathrm{~mm}$, width at tendinal bridge $=4.7 \mathrm{~mm}$; MNZ S42853, dL tib, HH1a, width at tendinal bridge $=4.6 \mathrm{~mm}$; MNZ S42614, trochlea metatarsi III of R tmt, HH1a; MNZ S42856, trochlea III and part of distal end including distal foramen of $\mathrm{L} \mathrm{tmt,} \mathrm{HH1a.}$

Two specimens represent a parrot slightly smaller than the North Island kaka Nestor meridionalis septentrionalis Lorenz, 1896, e.g. MNZ 26892. The dR femur MNZ S42400, Croc Site L1, distal width $=9.5 \mathrm{~mm}$, is referred to Psittaciformes on general similarity to platycercine femora. It differs in having a lower ridge bounding the popliteal fossa medially, but is similar to Cyanoramphus in having a shallow fossa above the trochlea fibularis and a large impressio ansae $m$. iliofibularis that is separated from the fibula trochlea. In Nestor, the fossa above the fibular trochlea is very deep and the impressio ansae $m$. iliofibularis abuts the fibular trochlea. The unconnected humeral and sternal ends of a $\mathrm{R}$ coracoid, MNZ S42550 (Fig. 14F), HH1a, apparently broken during excavation, do not articulate but have similar preservation and derive from the same small lot of sediment concentrate and so are assumed to be the fragmented parts of a single bone. The sternal end differs markedly from all compared Recent species in that the medial angle is less acute and has a large flange extending above it and so is similar to the smaller fossil parrot types. Proximally, the acrocoracoid has large pneumatic foramina, as in Cyanoramphus but unlike Nestor. One specimen (MNZ S42246, pL scapula, Croc Site L1: Fig. 14G) represents an even larger species, similar in size to the kea Nestor notabilis Gould, 1856, e.g. MNZ 22028.

REMARKS. The available material indicates that at least three species of parrots were present in the St Bathans Fauna. The form of the coracoids (S42550, S42663 and S42855), is unlike that of any parrots examined so far and since all are similar, this indicates that the small and medium-sized taxa may be congeneric. The fossil coracoids have a relatively deep impressio $m$. sternocoracoidei, which form is approached in the platycercine taxa examined, but is unlike the very shallow impression found in Cacatuidae. In contrast, the coracoid flange above the medial angle is similar to that in Cacatua galerita (Latham, 1790) but this feature was not seen in any platycercine taxon. The form of the scapulae also indicates
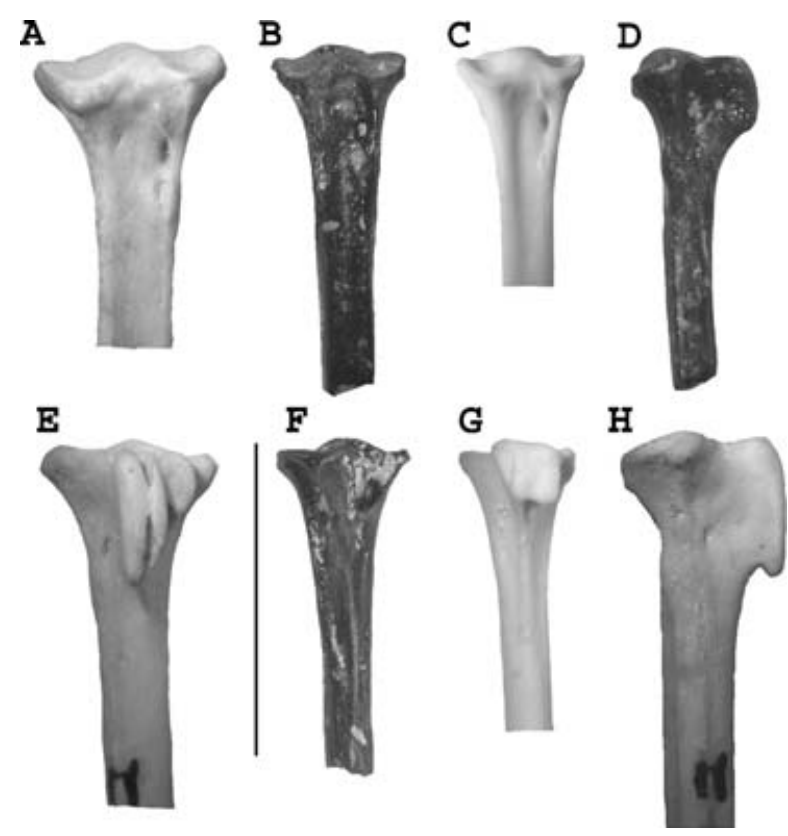

Figure 15 Tarsometatarsi of owlet nightjars Aegotheles sp. A-D in dorsal view, E-H in plantar view. A, E, H, A. novaezelandiae, MNZ S1002, Recent; B, D, F, Aegotheles sp., fossil, MNZ S42800; C, G, Aegotheles cristatus MNZ 26990, Recent. Scale bar $=10 \mathrm{~mm}$.

that the fossil taxa differ from Cacatuidae, whose members have scapulae with pneumatic foramina in the acromion. Platycercine taxa have scapulae that lack pneumatic fossae and are thus like the fossils, however until more complete material and wider comparisons have been made, it would be premature to accept any relationship between this group and the fossils.

\section{Order AEGOTHELIFORMES Simonetta, 1967 Family AEGOTHELIDAE Bonaparte, 1853}

The family Aegothelidae has usually been listed in Caprimulgiformes but much recent work, reviewed by Sangster (2005), supports the sister-group relationship of Aegothelidae (owlet-nightjars) and Apodiformes (swifts and hummingbirds) to the exclusion of other members of Caprimulgiformes, first proposed by Mayr (2002a, 2003). Sangster (2005) used Daedalornithes as the new name for this clade, but it requires elevation of Aegothelidae to ordinal status as first recognised by Simonetta (1967).

\section{Genus AEGOTHELES Vigors \& Horsfield, 1827}

\section{Aegotheles sp. indet. (Figs 15B, D, F)}

MATERIAL. MNZ S42800, proximal right tarsometatarsus lacking lateral side of hypotarsus, HH1a.

MEASUREMENTS. Proximal width $=4.3 \mathrm{~mm}$; proximal depth $=4.1 \mathrm{~mm}$; least shaft width $=1.6 \mathrm{~mm}$; preserved length $=11 \mathrm{~mm}$, which is likely to be less than half of the total length.

REMARKS. This fossil is identified as Aegotheles because of the following combination of features: lateral and medial cotyla overhang shaft to equal extent; hypotarsus is composed 
of two main ridges separated by an enclosed canal; there is a deep broad fossa parahypotarsalis medialis within which the medial vascular foramen opens level with the distal end of the hypotarsus as a small hole; the intercotylar eminence is low and rounded, only slightly elevated above the cotylar margins; anteriorly, the extensor sulcus is shallow with a large medial proximal vascular foramen sited just proximad of a large, ovate, elevated tuberositas $m$. tib. cranialis that abuts the medial facies; the shaft (although incompletely preserved) is apparently gracile and elongate, with the anterior facies flat and the posterior facies convex.

All members of Apodiformes have very short and gracile tarsometatarsi that differ markedly from those of $\mathrm{Ae}$ gotheles.

Members of Caprimulgiforms, to which Aegotheles have been generally allied, differ as follows. Podargidae, e.g. Podargus strigoides (Latham, 1802) e.g. MNZ 27001, differ by their much larger size, short stout tarsometatarsi with two small centrally placed proximal vascular foramina in the extensor sulcus and by having a hypotarsal structure of two principle canals and three ridges, of which the medial ridge is shorter than the middle one.

The Caprimulgidae, e.g. Eurostopodus mystacalis (Temminck, 1826) e.g. MNZ 27369 and 27370, and E. argus (Hartert, 1892) e.g. MNZ 27371, also differ greatly from Aegotheles in tarsometatarsal structure. They have short stout tarsometatarsi with a single centrally placed opening in the extensor sulcus from which lateral and medial proximal vascular foramina open interiorly, the tuberositas m. tib. cranialis is centrally placed in the extensor sulcus, the shaft is concave posteriorly with a prominent medial crest, but the hypotarsus has a single canal as in aegothelids.

The fossil is slightly larger than the tarsometatarsus of Aegotheles cristatus (Shaw, 1790) e.g. MNZ 26990 (Figs 15C, G), 22103, and is smaller than those of $A$. novaezealandiae (Scarlett, 1968) (Figs 15A, E, H) or A. savesi Layard \& Layard, 1881 (specimens from Pindai Cave, Testpit 4, spits 22-24, 21 July 2003, MNZ unreg). It further differs from A. cristatus and is similar to A. novaezealandiae and $A$. savesi in that the medial hypotarsal ridge is higher or extends more plantarly than the rest of the hypotarsus (A. cristatus has a flat plantar surface to the hypotarsus). The medial hypotarsal ridge is elongate, at least twice as long as the medial ridge (as in A. novaezealandiae, but unlike A. cristatus where they are of equal length and $A$. savesi where the medial is only a little longer than the lateral ridge). The fossil differs from A. savesi in that the medial parahypotarsal fossa is smaller, being of similar extent to that in A. novaezealandiae.

\section{Family APODIDAE Olphe-Gaillard, 1887 Genus COLLOCALIA Gray, 1840}

\section{Collocalia sp. indet. (Fig. 16A)}

MATERIAL. MNZ S42799, R ulna, HH1a.

MEASUREMENTS. Total length $=11.2 \mathrm{~mm} ; \mathrm{PW}=2.9 \mathrm{~mm}$; $\mathrm{SW}=1.4 \mathrm{~mm}$; DW $=2.4 \mathrm{~mm}$.

REMARKS. This ulna is from an apodid swift and is very much smaller than that from either of the chaeturines: Hirundapus caudacutus (Latham, 1802) (e.g. MNZ 21833) or H. cochinchinensis (Oustalet, 1878) (e.g. MNZ 25710)
A

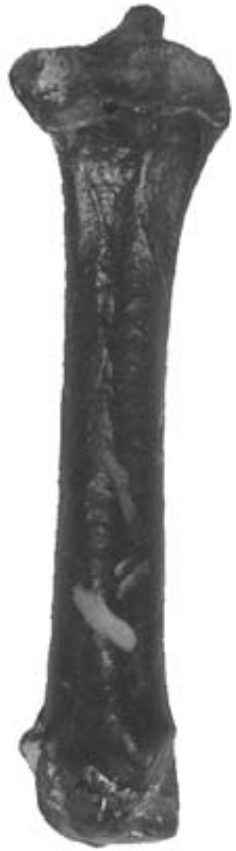

B

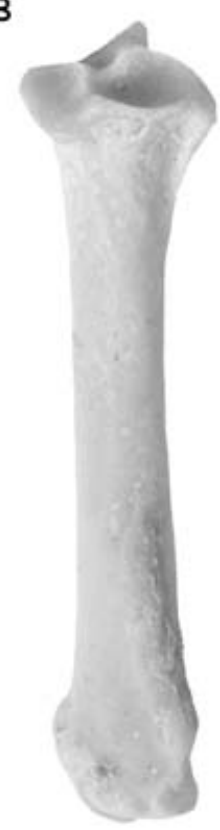

Figure 16 Right ulnae of swiftlets Collocalia sp. A, Collocalia sp. fossil, MNZ 42799; B, C. spodiopygia, MNZ 26799, Recent. Scale bar $=5 \mathrm{~mm}$.

and much smaller than the apodine swift Apus affinis (Gray, 1830) (e.g. MNZ 24340). It is similar in size and form to collocaline swiftlets Collocalia species (of which Aerodromus is here considered a synonym, following Boles (2001) and Steadman (2002)), especially in the short acromion (more anteriorly directed and longer in Apus), presence of a shallow fossa on the lateral facies below the cond. ventralis (lacking in Apus) and in the shape of the tuber. lig. collateralis ventralis, which in the fossil is widest medially and narrows dorsally (in Apus it is broad over the medial-dorsal extent). The fossil is slightly longer and more stout than C. spodiopygia (Peale, 1848) (e.g. MNZ 26799, Fig. 16B: $\mathrm{TL}=10.6 \mathrm{~mm}$; THW colln, Fiji 5 June 1997, TL $=10.9 \mathrm{~mm})$ and C. esculenta (Linnaeus, 1758) (MNZ 23002, TL = $10.1 \mathrm{~mm}$; MNZ 22993, TL $=10.4 \mathrm{~mm}$; MNZ 22991, TL $=$ $10.3 \mathrm{~mm}$ ). It is substantially smaller than the ulnae of the mountain swiftlet Collocalia hirundinacea Stresemann, 1914, e.g. AU9481, V347 TL $=13.6 \mathrm{~mm}$, AU9481, V348 $\mathrm{TL}=13.7 \mathrm{~mm}$ and $\mathrm{AU} 9481, \mathrm{~V} 349 \mathrm{TL}=13.3 \mathrm{~mm}$, from Papua New Guinea. The fossil differs in form, with the ventral condyle being relatively more elongate dorsoventrally than in the modern taxa compared. The channel separating the dorsal cotyla from the olecranon (which opens into the dorso-caudal part of the ventral cotyla) is also relatively wider and deeper than in the modern taxa. In the fossil, the brachial impression is relatively shallow, as in C. esculenta, and unlike the deeper condition of $C$. spodiopygia.

Recently, Collocalia buday Boles, 2001 was described from the Oligo-Miocene of Australia. It is a large species, larger than all compared Collocalia species (Boles 2001) so, while comparative elements are not yet available, the New Zealand fossil derives from a smaller species. Boles (2001) presented data indicating that $C$. maxima (Hume, 1878), $C$. brevirostris (Horsfield, 1840) and C. inexpectata (Hume, 1873) are a little larger than $C$. spodiopygia and thus are 


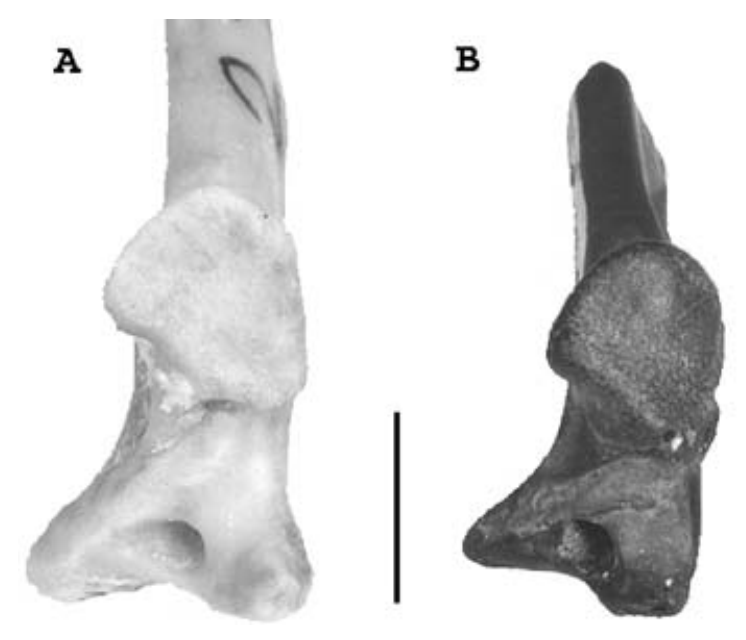

Figure 17 Passerine right scapulae. A, Strepera graculina MNZ 27326, Recent; B, fossil MNZ S41061. Scale bar $=5 \mathrm{~mm}$.

likely to have similar ulnae length as the fossil described here. Until wider comparisons are possible, all that can be determined of this fossil is that a collocaline swiftlet was part of the St Bathans Fauna.

\section{Order PASSERIFORMES Linnaeus, 1758 Family CRACTICIDAE Amadon, 1943}

\section{Genus and species indet. (Fig. 17B)}

MATERIAL. MNZ S41061, R scapula, Croc Site L1.

REMARKS. This well preserved passerine scapula is referred to the Cracticidae because of the combination of the following characters: (1) the acromion is short and robust; (2) the angle of a line linking the acromion with the lateral side of the coracoid tubercle and the lateral side of the humeral articular facet is about $90^{\circ}$; (3) there is a large pneumatic foramen in the base of the coracoid tubercle between it and the acromion.

The scapula in species within Callaeidae (New Zealand wattlebirds), Corcoracidae (Australian mudnesters) and Corvidae (crows and jays), which include relatively large taxa, such as the fossil represents, all lack such a pneumatic foramen. An exception is the white-winged chough Corcorax melanorhamphos (Vieillot, 1817), which in some individuals has a small foramen, e.g. MNZ 27034, but in others does not e.g. MNZ 27035. However, the acromion of the choughs extends well dorsad of the coracoid tubercle, unlike in the fossil.

Within the Australasian fauna, some taxa are known to have a similarly placed fossa. These include the meliphagids, e.g. pied honeyeater Certhionyx variegatus Lesson, 1830 e.g. MNZ 26996, New Caledonian friarbird Philemon diemenensis (Lesson, 1831) e.g. MNZ 22996 and the red wattlebird Anthochaera carunculata (Shaw, 1790) (Walter Boles, pers. comm., 28 June 2004), but not the New Zealand Prosthemadera, Anthornis and Notiomystis. The pachycephalids e.g. rufous whistler Pachycephala rufiventris (Latham, 1802) e.g. MNZ 26997, grey shrike-thrush Colluricincla harmonica (Latham, 1802) (Walter Boles, pers. comm., 28 June 2004) and the New Zealand piopio Turnagra spp, Turnagridae e.g. MNZ 1390 (these are allied to pachycephalids by Schodde \& Mason 1999: 432) also have a large fossa. Lastly, some monarchines have a similar fossa e.g. southern shrikebill Clytorhynchus pachycephaloides Elliot, 1870 and magpie-lark Grallina cyanoleuca (Latham, 1802) e.g. MNZ 27036. All of these taxa are very much smaller birds in groups that are not known to have any members as large as that represented by the fossil. Also, in all these taxa, the acromion is elongate and flattened unlike the fossil, except for Philemon which differs markedly in having a short acromion but which is still flattened lateromedially and has a very large coracoid tubercle that is about twice the size of the acromion.

There are only four Australasian families with relatively large taxa that were found to have a pneumatic foramen in the scapula. The lyrebirds, Menuridae (Menura novaehollandiae Latham, 1802 e.g. MNZ 27159), have variation in the size of the pneumatic foramen both within and between individuals (pers. obs; Walter Boles, pers. comm., 28 June 2004). However, the shape of the lyrebird's scapula differs markedly from cracticids, with the coracoid tubercle extending markedly above the lateral facies and the acromion being relatively longer and flattened.

The bowerbirds Ptilinorhynchidae include no taxa as large as the fossil, but several species were found to have large pneumatic foramina in the scapula e.g. the satin bowerbird Ptilonorhynchus violaceus (Vieillot, 1816) e.g. MNZ 16048, green catbird Ailuroedus crassirostris (Paykull, 1815) and fawn-breasted bowerbird Chlamydera cerviniventris Gould, 1850 (Walter Boles, pers. comm., 28 June 2004). The scapula of Ptilonorhynchus violaceus differs in shape from cracticids, with the acromion being more produced dorsally such that a line linking the acromion, the tip of the coracoid tubercle and the lateral margin of the humeral articular facet forms a wide angle.

Birds of paradise (Paradisaeidae) have not been widely examined by us, but this is a highly tropical group whose centre of diversity is in the mountains of Papua New Guinea and for which there are only four species in tropical northern Australia (Schodde \& Mason 1999). However, the scapula of at least some species has a large pneumatic foramen e.g. trumpet manucode Manucodia keraudrenii (Lesson \& Garnot, 1826) and magnificent riflebird Ptiloris magnificus (Vieillot, 1819) (Walter Boles, pers. comm., 28 June 2004). The scapula of Manucodia is very different to cracticids and is shaped more like that of Corvus (which differ in lacking a pneumatic foramen), with the acromion positioned well dorsad of the coracoid tubercle so that the angle of the line linking the acromion with the lateral side of the coracoid tubercle and the lateral side of the humeral articular facet is about $120^{\circ}$. Moreover, the acromion of Manucodia is lateromedially flattened and the coracoid tubercle is relatively small.

The butcherbirds Cracticidae, which includes Australian magpies and currawongs, is the only other family whose members have a large pneumatic foramen in the scapula. Cracticids have recently been included as a subfamily in Artamidae by Schodde \& Mason (1999), but here we follow Dickinson (2003). The scapula of the white-breasted woodswallow, Artamus leucorynchus melaleucus Wagler, 1827 e.g. MNZ 22995 and the dusky woodswallow, A. cyanopterus (Latham, 1802) e.g. MNZ 27033, have a short and not flattened acromion as in cracticids, but they lack a pneumatic foramen. 


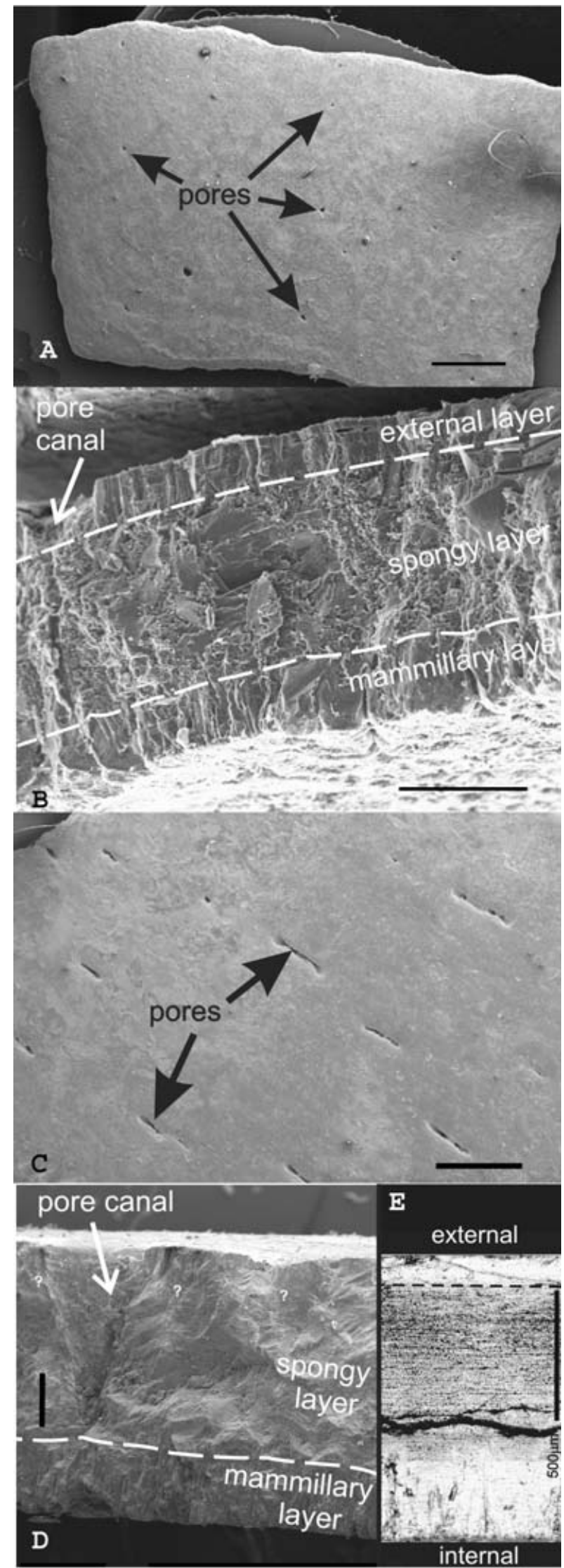

Figure 18 Avian eggshell from the St Bathans Fauna. A, Scanning electron micrograph (SEM) showing the general appearance of the thin eggshell; B, SEM of a cross-section of the thin (?anatid) eggshell
The butcherbirds Cracticus species e.g. C. torquatus (Latham, 1802) e.g. MNZ 27037, are notably smaller than other cracticids, but they have similar-shaped scapulae to those of species in other genera in the family. The species in Gymnorhina and Strepera have scapulae of similar size to the fossil, which measures $7.3 \mathrm{~mm}$ from the acromion to the ventral side of the humeral articular facet. In Gymnorhina tibicen (Latham, 1802) e.g. MNZ 16060, 12256, $13695,11404,23534$ and 24235, the acromion is a little more hooked dorsally than in Strepera graculina (Shaw, 1790) e.g. MNZ 27326 and 27030, or in the fossil. In both Gymnorhina and Strepera, the coracoid tubercle varies considerably in shape, as does the size of the pneumatic fossa, but in all specimens examined it protrudes above the lateral facies. In the fossil it does not.

This fossil strongly suggests that a cracticid of similar size to an Australian magpie or currawong was present in the fauna.

\section{Passerine family, genus, species indet.}

MATERIAL. Ten bones are referred to passerines, family and species indeterminate, as follows: MNZ S42250, Croc Site L1, dL tmt; MNZ S42433, Croc Site L1, pL tmt; MNZ S42535, Croc Site L1, pR cmc; MNZ S42815, Croc Site L1, dR tmt; MNZ S40448, HH1a, dR tmt; MNZ S40956, HH1a, pL cmc; MNZ S42340, HH1a, dR tmt MNZ S42806, HH1a, dR tmt; MNZ S42842, HH1a, dL ulna; MNZ S42852, HH1a, mandible tip.

REMARKS. A minimum of two taxa based on size are represented. MNZ S42815 is the largest and represents a bird about the size of a tui Prosthemadera novaeseelandiae (Gmelin, 1788). The rest could derive from a single species and are from a bird about the size of a North Island saddleback Philesturnus rufusater (Lesson, 1828).

\section{Bird, family, genus, species indet.}

MATERIAL. Several bone fragments (40968, S42245 and S42812) are from moa-sized birds, as indicated by shaft cortex thicknesses of $c a$. 4.0, 3.5 and 4.0-4.5 mm, respectively. MNZ S42812 could be a fragment of a right tibiotarsus, preserving the fossa for the unfused astragalus in a juvenile bird. Whatever their true identity, these fragments reveal a bird larger than any considered above.

\section{Avian eggshell - family, genus, species indet.}

MATERIAL. Avian eggshell is common in the Bannockburn Formation, but most is thin $(<0.5 \mathrm{~mm})$ and presumed to be from the abundant anatids in the deposit. It has the usual neognath structure of three prominent layers: (1) a mammillary zone, $28 \%$ of thickness, (2) a squamatic zone (spongy layer), $54 \%$ of thickness and (3) an external zone, $18 \%$ of thickness (Figs 18A \& B).

showing three prominent layers; C, SEM of the external surface of the ?moa eggshell showing the characteristic elongate pores and smooth surface; D, SEM of a broken section of the ?moa eggshell showing the structure; $E$, thin section of the ?moa eggshell showing structure. Scale bars: A, $\mathbf{C}=1 \mathrm{~mm} ; \mathbf{B}, \mathbf{D}=100 \mu \mathrm{m}$. 
Table 8 Specimens of relatively thick eggshell that represent a bird the size of a small moa (Aves: Dinornithiformes).

\begin{tabular}{|c|c|c|c|}
\hline MNZ No. & Site name & & Thickness (mm) \\
\hline S40935 & Croc Site, layer 1 & 1 frag & 0.95 \\
\hline S 40936 & Vinegar Hill & 8 frags & $\begin{array}{r}1.00,1.10,0.90,0.90 \\
1.10,1.06,1.10,1.10\end{array}$ \\
\hline S 40937.1 & $\mathrm{H}_{1} \mathrm{~b}$ & 1 frag & 0.86 \\
\hline S 40937.2 & $\mathrm{HH}_{1} \mathrm{~b}$ & 1 frag & 1.68 \\
\hline S 40938.1-.3 & $\mathrm{H}_{1} \mathrm{~b}$ & 3 parts 1 frag & 1.10 \\
\hline S 40938.4 & $\mathrm{HH}_{1} \mathrm{~b}$ & $1 \mathrm{frag}$ & 0.90 \\
\hline S 40938.5-.7 & $\mathrm{H}_{1} \mathrm{~b}$ & 3 parts $1 \mathrm{frag}$ & 1.14 \\
\hline S 40939 & $\mathrm{HH}_{1} \mathrm{~b}$ & $1 \mathrm{frag}$ & 1.12 \\
\hline
\end{tabular}

\section{Avian eggshell - Dinornithiformes, family, genus, species indeterminate}

Avian eggshell, greater than $0.8 \mathrm{~mm}$ thick is rare in the Bannockburn Formation, with most falling in a single thickness class (Table 8). This shell is $0.86-1.14 \mathrm{~mm}$ thick (mean $=1.02 \mathrm{~mm}$, standard error $=0.0269, n=14)$ and is of appropriate size to be from a small moa. It has a mammillary zone of $30 \%$ of the shell thickness in which the mammillae are higher than wide, a well defined squamatic zone of $65 \%$ of the shell thickness with a weakly horizontally aligned structure and a poorly defined external zone that is only $5 \%$ of the shell thickness, at maximum, with a smoothly homogenous structure (Figs 18D \& E). Externally the surface is smooth with slit-like, elongate branching pores (Fig. 18C). This structure is identical to that seen in moa (Aves, Dinornithiformes: Tyler 1957; Tyler \& Simkiss 1960; Zelenitsky \& Modesto 2003) and the thickness is similar to that found in smaller moa taxa (Gill 2000). A single piece is much thicker at $1.68 \mathrm{~mm}$ (Table 8 ) and appears to have a second spongy layer under a distinct external layer. It is unclear whether this is a result of diagenesis or indicates a distinct taxon.

REMARKS. The thicker shell fragments support the contention that moa ancestors were present in the environment about Lake Manuherikia in the Early-Middle Miocene, despite the lack of definitive osseous fossils (although the large bone fragments discussed above could be from moa). The thickness of these egg fragments indicates the presence of a bird as large as the moa Anomalopteryx, which suggests that this presumed moa precursor was already of giant stature and flightless.

\section{DISCUSSION}

\section{The significance of the New Zealand Miocene avifauna}

\section{Procellariiformes}

The diving petrel Pelecanoides miokuaka is by far the oldest representative of the Pelecanoididae known. At 1520 million years old it is the first Miocene record of the family and 10-15 million years older than the previous oldest fossil record for this family in the early Pliocene (Olson 1985a). All four modern petrel (Procellariiformes) families (albatrosses - Diomedeidae; fulmars, gadfly petrels, prions and shearwaters - Procellariidae; stormpetrels - Hydrobatidae; diving petrels - Pelecanoididae) now have a Miocene fossil record (Warham 1996). Olson (1985a) described the Pliocene fossils (from South Africa) as a new species Pelecanoides cymatotrypetes, stating that it 'differs only in minor details from living species of Pelecanoides.' The fact that the well-preserved distal humerus of $P$. miokuaka appears relatively similar to modern taxa and the extinct Pliocene species is little different from modern forms, shows that the family diverged from other Procellariiformes at least by the early Miocene and has maintained a highly stable morphology to the present day. Viot et al. (1993) interpreted molecular data to infer that diving petrels originated as a distinct lineage before the Early Miocene. Penhallurick \& Wink (2004) suggested from molecular data that the extant Pelecanoides species have a common origin no younger than $45.8 \mathrm{Ma}$. Pelecanoides miokuaka certainly indicates the genus existed at about $20 \mathrm{Ma}$.

The finding of a diving petrel at the Miocene lake site suggests that the species was breeding nearby. Petrels are pelagic marine species that only come ashore to nest and do not utilise freshwater bodies (Warham 1996). The probability of finding a petrel bone in a lake deposit seems low, unless there were large numbers of petrels nesting in the land adjacent to the lake. Thus the modern importance of petrels as major contributors of marine nutrients to terrestrial ecosystems (Worthy \& Holdaway 2002) is probably a longstanding feature of New Zealand's history.

\section{Anseriformes}

In Australia, the oldest anatid fossils are known from the late Oligocene-Miocene lacustrine deposits of the Lake Eyre and Tarkarooloo basins of central Australia (Vickers-Rich 1991) but the material remains undescribed. All nine extinct taxa named by de Vis from Pliocene-Pleistocene deposits have been referred to modern taxa by Olson $(1977 b)$ and no other extinct anatids have been described from Australia. No extant taxa are known from pre-Pliocene deposits (Vickers-Rich 1991; T.H.W., pers. obs.).

The most well known ducks of the Lower Miocene of the northern Hemisphere are relatively primitive forms that do not belong in Anas. The early Miocene Dendrochen robusta Miller, 1944 from South Dakota (USA), was made the type genus of Dendrocheninae by Livezey \& Martin (1988). The similarly primitive anatid from North America Anas (=Querquedula) integra (Miller, 1944), also from the Lower Miocene of South Dakota, was transferred to Dendrochen by Cheneval (1987). The unusual swan-sized diver Paranyroca magna Miller \& Compton, 1939, of the early Miocene of South Dakota, was placed in a monotypic family Paranyrocidae by Miller \& Compton (1939) on account of the hypotarsus having only two ridges, but it was later demoted to a subfamily of Anatidae (Brodkorb 1964). However, that this taxon is known only from tarsometatarsi precludes an understanding of its true relationships to other anatids, if indeed it is an anseriform.

In Lower to Middle Miocene sediments from Europe, the most well known anatid is Anas blanchardi MilneEdwards, 1863. Cheneval $(1983,1987)$ recognised that this and associated anatids from Saint-Gérand-le-Puy did not belong in the genus Anas and placed them in the genus Dendrochen. Livezey \& Martin (1988) restudied Anas blanchardi and erected a new genus for it - Mionetta - in the subfamily Dendrocheninae (taxonomically placed after 
Dendrocygninae and before Thalassorninae). Of the two taxa found with $M$. blanchardi, the relatively rare, larger taxon Anas consobrina Milne-Edwards, 1867-71 was considered to be based on large individuals of Mionetta blanchardi, while the smaller Anas natator Milne-Edwards, 1867-71 was transferred to Mionetta (Livezey \& Martin 1988).

Other than these dendrochenines, all Early Miocene anatids fall mainly in the anserine clade. Anserines are represented in the Lower Miocene of Europe by Cygnopterus alphonsi Cheneval, 1984 and Cygnavus senckenbergi Lambrecht, 1931, with both genera having their origin in the Oligocene (Cheneval 1987; Mlíkovský 2002). However, Mlíkovský (2002) synonymised C. alphonsi with C. senckenbergi. Anas robusta Milne-Edwards, 1867-71 (based on a Branta-sized distal humerus from Sansan, France), was placed in Anserobranta? by Cheneval (1987), but later transferred to Mionetta (Mlíkovský 2002). It is not like Mionetta, however, especially in the short distal extent of the flexor process (in which it is most similar to Cygnus), the conformation of the brachial fossa and that the space between the dorsal condyle and the facet for the attachment of the anterior ligament is greater than the width of the facet (Cheneval 1987: pl. 1, fig. 1), not less than as in Dendrocygnini (Woolfenden 1961:6), so we prefer to leave it identified as an anserine in Anserobranta?. The true swans Cygnus, do not appear in Europe until the mid-Miocene, with Cygnus atavus (Fraas, 1870: Mlíkovský 2002), although Lambrecht (1933) considered this taxon should be in Anser. Cygnus appears in North America in the Late Miocene, with Cygnus mariae Bickart, 1990. Geese, such as Anser, appear in the Late Miocene in Europe (Howard 1964) and Anser and Branta both appear in the Late Miocene of North America (Bickart 1990), but are preceded by Presbychen abavus Wetmore, 1930 from the Miocene of California (Howard 1964).

The tadornines are first known with certainty in Europe with the appearance of the genus Tadorna in the early Pliocene in Europe (Mlíkovský 2002). However, an earlier arrival in Europe is possible if Mlíkovský's (2002) referral of Anserobranta tarabukuni Kuročkin \& Ganea, 1972, based on a proximal carpometacarpus from the Late Miocene, to Alopochen is correct. Olson (1985b) reported Tadornini from the Middle Miocene Calvert Formation of Maryland, USA and undescribed fossils similar to Tadorna from the Middle Miocene of Germany. The latter, from the Nördlinger Ries, remain undescribed (P.Ballmann, pers. comm., 24 November 2004). Lambrecht (1933: 368) briefly described Anser scaldii, wrongly attributing it to van Beneden (Mlíkovský 2002: 125), on the basis of a humerus $129 \mathrm{~mm}$ long that he said was like Tadorna casarca, from the middle Miocene of Belgium. We await descriptions of Anser scaldii and the Nördlinger Ries 'tadornid' to see if they represent middle Miocene occurrences of tadornids in Europe.

There are few other genera of anatids recognised from Europe's Early-Middle Miocene. Mlíkovský (2002) erected Oxyura doksana on a cranial end of a left coracoid from the Czech Republic. However, this generic attribution may be in doubt, as the cranial ends of Oxyura coracoids do not differ significantly from those of many anatid genera, including the dendrochenine taxa Mionetta and Manuherikia, and even differ little from those of Anas chlorotis.

In the Anatinae, other than species of 'Anas', there is only the single species Aythya chauvirae Cheneval, 1987 from Sansan, France, based on a femur, but whose type series includes a complete coracoid, a proximal and a distal humerus, a proximal and a distal ulna and distal femur (Cheneval 1987). We note that the holotype, as figured in Cheneval (1987: pl. 1, fig. 7a,b) lacks the lateral expansion of the fibular condyle typical of Aythya. Other than this, a deep popliteal fossa is shared by diving taxa and other taxa, e.g. Malacorhynchus. Of the referred specimens examined by T.H.W. and A.J.D.T., the distal right femur MNHN Sa10279 lacks the fibular condylar area, but the bone has a straight shaft and so lacks the marked ventral bend seen in the distal third of Aythya femora. The proximal end shaft of a right humerus (MNHN Sa10275) has a prominent capital shaft ridge unlike any Aythya. The second referred humeral specimen (MNHN Sa1280), a distal left humerus, is from a considerably smaller bird than MNHN Sa10275, so much so that it is unlikely to be the same taxon. There are no features on this specimen that allow referral to Aythya to the exclusion of other taxa: it is, in contrast, similar to the dendrochenine taxa described herein. Similarly, the referred distal right ulna MNHN Sa1279 lacks features to refer it unambiguously to Aythya. We conclude that Aythya chauvirae Cheneval, 1987 is unlikely to be an Aythya and may well be a dendrochenine and that the hypogeum comprises two taxa.

The species Aythya (=Fuligula) arvernensis (Lydekker, 1891), reported as in need of reassessment by Cheneval (1987), was included in the synonymy of Mionetta blanchardi by Mlíkovský (2002). The taxa Anas velox Milne-Edwards, 1867-71 (whose lectotype is a right carpometacarpus) and Anas sansaniensis Milne-Edwards, 1867-71 (whose lectotype is a distal left tibiotarsus) are both doubtfully correctly placed in Anas (Mlíkovský 2002), a conclusion we agree with as these elements are of insufficient diagnostic utility for generic attribution. The referred coracoid of Anas velox has 'à fosse pneumatique profonde et à bord externe de la facette glénoidale épais' (Cheneval 1987), but it cannot be in the genus Anas because coracoids of Anas lack pneumatic foraminae of any kind within the acrocoracoid, as this description suggests and as is shown in Cheneval (1987: pl. 1, fig. 3). Mlíkovský (2002: 118) synonymised Anas meyerii Milne-Edwards, 1867-71, which Howard (1964) considered indeterminate to genus, with A. velox.

The species Anas oligocaena Tugarinov, 1940 from the upper Oligocene of Siberia, was referred to Dendrochen? by Cheneval (1987). Anas creccoides Beneden, 1871 from the early Oligocene of Belgium is considered indeterminate and relegated to Aves incertae sedis (Brodkorb, 1962: 707). Anas basaltica Bayer, 1882 from the early Oligocene of Czechia is an indeterminate heron (Mlíkovský 2002: 70). Anas skalicensis Bayer, 1882 is based on bones indeterminate at the ordinal level (Mlíkovský 2002: 251). Anas risgoviensis Ammon, 1918 from the Middle Miocene of Germany, is considered as genus incertae sedis by Mlíkovský (2002: 125). Anas isarensis Lambrecht, 1933 (based on a scapula) and Anas eppelsheimensis Lambrecht, 1933 (based on a cranial fragment of a coracoid), both from the late Miocene of Germany, are regarded as Anatidae incertae sedis (Mlíkovský 2002: 124). Anas luederitzensis Lambrecht, 1929 based on a proximal humerus from southwest Africa has a closed ventral pneumotricipital fossa (Howard, 1964), so does not belong in Anas. Therefore, the genus Anas Linnaeus, as now defined e.g. Livezey (1997b), is not certainly known from any time earlier than or in the Miocene. 
The most extensive Lower Miocene anatid fauna known to date was that from Saint-Gérand-Le-Puy (Cheneval 1987). It comprises four species: the dendrochenines Mionetta blanchardi (which includes $M$. consobrina) and $M$. natator, the anserine Cygnopterus alphonsi (Cheneval 1987) and ?Anserobranta robusta (as Mionetta robusta, in Mlíkovský 2002). The mid-Miocene fauna from Sansan also contains four taxa (Cheneval 1987): the anserine?Anserobranta robusta, Aythya chauvirae, which herein we suggest is a possible dendrochenine, and Anas? velox (which includes Anas [=Aythya] meyerii) and Anas? sansaniensis. Cheneval (1987) suggested that the changed taxon composition between these faunas indicated the evolution of anatids from the Lower to mid-Miocene towards a fauna with a modern aspect. This would only be true if the presence of Aythya is confirmed by future analysis.

Recently, Noriega (1995) has described a humerus from the Upper Miocene of Argentina as the first record of the Dendrocheninae in the southern Hemisphere. It lacks the proximal end above the external tuberosity but has the main diagnostic features seen in Manuherikia and at $>92 \mathrm{~mm}$ long with a DW $=12.5 \mathrm{~mm}$, it is a bigger bird than M. lacustrina.

Thus the St Bathans Fauna, with six anatid taxa, is the most diverse Early-Middle Miocene anatid fauna now known. This St Bathans fauna allows some observations on anatid evolution in general. It contains no modern genera of anatids - notably Anas, sensu stricto, is absent, as noted for European faunas by Livezey \& Martin (1988) and data herein. As Anas has not been recorded from sites older than Middle Miocene in Australasia, Europe or North America, it is possible that this genus had yet to evolve. The absence of Cygnus, amid otherwise abundant anatid bones in the St Bathans Fauna, indicates that it was not a member of the Early-Middle Miocene New Zealand avifaunas. Moreover, there is no evidence of Cygnus in Australia until the Pliocene (Vickers-Rich 1991; T.H.W., A.J.D.T., pers obs.), indicating a northern hemisphere origin for swans. In contrast, the presence of Miotadorna in the St Bathans Fauna indicates tadornines have a long history in the Australasian region, possibly predating their appearance in Europe and, therefore, suggesting that tadornines could have evolved in the southern hemisphere. However, as a cautionary note, it is observed that no pre-Pliocene fossil record exists in Australasia for Anseranas (Anseranatidae), the dendrocygnines, the anserines Cereopsis and Cnemiornis and Stictonetta, despite them all being the most primitive members of the Recent fauna (Livezey 1986, 1989, 1996a, 1997b; Worthy et al. 1997), nor is there a pre-Pliocene fossil record for any other extant anatid in the region.

The phylogenetic position of Malacorhynchus has been problematic, with Livezey (1997b) considering the composition of the Tribe Malacorhynchini and its inclusion in Anatinae provisional. Sraml et al. (1996) found that, based on a strict consensus tree of mitochondrial DNA data, Malacorhynchus was the sister taxa to Biziura and close to Dendrocygna. When we examined the skeletal characters of the humerus of both $M$. membranaceus and $M$. scarletti, we found that they both have all the diagnostic features of the Dendrocheninae as given in Livezey \& Martin (1988) and as discussed herein, and differ in no appreciable way. Moreover, the coracoids of Malacorhynchus are very similar to those of Mionetta, especially in the presence of a distinct depression on the ventral surface of the blade (contra Livezey 1996b), also shared with Stictonetta. This indicates support for the primitive location of Malacorhynchus advocated by Sraml et al. (1996). Livezey (1986) found Malacorhynchus to be a highly derived tadornine but in a more extensive analysis (Livezey 1996b) found its placement unresolved. Future analyses of dendrochenine relationships should include Malacorhynchus among compared taxa.

\section{Accipitriformes}

The Quaternary fauna of New Zealand included a large eagle Harpagornis moorei Haast, 1872, in addition to a harrier Circus eylesi Scarlett, 1953 and a falcon Falco novaeseelandiae Gmelin, 1788. It is tempting to speculate that the two fossils reported herein may be from a precursor of Harpagornis, however, they are too incomplete to provide data on this question.

The fossil record of Australia is known to include eagles up to the size of Aquila audax and as old as the late Oligocene-Miocene, from lacustrine deposits in Central Australia (Ngapakaldi and Ngama local faunas) and from Riversleigh in northwestern Queensland (Vickers-Rich 1991), but the material remains undescribed.

Elsewhere in the world, accipitrids have an extensive fossil record dating back to the late Eocene or early Oligocene, with uncontested modern genera appearing first only in the mid-Miocene (Olson 1985b).

\section{Gruiformes}

One of the most distinctive elements of the New Zealand avifauna is the enigmatic gruid Aptornis. Due to extreme specialisation and devolution from a flight capacity, its relationships are obscure and unresolved (e.g. Olson 1985b; Weber \& Hesse 1995; Houde et al. 1997; Livezey 1998). It has obviously been a long-time member of the New Zealand avifauna, but its fossil record until now has been restricted to the late Quaternary and so the report herein of a fossil that may represent an ancestral form is significant. However, a phalanx is not very revealing and we await the discovery of more diagnostic elements that might have bearing on the evolutionary history of this taxon.

The gruiforms in the St Bathans Fauna are otherwise only represented by rallids, as is the case in modern New Zealand. Rail fossils are abundant but fragmentary, nevertheless two taxa are apparent. Both are small: the biggest being the size of a banded rail Gallirallus philippensis. Both appear to be most similar to members of the Gallirallus group, with no evidence of gallinules and coots, which prefer aquatic habitats, so might have been expected as fossils. This contrasts with the modern fauna, where highly derived and endemic gallinules and coots were components of the Recent fauna and several taxa had evolved to become among the largest of their kind in the world, e.g. Fulica prisca Hamilton, 1893, F. chathamica Forbes, 1892b, Porphyrio mantelli (Owen, 1848), P. hochstetteri (A.B. Meyer, 1883). A surprising aspect of the Early Miocene fauna is the observation that the most abundant rail species present was apparently flightless and markedly sexually dimorphic in size. The flightless taxon indicates that flightless rails were a feature of both the Miocene and Recent faunas of New Zealand (Worthy \& Holdaway 2002).

Olson (1985b) described the Tertiary record of rails as meagre and largely uninformative, with the first referred taxa to the family dating from the lower Eocene, but all based on 
fragmentary isolated bones. Not until the upper OligoceneEarly Miocene from deposits in France, are there taxa known from adequate diagnostic material, e.g. Rallicrex Lambrecht, Palaeoaramides Lambrecht, Paraortygometra Lambrecht, but these lack modern analysis and their relationships remain undetermined, despite having morphologies not significantly different from modern rallids (Olson 1985b). Recently Mayr \& Smith (2001) described two species in the new genus Belgirallus from the early Oligocene of Belgium, while Fischer (1997) described Rupelrallus from the early Oligocene of Germany. From continental deposits younger than mid-Miocene, all rallid material has been assigned to modern genera (Olson 1985b).

In Australia, rails occur in late Oligocene-Early Miocene beds in central Australia (Ngapakaldi and Ngama local faunas) and at Riversleigh (Vickers-Rich 1991). A flightless gallinule has been recently described by Boles (2005) from the Oligo-Miocene of Riversleigh, but the other Tertiary forms remain undescribed. The New Zealand record thus complements others but we await more complete material for more adequate comparisons and diagnoses.

\section{Charadriiformes}

Boev (2000) reported a gull (Larinae, genus indet.) from the Lower Miocene of western Bulgaria and summarised the fossil record of the group. Larus elegans Milne-Edwards, 1867-71 [1868] and Larus totanoides Milne-Edwards, 186771 [1868] (both from the late Oligocene-Early Miocene of France and transferred to the new genus Laricola by Mlíkovský (2002)), are the oldest undisputed gull taxa, if it is accepted that Larus desnoyersii Milne-Edwards, 1863, has closer affinity to Stercorariidae (Olson 1985b). Larus raemdonckii Beneden, 1871 (from the lower Oligocene of Belgium), was transferred to Puffinus. Larus dolnicensis Švec, 1980, as noted by Olson (1985b), is not a gull and was transferred to Mioglareola in the Glareolidae (Mlíkovský 2002). Larus pristinus Shufeldt, 1915 is from the Lower Miocene of Oregon, but Olson (1985b) considered the generic attribution doubtful. However, Gaviota niobrara Miller \& Sibley, 1941 is a larid from the mid-Miocene of Nebraska (Olson 1985b) and Olson \& Rasmussen (2001) recorded Larus sp. from the Middle Miocene Pungo River Formation. Thus gulls do have a wide, though sparse, distribution in the Lower-Middle Miocene and could be expected in New Zealand.

There are many fossils named and unnamed attributed to Charadriiformes (Olson 1985b; Mlíkovský 2002). If the very small taxon reported here is a Calidris sandpiper, it would compliment an Early Miocene record of the genus (Mlíkovský 2002). The family Charadriidae is reported from two European Miocene records but the genus Charadrius itself has only a Pliocene-Recent distribution in Europe (Mlíkovský 2002). Several other small waders, described from the Early-Middle Miocene of Europe (Totanus lartetianus Milne-Edwards, 1863; T. grivensis Ennouchi, 1930; T. majori Lydekker, 1893; T. minor Ennouchi, 1930 and Tringa gracilis Milne-Edwards, 1867-71 [1868]), are all considered genus incertae sedis by Mlíkovský (2002), but indicate a diversity of waders at this time. Most recently, Ballmann (2004) has erected four new species within the new genus Mirolia, which was referred to Calidridinae, from the Nördlinger Ries of the Middle Miocene in Germany. Charadriiforms of up to Miocene age are known from Australia (Vickers-Rich 1991: 760) but none have been distinguished at family level yet. Ballmann (2004) considered that entire elements representing several parts of the post cranial skeleton and cranial elements were needed to evaluate subfamilial affinities and in the absence of, especially, whole humeri and other diagnostic remains, the New Zealand fossils certainly cannot yet be assigned to subfamily or genera.

\section{Columbiformes}

Pigeons and doves have a fossil record in Australia extending back to the late Oligocene-Early Miocene, from lacustrine deposits at Lake Palankarinna (Etadunna Formation) and Lake Pinpa (Namba Formation) of central Australia (Vickers-Rich 1991) but the material is undescribed. Elsewhere in the world, the fossil record of columbids is meagre (Olson 1985b; Becker \& Brodkorb 1992). The fossil Columba calcaria Milne-Edwards 1867-1871, from the Lower Miocene at Saint-Gérand-le-Puy in France, is now considered to be a sandgrouse (Pteroclididae), as Gerandia calcaria (Mlíkovský 2002). An abundant small dove from the Thomas Farm Local Fauna, Early Miocene 18-19 Ma, of Florida (Olson 1985b) has been recently described in a modern genus, as Columbina prattae Becker \& Brodkorb (1992). Australasia has about 30 breeding species (including three recently extinct) in 15 genera (Higgins \& Davies 1996; Holdaway et al. 2001). Considering this diversity and the early fossil record in Australia, an Early Miocene New Zealand record of Columbidae is not unexpected, but the relationships of the fossil will remain obscure until better material is available.

\section{Psittaciformes}

Parrots have an old fossil record in Europe, with stemgroup representatives (including Pseudasturidae) present in the Lower Eocene (Olson 1985b; Dyke \& Cooper 2000; Mayr 2001, 2002b). Crown-group taxa first appear in Lower Miocene European sites, with Archaeopsittacus verreauxi (Milne-Edwards 1867-1871) the best known of a variety of taxa (Olson 1985b; Mayr \& Göhlich 2004). From the Miocene of North America, there is a single taxon described (Olson 1985b; Mayr \& Göhlich 2004).

Fossil parrots are rare in the Australian Tertiary (Vickers-Rich 1991), despite the proliferation of taxa in the Recent fauna. The oldest Australian record is of Cacatuidae from the Early Miocene or late Oligocene deposits at Riversleigh (Boles 1993a).

\section{Aegotheliformes}

Aegothelids, in the form of Quipollornis koniberi VickersRich \& McEvey, 1977, have a mid-Tertiary fossil record in Australia, dated to 13.5-17 Ma (Vickers-Rich \& McEvey 1977; Vickers-Rich 1991). The ten Recent species of $A e$ gotheles occur in the Australasian region from the Maluku Islands (1 sp.), through Papua New Guinea (7 spp.), Australia (A. cristatus), New Caledonia (A. savesi) and (recently extinct) in New Zealand (A. novaezealandiae (Scarlett, 1968)). Mitochondrial DNA studies indicate that the group is monophyletic, with $A$. savesi and A. novaezealandiae being weakly associated as sister taxa and together are the most primitive members of the group and are not sister taxa to A. cristatus, as geography might lead one to infer (Dumbacher et al. 2003). 
An aegothelid from the Lower-Middle Miocene of New Zealand indicates a long history of the group in New Zealand, as could have been predicted from the distant phylogenetic relationship between A. novaezealandiae and A. savesi, its closest relative, and other taxa (Dumbacher et al. 2003).

\section{Apodidae}

Swifts are unknown as breeding taxa in New Zealand, so the Miocene fossil adds a novel (presumably breeding) bird family to the country's past fauna.

Boles (2001) described Collocalia buday from late Oligocene to ?Early-Middle Miocene deposits at Riversleigh, northwestern Queensland. This taxon, based on three humeri, a tarsometatarsus and a coracoid, was larger than other compared Collocalia species and is the oldest record of the family Apodidae in Australia and of Collocaliini in the world.

The presence of a Collocalia species in New Zealand about the same time is thus not unexpected. Also, its presence supports the postulated subtropical-tropical environment indicated by palaeofloral studies (Pole \& Douglas 1998; Pole et al. 2003), as Collocalia (26 species, including Aerodramus as a synonym), is now a member of tropical faunas from Southeast Asia, through the Philippines, Indonesia, Melanesia, northern Australia and Oceania as far as the Marquesas (Higgins 1999; Steadman 2002).

\section{Passeriformes}

Little can be said about the passerine record of the St Bathans Fauna at this stage, other than to note that at least three species were present. There is no fossil evidence yet for the New Zealand endemic families Acanthisittidae, Turnagridae and Calleatidae in the Miocene. The only fossil that can so far be associated with any taxon, is a scapula which we consider to be very similar to that of currawongs and Australian magpies. These are members of the Australian Cracticidae, although the introduced Australian magpie is a familiar member of the current New Zealand avifauna.

\section{Notable absences}

At the present time there is no evidence in the St Bathans Fauna for other waterbirds such as grebes (Podicepidae) and flamingos (Phoenicopteridae and Palaelodidae), despite a late Oligocene-Miocene record for these groups in Australia (Vickers-Rich 1991). Anhingids, despite being a member of the Recent Australian fauna, lack a pre-Pliocene fossil record there (Vickers-Rich 1991) and as yet have not been found in the St Bathans fauna. Cormorants (Phalacrocoracidae) have a Miocene record in Australia from undescribed material (Vickers-Rich 1991), but are another notable absence, contra Peat (2002), from the St Bathans Fauna considering their high diversity in the Recent fauna of New Zealand. There is also no evidence in the St Bathans Fauna for herons (Ardeidae), storks (Ciconiidae), or ibises and spoonbills (Threskiornithidae), which is as expected since these groups are absent in pre-Pliocene deposits in Australia (Vickers-Rich 1991).

\section{Worldwide significance of the New Zealand Miocene fauna}

The St Bathans Fauna includes the first terrestrial avifauna of Tertiary age described for New Zealand. The comprehensive review by Fordyce (1991) showed that the New Zealand avian fossil record included mainly penguins (Sphenisciformes) with a few bony-toothed birds (Pelagornithidae). Fordyce (1991) reported undescribed anatids from near St Bathans in the Manuherikia Group that were discovered by Barry Douglas and Jon Lindqvist in 1980 (Douglas et al. 1981; Douglas 1986). A few other Middle-Late Miocene aged bones were reported from freshwater limestone deposits in the Waitaki Valley (Fordyce 1991), but like the Manuherikia bones, they remained undescribed. The large moas (Aves: Dinornithiformes) only have a fossil record extending to 2.5 million years ago (Worthy et al. 1991). In contrast to this poor Tertiary record, the late Quaternary record is extraordinarily rich (Worthy \& Holdaway 2002).

The Manuherikia Group sediments (16-19 Ma, Altonian, Early-Middle Miocene) were deposited shortly after much of New Zealand re-emerged from an Oligocene marine transgression. Maximum coverage of the land occurred in the Oligocene-earliest Miocene when perhaps only $18 \%$ of the present land area remained (Cooper \& Cooper 1995). With the onset of renewed tectonism and lowering sea level in the Early Miocene, land area rapidly increased thereafter. The Oligocene transgression was postulated to be a time of evolutionary stress on the fauna, a bottleneck, during which diversity of terrestrial biota would have been markedly reduced (Cooper \& Cooper 1995) and mitochondrial DNA evidence for moas, kiwis (Apterygidae) and wrens (Acanthisittidae), has provided evidence for radiations in these groups since the Miocene. Cooper \& Cooper (1995) and Campbell \& Landis (2001) further suggested that the Oligocene transgression was the reason that terrestrial mammals and snakes are not now present in New Zealand, noting that they may have been present once. Such reasoning applies to other groups such as the Chelidae turtles and the lungfishes (Ceratodontidae).

If this scenario is correct, then an Early Miocene fauna in New Zealand should reflect one recently released from ecological constraint and may be one of restricted diversity, or one having close affinity to Australian faunas, assuming dispersal of taxa from that continent enabled colonisation of a depauperate land. However, as this initial investigation of the avifauna reveals, there is no lack of diversity indicated, with five genera and six species of waterfowl, at least, and a wide range of other bird families represented. This St Bathans Fauna shows few similarities to similar-aged Australian faunas in terms of faunal composition. There, bird faunas were dominated by the mihirungs Dromornithidae (Murray \& Vickers-Rich 2004) casuariids, common flamingos, palaelodids and anatids, as well as by rarer megapodiids, charadriiforms (including Burhinidae), pelicans, falconiforms, gruiforms, columbids, psittaciforms and passeriforms (Vickers-Rich 1991; Boles 1993a, b, 1995; Boles \& Ivison 1999). Some taxa are common to both regions: Pelecanoides, Aegotheles, Collocalia and Cracticidae, but among the common waterfowl of the St Bathans Fauna, there are no described Australian equivalents and we have seen none among undescribed material. Among vertebrates in the Manuherikia Group St Bathans Fauna, birds dominate unquestionably, and do so in groups known today, but there were several bats, skinks and geckos, sphenodontids and a crocodilian. Except for the crocodilian and the sphenodontitid to remind us of the ancient gondwanan connection, the overall impression is that by Manuherikian time, the fauna had acquired its Recent bird-dominated New Zealand character - the St Bathans Fauna already had a distinctive 
Table 9 Summary of taxa from the St Bathans Fauna.

\begin{tabular}{|c|c|c|c|c|c|}
\hline Family & Genus & Species & Croc Site L1 & $\mathrm{HH}_{1 \mathrm{a}}$ & $\mathrm{HH}_{2}$ \\
\hline ?Dinornithidae & Genus indet. & Sp. indet. & $Y$ & $\mathrm{Y}$ & \\
\hline Pelecanoididae & Pelecanoides & miokuaka & $\mathrm{Y}$ & & \\
\hline \multirow[t]{6}{*}{ Anatidae } & Manuherikia & lacustrina & $\mathrm{Y}$ & $\mathrm{Y}$ & Y \\
\hline & & minuta & $Y$ & $Y$ & $Y$ \\
\hline & Miotadorna & sanctibathansi & $\mathrm{Y}$ & $\mathrm{Y}$ & \\
\hline & Dunstanetta & johnstoneorum & & & $Y$ \\
\hline & Matanas & enrighti & Y & $\mathrm{Y}$ & \\
\hline & Genus indet. & Sp. indet. & & $Y$ & \\
\hline Accipitridae & Genus indet. & Sp. indet. & $\mathrm{Y}$ & & $\mathrm{Y}$ \\
\hline ?Aptornithidae & Genus indet. & Sp. indet. & & $\mathrm{Y}$ & \\
\hline \multirow[t]{2}{*}{ Rallidae } & Genus indet. & Sp. indet. 1 & $\mathrm{Y}$ & $\mathrm{Y}$ & $\mathrm{Y}$ \\
\hline & & Sp. indet. 2 & & $\mathrm{Y}$ & \\
\hline Laridae & Genus indet. & Sp. indet. & $Y$ & $Y$ & \\
\hline \multirow[t]{2}{*}{ ‘wader’ } & Genus indet. & Sp. indet. 1 & $\mathrm{Y}$ & & \\
\hline & & Sp. indet. 2 & Y & $Y$ & \\
\hline Columbidae & Genus indet. & Sp. indet. & & Y & \\
\hline \multirow[t]{3}{*}{ Psittacidae } & Genus indet. & Sp. indet. 1 & Y & $\mathrm{Y}$ & \\
\hline & & Sp. indet. 2 & & $Y$ & \\
\hline & & Sp. indet. 3 & Y & & \\
\hline Aegothelidae & Aegotheles & Sp. indet. & & $\mathrm{Y}$ & \\
\hline Apodidae & Collocalia & Sp. indet. & & $Y$ & \\
\hline \multirow[t]{3}{*}{ Passeriforms } & Cracticidae, Genus indet. & Sp. indet. 1 & Y & & \\
\hline & Genus indet. & Sp. indet. 2 & $Y$ & & \\
\hline & & Sp. indet. 3 & $Y$ & $Y$ & \\
\hline
\end{tabular}

Abbreviations: Sp., species; indet., indeterminate; Y, yes.

New Zealand flavour to it. Therefore, it is evident that a diverse terrestrial vertebrate fauna passed through the postulated Oligocene bottleneck and certainly there is no evidence to support the theory of a complete drowning of proto-New Zealand during this period of high sea levels, as suggested by Campbell \& Landis (2001). The presence of a crocodilian, the swiftlet Collocalia sp., and probable abundant parrots, are in keeping with a subtropical environment reconstructed from macro- and microfloral studies (Pole et al. 2003).

\section{CONCLUSION}

In the subtropical environs of the Lower-Middle Miocene Lake Manuherikia, waterfowl dominated the avifauna, with at least six species in five genera (Table 9). Tadornines perhaps ancestral to Tadorna, were present, but there were no modern genera and no anserines. Other modern waterbirds, such as shags and grebes would have been expected in the fossil fauna but were apparently absent. Living in the surrounding habitats were two diminutive rails (one of which was flightless) and at least one large gruid (perhaps a forerunner to Aptornis), but there is no evidence yet for herons, ibises, flamingos or storks. Other fossil birds included several parrots, an owlet nightjar, a swiftlet and a range of passerines, including a currawong-like species. There is no evidence yet for the presence of any of the Recent endemic passerine families. Aerial predators included a medium-sized accipitrid, but there is no evidence yet for owls or falcons. The absence of several other bird families from the fossil fauna (such as kiwis, kingfishers, cuckoos), may be due to preservational biases (e.g. few small arboreal bird species are represented) or may reflect what were natural rarities around
Lake Manuherikia and it should not be taken as evidence of the absence of these taxa from the Miocene of New Zealand. Moas were probably present but are only represented by eggshell and possibly by bone fragments to date. However, these indicate that moas were large, presumably flightless, birds in the Early-Middle Miocene. Lastly, as in modern New Zealand, petrels were present, with a diving petrel Pelecanoides miokuaka presumed to be nesting near Lake Manuherikia. New Zealand at last has a non-marine midTertiary avifauna.

\section{ACKNOWLEDGEMENTS}

We are particularly grateful to the landowners Jack Enright and Ann and Euan Johnstone for access to the sites on their land. We are especially indebted to Euan who greatly aided the excavations by using his digger to remove overburden. We are indebted for the help of Rex Austin, Travis Cross, Rachael Ines, Dave Matthews, Euan Johnstone, Paul Scofield, and Jamie Wood during excavations and Jenny Jones and Barney Tennyson for sorting sediment. We thank Storrs Olson and Paul Scofield for helpful comments on drafts of the text, Mike O'Neill (Te Papa) for photography and Dave Roscoe for photographic help.

We thank the following people for access to comparative material: Paul Scofield, Canterbury Museum, Christchurch; Walter Boles, Australian Museum, Sydney, Australia; Storrs Olson and Brian Schmidt, USNM, Washington DC, USA; Robert Palmer, Australian National Wildlife Collection, Canberra, Australia; Joanne Cooper, Natural History Museum (Tring), United Kingdom; Cecile Mourer-Chauviré, Universite Claude Bernard, Lyon 1, Centre des Sciences de 
la Terre, Villeurbanne Cedex, France; Estelle Bourdon, Museum National d'Histoire Naturelle, Paris; and especially Walter Boles and Brian Schmidt for providing images of certain specimens. We thank Gerald Mayr for comments that improved the text and Gerald Mayr, Walter Boles and Paul Scofield for help with references.

This research was supported by funding to T.H.W. from the Public Good Science Fund of the New Zealand Foundation for Research, Science and Technology, under contract TWOX0201.

\section{ReferenCES}

Amadon, D. 1943. Birds collected during the Whitney South Sea Expedition. 52. Notes on some non-passerine genera, 3. American Museum Novitates 1237: 1-22.

Ammon, L. von 1918. Tertiäre Vogelreste von Regensburg und die jungmiozäne Vogelwelt. Abhandlungen des Naturwissenschaftlichen Vereines in Regensberg 12: 1-70.

Ballmann, P. 2004. Fossil Calidridinae (Aves: Charadriiformes) from the Middle Miocene of the Nördlinger Ries. Bonner Zoologische Beiträge 52: 101-114.

Baumel, J. J. \& Witmer, L. M. 1993. Osteologia. Pp. 45-132, figs 4.14.18 in J. J. Baumel, A. S. King, J. E. Breazile, H. E. Evans, \& J. C. Vanden Berge (eds) Handbook of avian anatomy: Nomina anatomica avium (2nd edition). Publications of the Nuttall Ornithological Club, volume 23, Cambridge, Massachusetts, USA.

Bayer, F. 1882. O nových zbytcích zkamenĕlých ptáku z českého útvaru třetihorního [On new remains of fossil birds from the Czech Tertiary system.] Vesmír 12: 20-21.

Becker, J. J. \& Brodkorb, P. 1992. An early Miocene ground dove (Aves: Columbidae) from Florida. Pp. 189-193 in K. E. Campbell (ed.) Papers in Avian Paleontology honoring Pierce Brodkorb. Natural History Museum of Los Angeles County, Science Series, No. 36, Los Angeles.

Beneden, P. J. van 1871. Les oiseaux de l'argille rupélienne. Bulletins de l'Académie Royalle des Sciences, Lettres et des Beaux-Arts de Belgique (2) 32: 256-261. [Pagination of the offprint is 213-218].

- 1875. Un oiseau fossile nouveau des caverns de la Nouvelle Zélande. Annales de la Société Géologique de Belgique 2: 123-130, pl. 3.

Bickart, K. J. 1990. The birds of the Late Miocene-Early Pliocene Big Sandy Formation, Mohave County, Arizona. Ornithological Monographs No. 44: 1-72.

Bock, W. J. 1994. History and nomenclature of avian family-group names. Bulletin of the American Museum of Natural History 222: 1-281.

Boev, Z. 2000. A Lower Miocene gull (Larinae gen. indet.) (Laridae Vigors, 1825 - Charadriiformes Huxley, 1867) from Hrabarsko (W Bulgaria). Geologica Balanica 30(1-2): 25-31.

Boles, W. E. 1993a. A new cockatoo (Psittaciformes: Cacatuidae) from the Tertiary of Riversleigh, northwestern Queensland, and an evaluation of rostral characters in the systematics of parrots. Ibis 135: 818.

- 1993b. A logrunner Orthonyx (Passeriformes: Orthonychidae) from the Miocene of Riversleigh, northwestern Queensland. Ети 93: 44-49.

- 1995. A preliminary analysis of the Passeriformes from Riversleigh, Northern Queensland, Australia, with a description of a new species of Lyrebird. Courier Forschungsinstitut Senckenberg 181: 163-170.

- 2001. A swiftlet (Apodidae: Collocaliini) from the Oligo-Miocene of Riversleigh, northwestern Queensland. Memoir of the Association of Australasian Palaeontologists 25: 45-52.

- 2005. A new flightless gallinule (Aves: Rallidae: Gallinula) from the Oligo-Miocene of Riversleigh, northwestern Queensland, Australia. Records of the Australian Museum 57: 179-190.

- \& Ivison, T. J. 1999. A new genus of the dwarf megapode (Galliformes: Megapodiidae) from the late Oligocene of Central Australia. Proceedings of the 4th International meeting of the Soci- ety of Avian Paleontology and Evolution. Washington, USA, June 1996. Smithsonian Contributions to Paleobiology 89: 199-206.

Bonaparte, C. L. 1838. Geographical and comparative list of the birds of Europe and North America. John van Voorst, London, 67 pp.

- 1853. Classification ornithologique par series. Comptes Rendus des Séances de l'Académie des Sciences (Paris) 37: 641-647.

- 1854. Conspectus systematicus ornithologiae. Annales des sciences naturelles/Zoologie (4) 1: 105-152.

- 1856. Additions et corrections au coup d'oeil sur l'ordre des pigeons, et à la partie correspondante du Conspectus Avium. Comptes Rendus Hebdomadaires des Séances de l'Académie des Sciences (Paris) 43 833-841.

Brodkorb, P. 1962. The systematic position of two Oligocene birds from Belgium. Auk 79: 706-707.

- 1964. Catalogue of fossil birds. Part 2 (Anseriformes through Galliformes). Bulletin of the Florida State Museum, Biological Sciences 8 195-335.

Campbell, H. \& Landis, C. 2001. New Zealand awash. New Zealand Geographic 51: 6-7.

Cheneval, J. 1983. Les Anatidae (Aves, Anseriformes) du gisement Aquitanien de Saint-Gérand-le-Puy (Allier, France). Pp. 85-97 in E. Buffetaut, J. M. Mazin \& E. Salmon (eds) Actes du Symposium Paléontologique Georges Cuvier, Montbéliard, France, 1982. Ville de Montbéliard edit, Montbéliard, France.

- 1984. Les oiseaux aquatiques (Gaviiformes à Anseriformes) du gisement aquitanien de Sait-Gérand-le-Puy (Allier, France). Révision Systematique. Palaeovertebrata, Montpellier 14 (fasc. 2): 33-115, 6 figs, 13 tab., 9 pl.

- 1987. Les Anatidae (Aves, Anseriformes) du Miocene de France. Révision Systématique et évolution. Pp. 137-157 in C. MourerChauviré (ed.) L'Évolution des Oiseaux d'Après le Temoignage des Fossils. Documents du Laboratoire Geologique de Lyon, volume 99, Lyon, France.

Cooper, A. J. \& Cooper, R. A. 1995. The Oligocene bottleneck and New Zealand biota: genetic record of a past environmental crisis. Proceedings of the Royal Society of London Series B 261: 293-302.

Cooper, R. A. \& Millener, P. R. 1993. The New Zealand biota: historical background and new research. Trends in Ecology and Evolution $\mathbf{8}$ 429-433.

Dickinson, E. C. (ed.) 2003. The Howard and Moore complete checklist of the birds of the world (3rd Edn). Christophe Helm, London, 1039 pp.

Donne-Goussé, C., Laudet, V. \& Hänni, C. 2002. A molecular phylogeny of anseriformes based on mitochondrial DNA analysis. Molecular Phylogenetics and Evolution 23: 339-356.

Douglas, B. J. 1986. Lignite resources of Central Otago. Manuherikia Group of Central Otago, New Zealand: stratigraphy, depositional systems, lignite resource assessment and exploration models. New Zealand Energy Research and Development Committee Publication, 2 vols, $104 \mathrm{pp}$

—, Lindqvist, J. K., Fordyce, R. E. \& Campbell, J. D. 1981. Early Miocene terrestrial vertebrates from Central Otago. Geological Society of New Zealand newsletter 53: 17.

Dyke, G. J. \& Cooper, J. H. 2000. A new Psittaciform bird from the London Clay (Lower Eocene) of England. Palaeontology 43: 271285.

Dumbacher, J. P., Pratt, T. K. \& Fleischer, R. C. 2003. Phylogeny of the owlet-nightjars (Aves: Aegothelidae) based on mitochondrial DNA sequence. Molecular Phylogenetics and Evolution 29: 540-549.

Elliot, D. G. 1870. Descriptions of some new genera and species of birds belonging to the families Formacariidae, Pachycephalidae, and Sylviidae. Proceedings of the Zoological Society of London $\mathbf{1 8 7 0}$ (Pt II): 242-244.

Ennouchi, E. 1930. Contribution à l'étude de la faune du Tortonien de La Grive-Saint-Alban (Isère). Presses Modernes, Paris, 135 pp.

Eyton, T. C. 1838. A monograph on the Anatidae, or Duck Tribe. Longmans, London, $\mathrm{x}+178 \mathrm{pp}$.

Fischer, K. 1997. Neue Vogelfunde aus dem mittleren Oligozään des Weißelsterbeckens bei Leipzig (Sachsen). Mauritiana 16: 271-288. 
Flower, B. P. \& Kennett, J. P. 1994. The middle Miocene climatic transition: East Antarctic ice shelf development, deep ocean circulation and global carbon cycling. Palaeogeography, Palaeoclimatology, Palaeoecology 108: 537-555.

Forbes, H. O. 1892a. New extinct rail [Telegram]. Nature 45: 252.

$-1892 b$ (March). On a recent discovery of the remains of extinct birds in New Zealand. Nature 45(1166): 416-418.

Fordyce, R. E. 1991. A new look at the fossil vertebrate record of New Zealand. Pp. 1191-1316 in P. V. Rich, J. M. Monaghan, R. F. Baird, T. H. Rich, (eds) Vertebrate palaeontology of Australasia. Pioneer Design Studios in cooperation with the Monash University Publications Committee, Melbourne, $1437 \mathrm{pp}$.

- 2003. Fossils and the history of life. Pp. 35-64 in J. Darby, R. E. Fordyce, A. Mark, K. Probert \& C. Townsend (eds) The natural history of Southern New Zealand. Otago University Press, Dunedin, NZ, $387 \mathrm{pp}$.

- \& Jones, C. M. 1990. Penguin history and new fossil material from New Zealand. Pp. 419-446 in J. Darby (ed.) Penguin biology. Academic Press, San Diego.

Fraas, O. 1870. Die fauna von Steinheim. Mit Rücksicht auf die miocänen Säugethier - und Vogelreste des Steinheimer Beckens. Jahreshefte des Vereins für Vaterländische Naturkunde in Württemberg 26: 145-306. [Republished in Stuttgart by E. Schweizerbart'sche Verglagshandlung, 1870].

Fürbringer, M. 1888. Untersuchungen zur Morphologie und systematik der Vögel. Zugleich ein Beitrag zur Anatomie de Stütz- und Bewegungsorgune. 2 vol., 1751 pp., 30 pl. T. J. Van Holkema, Amsterdam.

Gill, B. J. 2000. Morphometrics of moa eggshell fragments (Aves: Dinornithiformes) from Late Holocene dune-sands of the Karikari Peninsula, New Zealand. Journal of the Royal Society of New Zealand 30: 131145.

Gmelin, J. F. 1788. Systema Naturae per Regna Tria Naturae, secundum classes, ordines, genera, species, cum characteribus, differentiis, synonymis, locis. Tomus I. Linné, editio decima tertia, aucta, reformata. Regnum Animalium, pt 1. G. E. Beer, Leipzig, (Lipsiae), pp. 1-500.

- 1789. Systema Naturae per Regna Tria Naturae, secundum classes, ordines, genera, species, cum characteribus, differentiis, synomymis, locis. Tomus I. Linné, editio decima tertia, aucta, reformata. Regnum Animalium, pt 2. G. E. Beer, Leipzig (Lipsiae), pp. 501-1032.

Gould, J. 1837. Untitled [ = 'Mr. Gould resumed the exhibition of his collection of Australian birds, and also several species from the same country, forming portions of the collections of the United Services Museum, and the King's College, London.'] Proceedings of the Zoological Society of London 1837: 24-27.

- 1841. Untitled [ = 'Mr. Gould completed the exhibition of his fifty new species of Australian birds.... '] Proceedings of the Zoological Society of London 1840: 169-178.

- 1850. A brief account of the researches in natural history of John McGillivray, Esq., the naturalist attached to H. M. surveying ship the Rattlesnake, on the north-eastern coasts of Australia, New Guinea \&c. Contributions to Ornithology (Jardine) 1850: 92-106.

- 1856. On new species of birds (Nestor notabilis and Spatula variegata) from the collection of Walter Mantell. Proceedings of the Zoological Society of London 1856: 94-95.

Gray, G. R. 1840. A List of the Genera of Birds, with an indication of the typical species of each genus. R. \& J. E. Taylor, London, viii +80 pp.

- 1843. In E. Dieffenbach (ed.) Travels in New Zealand, 2 vols. John Murray, London.

- 1871. Hand-list of genera and species of birds, distinguishing those contained in the British Museum Part III. Struthiones, Grallae, and Anseres, with Indices of Genera and Specific Names. British Museum, London.

Gray, J. E. 1830. Illustrations of Indian Zoology chiefly selected from the collection of Maj.-Gen. Hardwicke. Vol. 1, Part 2. Treuttel, Wurtz, Treuttel, Jun. and Richter, London.

Haast, J. 1872. Notes on Harpagornis moorei, an extinct gigantic bird of prey, containing description of femur, ungual phalanges, and rib. Transactions and Proceedings of the New Zealand Institute 4: 192196.
Hamilton, A. 1893. On the fissures and caves at the Castle Rocks, Southland; with a description of the remains of the existing and extinct birds found in them. Transactions and Proceedings of the New Zealand Institute 25: 88-106.

Hartert, E. 1892. Podargidae. In Catalogue of the Birds in the British Museum. Catalogue of the Picariae. Coraciae. British Museum, London, vol. 16, xvi +703 pp., 14 pls.

Higgins, P. J. (ed.) 1999. Handbook of Australian, New Zealand and Antarctic birds. Volume 4: Parrots to Dollarbird. Oxford University Press, Melbourne, $1248 \mathrm{pp}$.

— \& Davies, S. J. J. F. (eds) 1996. Handbook of Australian, New Zealand \& Antarctic birds, vol. 3 - Snipe to Pigeons. Oxford University Press, Melbourne, $1028 \mathrm{pp}$.

Holdaway, R. N., Worthy, T. H. \& Tennyson, A. J. D. 2001. A working list of breeding bird species of the New Zealand region at first human contact. New Zealand Journal of Zoology 28(2): 119-187.

Horsfield, T. 1840. List of Mammalia and birds collected in Assam by John McClelland. Proceedings of the Zoological Society of London 1839: 146-167.

Howard, H. 1929. The avifauna of Emeryville Shellmound. University of California Publications in Zoology 32(2): 301-394.

Howard, H. 1964. Chapter 10: Fossil Anseriformes. Pp. 233-326 in J. Delacour (ed.) The Waterfowl of the World. Country Life Ltd, London, $364 \mathrm{pp}$.

Houde, P., Cooper, A., Leslie, E., Shand, A. E. \& Montano, G. A. 1997. Phylogeny and evolution of $12 \mathrm{~S}$ rDNA in gruiformes (Aves). Pp. 117154 in D. P. Mindell (ed.) Avian molecular evolution and systematics. Academic Press, San Diego, 382 pp.

Hume, A. O. 1873. [Novelties? Collocalia innominata, Sp. Nov.] Stray Feathers 1: 294-297.

- 1878. In Hume A. O. \& Davison W. (eds) A revised list of the birds of Tenasserim. Stray Feathers 6: 1-524.

Hutton, F. W. 1871. Catalogue of the birds of New Zealand with diagnoses of the species. Geological Survey of New Zealand, Wellington, $\mathrm{x}+$ $85 \mathrm{pp}$.

- 1872. Notes on some birds from the Chatham Islands collected by H. H. Travers, Esq.; with descriptions of two new species. Ibis (series 3) 2: 243-250.

Huxley, T. H. 1867. On the classification of birds; and on the taxonomic value of the modifications of certain cranial bones observable in that class. Proceedings of the Zoological Society of London 1867 (Pt II): 415-472.

Illiger, J. K. W. 1811. Prodromus systematis Mammalium et Avium additis terminis zoographicis utriusque classis, eorumque versonie germanica. C. Salfeld, Berlin, xviii +301 pp.

Jardine, W. \& Selby, P. J. 1827. Illustrations of Ornithology Volume 1, Pt II, pls 17-32, W. H. Lizars, Edinburgh.

$-\&-1828$. Illustrations of Ornithology Volume 1, Pt IV, pl. 62 W. H. Lizars, Edinburgh.

Johnsgard, P. A. 1968. Waterfowl: Their biology and natural history. University of Nebraska Press, Lincoln, Nebraska.

Kuročkin, E. N. \& Ganea, I. M. 1972. Pticy srednego sarmata Moldavii [Birds of the middle Sarmatian of Moldova.]. Pp. 45-70 in A. I. David (ed.) Pozvonočnye neogena i plejstocena Moldavii [Vertebrates of the Neogene and Pleistocene of Moldova]. Ştiinca, Chişinău.

Lacépède, B. G. E. de la V. 1799. Tableau des divisions, sous-divisions, ordres et genres des Mammifères. Supplement to Discours d' ouverture et de clôture du cours d'histoire naturelle donné dans le Muséum National d'Histoire Naturelle, l'an VII de la République, et tableau méthodiques des mammifères et de oiseaux. Plassan, Paris, France, $18 \mathrm{pp}$.

Lambrecht, K. 1929. Stromeria fajumensis n. g. n. sp., die kontinentale Stammform der Aepyornithidae, mit einer Ubersicht über die fossilen Vögel Madagaskars und Afrikas. Abhandlungen der Bayerischen Akademie der Wissenschaften. Mathematisch-Naturwissenschaftliche Abteilung. München 4 (art. 4): 1-18.

- 1931. Cygnopterus und Cygnavus, zwei fossile Schwäne aus dem Tertiär Europuas. Bulletin du Musée Royal d'Histoire Naturelle de Belgique 7(31): 1-6. 
— 1933. Handbuch der Palaeornithologie. Gebrüder, Borntraeger, Berlin, $1024 \mathrm{pp}$.

Layard, E. L. \& Layard, E. L. C. 1881. Notes on the avifauna of New Caledonia and the New Hebrides. With remarks by the Rev. Canon Tristan. Ibis 5 (4th Series) 17: 132-139.

Latham, J. 1790. Index Ornithologicus, sive systema ornithologia: complectens Avium divisionem in classes, ordines, genera, species, ipsarumque varietates. Vol. 1. Leigh \& Sotherby, London, xviii + $920 \mathrm{pp}$.

- 1802. Index Ornithologicus, sive systema ornithologia: complectens Avium divisionem in classes, ordines, genera, species, ipsarumque varietates. Supplementum, \&c. Leigh \& Sotherby, London, xxiv pp.

Leach, W. E. 1820. Eleventh room. Pp. 65-70 in Synopsis of the contents of the British Museum 17th Edition. British Museum, London, [See Bock 1994 for description].

Lear, E. 1831. Illustrations of the family of Psittacidae, or parrots: the greater part of them species hitherto unfigured. Pt 4. E. Lear, London, viii pp., 42 pls.

Lesson, R. P. 1828. Manuel d' Ornithologie, ou Description des Genres et des Principales Espèces d'Oiseaux. Vol 2. Roret, Paris.

- 1830. Traite d'Ornithologie, ou Tableau Methodique des Orders, SousOrders, Familles, Tribus, Genres, Sous-Generes et Races d'Oiseaux. Vol. 4. F. G. Levrault, Paris.

- 1831. Traite d'Ornithologie. ou Tableau Methodique des Orders, SousOrders, Familles, Tribus, Genres, Sous-Generes et Races d'Oiseaux. Vol. 6. F. G. Levrault, Paris.

- \& Garnott, P. 1826. Description de quelques nouvelles espèces de oiseaux (Mainatus Mino, Gracula religiosa, G. calva, Mainatus Dumontii, etc.) recueillies dan l'expédition de découverte commandée par la Capitaine Duperrey. Ferussac's Bulletin des Sciences Naturelles et de Geologie 8: 158-160.

Lichtenstein, H. 1823. Verzeichniss der Doubletten des zoologischen Museums der Königl. Universität zu Berlin nebst Beschreibung vieler bisher unbekannter Arten von Säugethieren, Vögelin, Amphibien und Fischen. Königl Universität, Berlin, $\mathrm{x}+118$ pp.

Linnaeus, C. 1758. Systema Naturae per Regna Tria Naturae, 10th Edition, revised, Vol 1: Regnum Animale. Salvii, L. Holmiae, Stockholm, Sweden, iv $+824 \mathrm{pp}$.

- 1766. Systema Naturae per Regna Tria Naturae, secundum classes, ordines, genera, species, cum characteribus, differentiis, synonymis, locis. Editio duodecima, reformata. Holmiae, Laurentii Salvii, Stockholm, Vol. 1, 1327 \& 36 pp.

Livezey, B. C. 1986. A phylogenetic analysis of Recent anseriform genera using morphological characters. Auk 105: 681-698.

- 1989. Phylogenetic relationships of several subfossil anseriformes of New Zealand. Occasional papers of the Museum of Natural History of the University of Kansas 128: 1-25.

- 1991. A phylogenetic analysis and classification of Recent dabbling ducks (Tribe Anatini) based on comparative morphology. Auk 108: 471-507.

- 1996a. A phylogenetic analysis of geese and swans (Anseriformes: Anserinae), including selected fossil species. Systematic Biology $\mathbf{4 5}$ 415-450.

- 1996b. A phylogenetic reassessment of the tadornine-anatine divergence (Aves: Anseriformes: Anatidae). Annals of the Carnegie Museum 65: 27-88.

- 1997a. A phylogenetic analysis of modern shelducks and sheldgeese (Anatidae: Tadornini). Ibis 139: 51-66.

- 1997b. A phylogenetic classification of waterfowl (Aves: Anseriformes), including selected fossil species. Annals of the Carnegie Museum 67: 457-496.

- 1998. A phylogenetic analysis of the Gruiformes (Aves) based on morphological characters, with an emphasis on the rails (Rallidae). Philosophical Transactions: Biological Sciences (B) 353 (1378): 20772151.

- 2003. Evolution of flightlessness in rails (Gruiformes: Rallidae): phylogenetic, ecomorphological, and ontogenetic perspectives. Ornithological Monographs No. 53. The American Ornithologists' Union, Washington, DC, $654 \mathrm{pp}$
— \& Martin, L. D. 1988. The systematic position of the Miocene anatid Anas [?] blanchardi Milne- Edwards. Journal of Vertebrate Paleonto$\operatorname{logy}$ 8(2): 196-211.

Lorenz, L. v. 1896. Vortrag Ueber die Nestor - Papageien. Verhandlungen der Zoologisch - botanischen Gesellschaft in Wien 46: 197199.

Lydekker, R. 1891. Catalogue of fossil birds in the British Museum (Natural History). British Museum (Natural History), London 368 pp.

- 1893. On some bird-bones from the Miocene of Grive-St-Alban, Department of Isere, France. Proceedings of the Zoological Society of London 1893: 517-522.

Mathews, G. M. 1910-1911. Birds Australia 1: Witherby \& Co, London, xiv $+301 \mathrm{pp}$.

- 1912-1913. Birds Australia 2: Witherby \& Co, London, xi + 527 pp.

Marchant, S. \& Higgins, P. J. (co-ordinators) 1990. Handbook of Australian, New Zealand \& Antarctic birds, vol. 1, Ratites to Ducks. Oxford University Press, Melbourne, 1400 pp.

Mayr, G. 2001. Comments on the systematic position of the putative Lower Eocene parrot Pulchrapollia gracilis. Senckenbergiana Lethaea 81: $339-341$

$-2002 a$. Osteological evidence for paraphyly of the avian order Caprimulgiformes (night-jars and allies). Journal für Ornithologie 143: 8297.

- 2002b. On the osteology and phylogenetic affinities of the Pseudasturidae - Lower Eocene stem-group representatives of parrots (Aves, Psittaciformes). Zoological Journal of the Linnean Society 136: 715729.

- 2003. Phylogeny of early Tertiary swifts and hummingbirds (Aves: Apodiformes). Auk 120: 145-151.

— \& Göhlich, U. B. 2004. A new parrot from the Miocene of Germany, with comments on the variation of hypotarsus morphology in some Psittaciformes. Belgium Journal of Zoology 134: 47-54.

— \& Smith, R. 2001. Ducks, rails, and limicoline waders (Aves: Anseriformes, Gruiformes, Charadriiformes) from the lowermost Oligocene of Belgium. Geobios 34: 547-561.

Meyer, A. B. 1883. Abbildungen von Vogel-Skeletten, Herausgegebin mit Unterstutzung der Generaldirection der Königl. Sammlungen für Kunst und Wissenschaft in Berlin and Dresden, vol. 1: xiv + $71 \mathrm{pp}$; vol. 2 : xxi + 120 pp., 122 pls.

Mildenhall, D. C. 1989. Summary of the age and palaeoecology of the Miocene Manuherikia Group, Central Otago, New Zealand. Journal of the Royal Society of New Zealand 19: 19-29.

— \& Pocknall, D. T. 1989. Miocene-Pleistocene spores and pollen from Central Otago, South island, New Zealand. New Zealand Geological Survey Palaeontological Bulletin 59: 1-128.

Miller, A. H. 1944. An avifauna from the lower Miocene of South Dakota. University of California Publications, Bulletin of the Department of geological Sciences 27: 85-100.

- \& Compton, L. V. 1939. Two fossil birds from the Lower Miocene of South Dakota. Condor 41: 153-156.

— \& Sibley, C. G. 1941. A Miocene gull from Nebraska. Auk 58: $563-$ 566.

Milne-Edwards, A. 1863. Mémoire sur la distribution géologique des oiseaux fossils et description de quelques especies nouvelles. Annales des Sciences Naturelles 4(20): 132-176. [Abbreviated versions in Bulletin de la Sociétié Philomatique 1863: 61-64; Comptes Rendus des Séances Hebdomadaires de l' Académie des Sciences (Paris) 56: 1219_ 1222; Revue des Sociétés Savantes (1)4: 1-5.]

- 1867-71. Recherches anatomiques et paléontologiques pour server à l'historie des oiseaux fossils de la France. Masson, Paris, vol $\mathbf{1}$, 472 pp., 96 pl; vol. 2, 627 pp., pl. 97-200.

Mlíkovský, J. 2002. Cenozoic birds of the World, Part 1: Europe. Ninox Press, Praha, 406 pp.

Molnar, R. E. \& Pole, M. 1997. A Miocene crocodilian from New Zealand. Alcheringa 21: 65-70.

— \& Wiffen, J. 1994. Polar dinosaur faunas from New Zealand. Cretaceous Research 15: 689-706.

Murphy, R. C. \& Harper, F. 1916. Two new diving petrels. Bulletin of the American Museum of Natural History 35: 65-67. 
Murray, P. F. \& Vickers-Rich, P. 2004. Magnificent mihirungs, the colossal flightless birds of the Australian dreamtime. Indiana University Press, Bloomington and Indianapolis, $410 \mathrm{pp}$.

Noriega, J. I. 1995. The avifauna from the "Mesopotamian" (Ituzaingó Formation, Upper Miocene) of Entre Rios Province, Argentina. Courier Forschungsinstitut Senckenberg 181: 141-148.

Olphe-Gaillard, V. A. L. 1887. Contributions à la fauna ornithologique de l'Europe occidentale. Lassere, Bayonne.

Olson, S. L. 1973. A classification of the Rallidae. The Wilson Bulletin 85: 381-416.

- 1977a. Notes on the subfossil Anatidae from New Zealand, including a new species of pink-eared duck Malacorhynchus. The Ети 77: 123135.

- 1977b. The identity of the fossil ducks described from Australia by C. W. De Vis. The Eтu 77: 127-135.

- 1985a. Early Pliocene Procellariiformes (Aves) from Langebaanweg, south-western Cape Province, South Africa. Annals of the South African Museum 95: 123-145.

- 1985b. The fossil record of birds. Pp. 79-256 in D. S. Farner, J. R. King \& K. C. Parkes (eds) Avian biology, vol. 8. Academic Press, New York.

- \& Rasmussen, P. C. 2001. Miocene and Pliocene birds from the Lee Creek Mine, North Carolina. Smithsonian Contributions to Paleobio$\operatorname{logy}$ 90: 233-365.

Oustalet, J. F. E. 1878. Description de quelques espèces nouvelles de la Cochinchine et de la Nouvelle-Guinée. Bulletin des Sciences par la Societe Philomatique (7) 2: 50-59.

Owen, R. 1844. On Dinornis, an extinct genus of tridactyle struthious birds, with descriptions of portions of the skeleton of five species which formerly existed in New Zealand. (Part I). Transactions of the Zoological Society of London III(3): 235-275, pl. 18-30.

- 1848. On Dinornis (Part III): containing a description of the skull and beak of that genus, and of the same characteristic parts of Palapteryx, and of two other genera of birds, Notornis and Nestor; forming part of an extensive collection of ornithic remains discovered by Mr Walter Mantell at Waingongoro, North Island of New Zealand. Transactions of the Zoological Society of London III(5): 345-378, pl. 52-56.

Pallas, P. S. 1776. Reise durch verschiedene Provinzen des Russischen Reichs 3. Gedruckt bey der Kayserlichen Academie der Wissenschaften, St Petersburg.

Peale, T. R. 1848. United States Exploring Expedition. During the years 1838, 1839, 1840,1841, 1842. Under the command of Charles Wilkes, U. S. N. Vol. VIII, Mammalia and Ornithology. C. Sherman, Philadelphia. xxv + 338 pp. 21 figs.

Paykull, G. de. 1815. Lanii crassirostris, avis antea ignotae descriptio. Nova Acta Regiae Societatis Scientiarum Upsaliensis 7: 282-285, Tab. $\mathrm{X}$, Uppsala.

Peat, N. 2002. Southern Land, Southern People: Otago Museum's Landmark Gallery. University of Otago Press, Dunedin.

Penhallurick, J. \& Wink, M. 2004. Analysis of the taxonomy and nomenclature of the Procellariiformes based on complete nucleotide sequences of the mitochondrial cytochrome $b$ gene. The Ети 104: 125147.

Pole, M. 1989. Early Miocene floras from Central Otago, New Zealand. Journal of the Royal Society of New Zealand 19: 121-125.

- 1992a. Early Miocene flora of the Manuherikia Group, New Zealand. 1. Ferns. Journal of the Royal Society of New Zealand 22: 279-286.

- 1992b. Early Miocene flora of the Manuherikia Group, New Zealand. 2. Conifers. Journal of the Royal Society of New Zealand 22: 287302.

- 1992c. Early Miocene flora of the Manuherikia Group, New Zealand. 3. Possible cycad. Journal of the Royal Society of New Zealand 22 : 303-306.

- 1993a. Early Miocene flora of the Manuherikia Group, New Zealand. 4. Palm remains. Journal of the Royal Society of New Zealand $\mathbf{2 3}$ 283-288.

- 1993b. Early Miocene flora of the Manuherikia Group, New Zealand. 5. Smilacaceae, Polygonaceae, Elaeocarpaceae. Journal of the Royal Society of New Zealand 23: 289-302.
- 1993c. Early Miocene flora of the Manuherikia Group, New Zealand. 6. Lauraceae. Journal of the Royal Society of New Zealand 23: 303-312.

- 1993d. Early Miocene flora of the Manuherikia Group, New Zealand. 7. Myrtaceae. Journal of the Royal Society of New Zealand 23: 313-328.

- 1993e. Early Miocene flora of the Manuherikia Group, New Zealand. 8. Nothofagus. Journal of the Royal Society of New Zealand 23: 329-344.

- 1993f. Early Miocene flora of the Manuherikia Group, New Zealand. 9. Miscellaneous leaves and reproductive structures. Journal of the Royal Society of New Zealand 23: 345-391.

— 1993g. Early Miocene floras of the Manuherikia Group, New Zealand. 10. Paleoecology and stratigraphy. Journal of the Royal Society of New Zealand 23: 393-426.

- 1997. Miocene conifers from the Manuherikia Group, New Zealand. Journal of the Royal Society of New Zealand 27: 355-370.

- \& Douglas, B. 1998. A quantitative palynostratigraphy of the Miocene Manuherikia Group, New Zealand. Journal of the Royal Society of New Zealand 28: 405-420.

-, Douglas, B. \& Mason, G. 2003. The terrestrial Miocene biota of southern New Zealand. Journal of the Royal Society of New Zealand 33: 415-426.

Rafinesque, C. S. 1815. Analyse de la nature, ou tableau de l'univers et des corps organisés. Published privately, Palermo, Italy. [Reprinted Auk 26: 37-55.]

Reichenbach, H. G. L. 1849-1850. Die Vollständigste Naturgeschichte des In- und Austlandes, Abteilung II. Vogel, Band I. Expedition der Vollständigsten Naturgeschichte, Dresden, Germany.

Rothschild, W. 1893. [Rallus muelleri, sp. n.] Bulletin of the British Ornithologists Club 1(8): 40-41.

Salvin, O. 1896. Catalogue of the birds in the British Museum, Volume $X X V$. British Museum, London.

Sangster, G. 2005. A name for the clade formed by owlet-nightjars, swifts and hummingbirds (Aves). Zootaxa 799: 1-6.

Scarlett, R. J. 1953. A sub-fossil hawk from New Zealand. Records of the Canterbury Museum 6: 2345-252.

- 1968. An owlet-nightjar from New Zealand. Notornis 15(4): 254266.

Schodde, R. \& Mason, I. J. 1999. The directory of Australian birds. A taxonomic and zoogeographic atlas of the biodiversity of birds in Australia and its territories. Passerines. CSIRO Publishing, Collingwood, Victoria, Australia.

Shaw, G. 1790. In White J. Journal of a voyage to New South Wales with... plates of non-descript animals, birds, lizards, serpents, curious cones of trees and other natural productions: (A Diary of Winds, \&c.), J. Debrett, London, xv + 299 pp., 65 pls.

Shufeldt, R. W. 1915. Fossil birds in the Marsh collection of Yale University. Transactions of the Connecticut Academy of Arts and Sciences 19: $1-109$.

Sibley, C. G. \& Ahlquist, J. E. 1981. The phylogeny and relationships of the ratite birds as indicated by DNA-DNA hybridization. Pp. 301-335 in G. G. E. Scudder \& J. L. Reveal (eds) Evolution today. CarnegieMellon University, Pittsburg.

Simonetta, A. M. 1967. Cinesi e morfologia del cranio negli Ucelli non passeriformi. Studio su varie tendenze evolative. Part II - Striges, Caprimulgiformes ed Apodiformes. Archive Zoologico Italiano 52: $1-35$.

Sparrman, A. 1786. Museum Carlsonianum, in quo novas et selectas aves, coloribus ad vivum brevique descriptione illustratas, suasu et sumtibus generosissimi possessoris. fasc. 1. Holmiae, Stockholm.

Sraml, M., Christidis, L., Easteal, S., Horn, P. \& Collet, C. 1996. Molecular relationships within Australasian waterfowl (Anseriformes). Australian Journal of Zoology 44: 47-58.

Steadman, D. W. 2002. A new species of swiftlet (Aves: Apodidae) from the Late Quaternary of Mangaia, Cook Islands, Oceania. Journal of Vertebrate Paleontology 22: 326-331.

Stresemann, E. 1914. Was ist Collocalia fuciphaga (Thunb.)? Verhandlungen der Ornithologische Gesellschaft in Bayern 12: 1-12. 
Sutherland, R. 1999. Basement geology and tectonic development of the greater New Zealand region: an interpretation from regional magnetic data. Tectonophysics 308: 341-362.

Švec, P. 1980. Lower Miocene birds from Dolnice (Cheb Basin), western Bohemia. Časopsis pro Mineralogii a Geologii 25: 377-387.

Temminck, C. J. 1821. Account of some new species of birds of the genera Psittacus and Columba, in the Museum of the Linnean Society. Transactions of the Linnaean Society of London 13: 107-130.

- 1826. In C. J. Temminck \& M. Laugier de Chartrouse (eds) Nouveau Recueil de Planches Coloriées d'Oiseaux. G. Lavrault, Paris.

Tugarinov, A. Ja. 1940. Novye dannye dlja treticnoj ornitofauny SSSR [New data on the Tertiary avifauna of USSR.] Doklady Akademii Nauk SSSR 26: 205-208, 314-316.

Turbott, E. G. (Convener) 1990. Checklist of the birds of New Zealand and the Ross Dependency, Antarctica. Third Edition. Ornithological Society of New Zealand, Inc., Random Century, Auckland, New Zealand, $x v+247 \mathrm{pp}$.

Tyler, C. 1957. Some chemical, physical and structural properties of moa egg shells. Journal of the Polynesian Society 66: 110-130.

- \& Simkiss, K. 1960. A study of the eggshells of ratite birds. Proceedings of the Zoological Society of London 133: 201-243.

Vickers-Rich, P. 1991. The Mesozoic and Tertiary history of birds of the Australian plate. Pp. 721-808 in P. V. Rich, J. M. Monaghan, R. F. Baird \& T. H. Rich (eds) Vertebrate palaeontology of Australasia. Pioneer Design Studio and Monash University Publications Committee, Melbourne.

- \& McEvey, A. 1977. A new owlet-nightjar from the Early to midMiocene of eastern New South Wales. Memoirs National Museum Victoria 38: 247-253.

Viellot, L. J. P. 1816. Analyse d' une nouvelle ornithology elementaire. Déterville, Paris, 70 pp.

- 1817. Nouveau Dictionnaire d'Histoire Naturelle. Nouvelle edition, vol. 8. Déterville, Paris.

- 1819. Nouveau Dictionnaire d'Histoire Naturelle. Nouvelle edition, vol. 28. Déterville, Paris.

Vigors, N. A. 1824. Sketches in ornithology; or, observations on the leading affinities of some of the more extensive groups of birds. On the groups of the Falconidae. Zoological Journal 1: 308-346.

- \& Horsfield, T. 1827. A description of the Australian birds in the collection of the Linnean Society; with an attempt at arranging them according to their natural affinities. Transactions of the Linnaean Society of London 15: 170-331.

Viot, C. R., Jouventin, P. \& Bried, J. 1993. Population genetics of southern seabirds. Marine Ornithology 21: 1-25.

Wagler, J. G. 1827. Systema Avium. Part 1. J. Cottae, Stuttgart and Tübergin, $411 \mathrm{pp}$.

- 1831. Einige Mittheilungen über Thiere Mexicos. Isis von Oken $\mathbf{5}$ : 510-535.

Warham, J. 1996. The behaviour, population biology and physiology of the petrels. Academic Press, London.
Weber, E. \& Hesse, A. 1995. The systematic position of Aptornis, a flightless bird from New Zealand. Courier Forschunginstitut Senckenberg 181: 293-301.

Wetmore, A. 1930. Fossil bird remains from the Temblor formation near Bakersfield, California. Proceedings of the California Academy of Sciences 19(8): 85-93.

Woolfenden, G. E. 1961. Postcranial osteology of the waterfowl. Bulletin of the Florida State Museum (Biol. Sci.) 6: 1-129.

Worthy, T. H. 1995. Description of some post-cranial bones of Malacorhynchus scarletti, a large extinct pink-eared duck from New Zealand. The Ети 95: 13-22.

- 1997. A mid-Pleistocene rail from New Zealand. Alcheringa 21: 7178

- 2002. The New Zealand musk duck (Biziura delautouri Forbes 1892). Notornis 49: 19-28.

- 2004a. The Holocene fossil waterfowl fauna of Lake Poukawa, North Island, New Zealand. Tuhinga 15: 77-120.

- 2004b. The fossil rails (Aves: Rallidae) of Fiji with descriptions of a new genus and species. Journal of the Royal Society of New Zealand 34: 295-314.

-2005. A new species of Oxyura (Aves: Anatidae) from the New Zealand Holocene. Memoirs of the Queensland Museum 51: 255-272.

- \& Gill, B. J. 2002. New distributional records of the extinct New Zealand duck Malacorhynchus scarletti (Anatidae). Records of the Auckland Museum 39: 49-52.

- \& Holdaway, R. N. 2002. The lost world of the moa: Prehistoric life of New Zealand. Indiana University Press, Bloomington and Indianapolis, Indiana, xxiii $+718 \mathrm{pp}$.

- \& Olson, S. L. 2002. Relationships, adaptations, and habits of the extinct duck 'Euryanas' finschi. Notornis 49: 1-17.

—, Edwards, A. R. \& Millener, P. R. 1991. The fossil record of moas (Aves: Dinornithiformes) older than the Otira (last) Glaciation. Journal of the Royal Society of New Zealand 21: 101-118.

—, Holdaway, R. N., Sorenson, M. D. \& Cooper, A. C. 1997. Description of the first complete skeleton of the extinct New Zealand goose Cnemiornis calcitrans Owen, (Aves: Anatidae), and a reassessment of the relationships of Cnemiornis. Journal of Zoology, London 243: 695-723.

-, Tennyson, A. J. D., Jones, C. \& McNamara, J. A. 2002a. A diverse Early-Miocene (15-20 Ma) terrestrial fauna from New Zealand reveals snakes and mammals. IPC2002, Geological Society of Australia Abstracts 68: 174-175.

- , - - \& - 2002b. The Early-Miocene (15-20 Ma) Manuherikia Group reveals New Zealand's first diverse Tertiary terrestrial fauna. Pp. 58 in H. R. Grenfell (ed.) Abstracts and Programme. Geological Society of New Zealand Annual Conference, "Northland 2002". Geological Society of New Zealand Miscellaneous Publication no. 112A.

Zelenitsky, D. K. \& Modesto, S.P. 2003. New information on the eggshell of ratites (Aves) and its phylogenetic implications. Canadian Journal of Zoology 81: 962-970. 